\title{
A STUDY OF FACULTY RESEARCH PRODUCTIVITY
}

\author{
A Dissertation \\ Presented to \\ The Faculty of the Curry School of Education \\ University of Virginia
}

\author{
In Partial Fulfillment \\ of the Requirements for the Degree \\ Doctor of Education
}

by

Theresa Gaye Frazier Bailey

B.S.Mus.Ed., M.Ed.

January 6,1992 
Source of Data: The Carnegle Foundation for the Advancement of Teaching, 1989 National Survey of Faculty s.

(C) Copyright by Theresa Gaye Frazier Bailey

Al I Rights Reserved January, 1992 
The Department of Educational Leadership and Poll dy Studies Center for the Study of Higher Education

Curry School of Education

University of Virginia

Charlottesville, Virgin la

APPROVAL OF THE DISSERTATION

This dissertation, A STUDY OF FACULTY RESEARCH PRODUCTIVITY, has been approved by the Graduate Faculty of the Curry School of Education in partial fulfillment of the requirements for the degree of Doctor of Education.
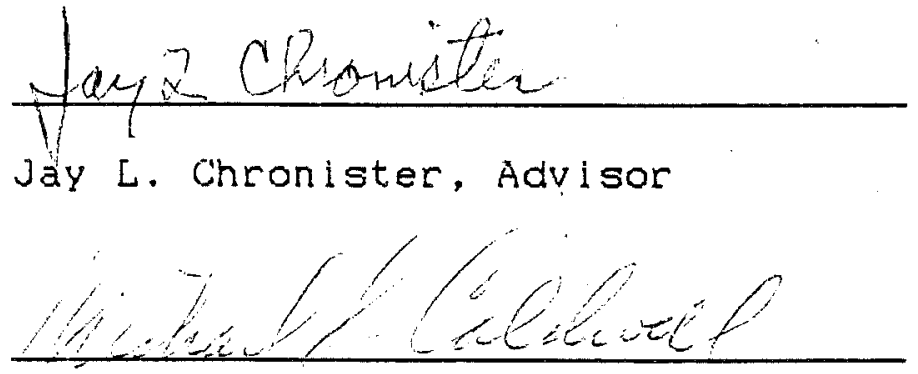

Michael S. Caldwell

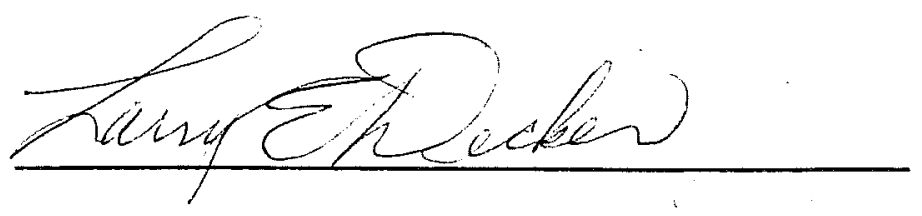

Larry E. Decker

Bette gibbs

Annette Gibbs

Deere, 18, $197 !$ Date 
ABSTRACT

A STUDY OF EACULTY RESEARCH PRODUCTIVITY

Theresa G. Bail ley

University of Virginia

Major Advisor: Dr. Jay L. Chronister

The purpose of this study was to examine the relationship between and among factors that have been identified in the literature to explain the variance in faculty research performance--psychologicalindividual factors, cumulative advantage, reintorcement, and disciplinary norms. No study had previously incorporated the four explanations for variance in taculty research productivity in a single study.

In order to investigate this problem, the researcher utilized self-report data from the 1989 Carnegie Survey of faculty. Individual research performance of 4380 full-time, tenured and non-tenured faculty employed in Research Universities, Doctorate Granting Universities, Comprehensive Colleges and Universities, and Liberal Arts Colleges was studied by 
eight correlates of faculty research productiyity. These research correlates were institutional affiliation, academic rank, discipline, tenure status, gender, the number of hours per week spent on research and or scholarly activities, current engagement in scholarly work, and receipt of internal research support in the past twelve months. Four types of publication counts and the receipt of external research support were used as measures of research performance. Data analysis relied on descriptive statistics and stepwise multiple regression techniques.

Results of this study indicated rank and institutional affiliation were significant predictors ( $p \leq .1)$ for each of the five measures of taculty research productivity. Current engagement in scholarly work, tenure status, and the hours per week spent on research andror scholarly activities were significant predictors $(p \leq .1)$ for four of the flve measures of research productivity. Overall, levels of faculty scholarly productivity increased from Liberal Arts II Colleges through Research I Universities, the rank of 
instructor through the rank of professor, non-tenured to tenured faculty, females to males, nonrecelpt of internal research support to receipt of such support, no engagement in scholarly work to engagement in such activity, and spending ten or less hours per week on researchischolarly activities through spending forty hours per week on such activities. Engineering faculty were the most productive in four of the flve measures of research performance. Faculty in the Biological Sciences ranked second on three of the five measures of scholarly performance and Fine Arts faculty ranked last on three of the $f$ ive research measures. 
To My Family

\author{
Terry \\ Scott \\ Terry Lynn \\ and my parents
}

Charles Scott ("Bus") and Eula Trent Frazler 


\section{ACKNOWLEDGEMENTS}

With gratitude, I express my appreciation to my advisor, Dr. Jay L. Chronister, and my committee members, Dr. Michael Caldwell, Dr. Larry Decker, and Dr. Annette Gibbs, for their guidance and encouragement during my doctoral program.

Special thanks are extended to many friends who provided assistance and reassurance:

To Eileen Wllliams, for her computer programming expertise.

To Janet Coiner, for reading the dissertation and providing editorial comments.

To my colleagues and students at Liberty University, for their interest and encouragement in my doctoral studies.

To my husband, Terry, for his consultation, moral support, and model.

To my chlldren, Scott and Terry Lynn, for their patlence, understanding, and encouragement.

To my parents, for their example and love.

And to my Creator, for His strength and presence in my life. 
Table of Contents

Abstract . . . . . . . . . . . . . . . . 1

Dedication................. . . iv

Acknow ledgements . . . . . . . . . . . . . . .

Table of Contents................. . . . . .

List of Tables................... . ix

Chapter 1 - Introduction to the Study . . . . . . . . 1

Purpose of the study . . . . . . . . . . . 5

Rationale for the Study............7

Research Questions............. . 11

Chapter 2 - Review of the Related Iiterature..... 13

Historlcal Development of the Research Role for Faculty... . . . . . . . . . . . 14

Philosophical Context of Faculty Research Role. . 19

Correlates of Faculty Research Productivity. . . .22

Scholarly Productivity Model. . . . . . . . 38 
Table of Contents

continued

Chapter 3 - Design and Methods . . . . . . . . 40

Research Questions . . . . . . . . . . . .42

Research Model. . . . . . . . . . . . 44

Definition of Terms . . . . . . . . . . 48

The Study Group . . . . . . . . . . . . 50

The Instrument . . . . . . . . . . . 56

Data Analysis . . . . . . . . . . . . 56

Limitations . . . . . . . . . . 60

Chapter 4 - Results . . . . . . . . . . .63

Research Measures by Institutional Type . . . . 65

Research Measures by Rank . . . . . . . . . 73

Research Measures by Discipline... . . . 79

Research Measures by Tenure Status . . . . . . 89

Research Measures by Gender . . . . . . . 94

Research Measures by Hours Spent on Research . . .99

Research Measures by Current Engagement. . . .104

Research Measures by Internal Research Support . 109

Hours Spent on Research by Research Correlates . 114 


\section{Table of Contents continued}

Faculty Engagement by Research Correlates . . . 122 Internal Research Support by Research Correlates.131 Levels of Faculty Research Productivity. . . . .138 Multiple Regression . . . . . . . . . . . 139

Chapter 5 - Summary and Discussion . . . . . . .147 References . . . . . . . . . . . . . . . 165 Appendices . . . . . . . . . . . . . . . . 185

Cover Letter and Carnegie Survey Questionnaire . 186 Demographic Summaries . . . . . . . . . . 198 


\section{LIST OF TABLES}

Table

Page

1 Mean No. Articles in Academic or Professional Journals by Institutional Type . . . . . . 66

2 Mean No. Articles in Edited Collections or Volumes by Institutional Type . . . . . . . .67

3 Mean No. Books or Monographs Publ ished or Edited Alone or in Collaboration by Institutional Type . . . . . . . . . . 69

4 Mean No. Professional Writings Published or Accepted for Publication in the Past Two Years by Institutional Type . . . . . . . .70

5 Percentage of Faculty Who Received External Research Support in the Past Twelve Months by Institutional Type . . . . . . . . . . 71

6 Mean No. Articles in Academic or Professional Journals by Academic Rank . . . . . . . . 73

7 Mean No. Articles in Edited Collections or Volumes by Academic Rank. . . . . . . . 74

8 Mean No. Books or Monographs Publ lshed or Edited Alone or in Collaboration by Academic Rank. . . . . . . . . . . . . . 75

9 Mean No. Professional Writings Published or Accepted for Publication in the Past Two Years by Academic Rank . . . . . . . . . 77

10 Percentage of Faculty Who Received External Research Support in the Past Twelve Months by Academlc Rank . . . . . . . . . . . . 78

11 Mean No. Artlcles in Academic or Professional Journals by Discipline . . . . . . . . . 80

12 Mean No. Articles in Edited Collections or Volumes by Discipline . . . . . . . . . . . 81 


\section{List of Tables \\ cont inued}

Table

Page

13 Mean No. Books or Monographs Publ ished or

Edited Alone or in Collaboration by

Discipline.

14 Mean No. Professional Writings Published or

Accepted for Publication in the Past Two

Years by Discipline. . . . . . . . . . . 85

15 Percentage of Faculty Who Recelved External

Research Support by Discipline . . . . . . 86

16 Mean No. Articles in Academic or Professional

Journals by Tenure Status . . . . . . . . . 89

17 Mean No. Articles in Edited Collections or

Volumes by Tenure Status . . . . . . . . 90

18 Mean No. Books or Monographs Published or Edited

Alone or in Collaboration by Tenure Status. . 91

19 Mean No. Professional Writings Published or

Accepted for Publication in the Past Two

Years by Tenure Status . . . . . . . . . 92

20 Percentage of Faculty Who Received External

Research Support by Tenure Status . . . . . .93

21 Mean No. Articles in Academic or Professional

Journals by Gender . . . . . . . . . . . 94

22 Mean No. Articles in Edited Collections or

Volumes by Gender . . . . . . . . . . . 95

23 Mean No. Books or Monographs Published or Edited

Alone or in Collaboration by Gender. . . . . .96

24 Mean No. Professional Writings Published or

Accepted for Publication in the Past Two

Years by Gender. . . . . . . . . . . . . 97

25 Percentage of Faculty Who Received External

Research Support by Gender . . . . . . . . 9 98 


\author{
List of Tables \\ cont inued
}

Table

Page

26 Mean No. Articles in Academic or Professional Journals by Hours Spent Per Week on Research and or Scholarly Activities... . . . . . . . 99

27 Mean No. Articles in Edited Collectlons or Volumes by Hours Spent Per Week on Research and or Scholarly Activities... . . . . 100

28 Mean No. Books or Monographs Published or Edited Alone or in Collaboration by Hours Spent Per Week on Research and or Scholarly Activities .101

29 Mean No. Professional Writings Published or Accepted for Publication in the Past Two Years by Hours Spent Per Week on Research and or Scholarly Activitles. . . . . . . 102

30 Percentage of Faculty Who Received External

Research Support by Hours Spent Per Week on

Research and or Scholarly Activitles... . . 103

31 Mean No. Articles in Academic or Professional Journals by Current Engagement in Scholarly Work...................104

32 Mean No. Articles in Edited Collections or Volumes by Engagement in Scholarly Work . . . 105

33 Mean No. Books or Monographs Publ Ished or Edlted Alone or in Collaboration by Engagement in Scholarly Work . . . . . . . 106

34 Mean No. Professional Writings Published or Accepted for Publication in the Past Two Years by Engagement in Scholarly Work . . . 107

35 Percentage of Faculty Who Recelved External Research Support by Engagement in Scholarly

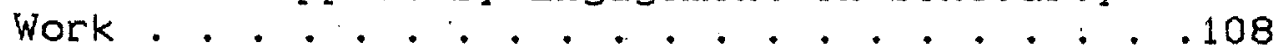

36 Mean No. Articles in Academic or Professional Journals by Receipt of Internal Research Support................ . . 110 


\section{List of Tables \\ continued}

Table

Page

37 Mean No. Articles in Edited Collections or

Volumes by Receipt of Internal Research

Support................ . . 110

38 Mean No. Books or Monographs Publlshed or Edited

Alone or in Collaboration by Receipt of

Internal Research Support. . . . . . . . 111

39 Mean No. Professional Writings Published or

Accepted for Publication in the Past Two

Years by Recelpt of Internal Research

Support.................. . 112

40 Percentage of Faculty Who Received External

Research Support by Receipt of Internal

Research Support. . . . . . . . . . . . .113

41 Mean Hours/Week Spent on Research/Scholarly

Actlvity by Institutional Type . . . . . . .115

42 Mean Hours/Week Spent on Research/Scholarly

Activity by Gender . . . . . . . . . . . . .116

43 Mean Hours/Week Spent on Research/Scholarly

Activity by Tenure Status . . . . . . . . 117

44 Mean Hours/Week Spent on Research/Scholarly

Activity by Discipline............. . .118

45 Mean Hours/Week Spent on Research/Scholarly

Activity by Rank. . . . . . . . . . . . . . .119

46 Mean Hours/Week Spent on Research/Scholarly

Activity by Current Engagement . . . . . . .120

47 Mean Hours/Week Spent on Research/Scholarly

Activity by Recelpt of Internal Research

Support . . . . . . . . . . . . . 121

48 Percentage of Faculty Currently Engaged in

Scholarly Activities by Institutional Type . .122 


\section{List of Tables cont inued}

Table

Page

49 Percentage of Faculty Currently Engaged in Scholarly Activities by Gender . . . . . . .123

50 Percentage of Faculty Currently Engaged in

Scholarly Activities by Tenure Status . . . 124

51 Percentage of Faculty Currently Engaged in

Scholarly Activities by Discipline... . . .126

52 Percentage of Faculty Currently Engaged in

Scholarly Activities by Rank. . . . . . . .127

53 Percentage of Faculty Currently Engaged in

Scholarly Activities by Hours per Week Spent

on Research/Scholarly Activities . . . . . . .128

54 Percentage of Faculty Currently Engaged in

Scholarly Activities by Recelpt of Internal

Research Support............. . 130

55 Percentage of Faculty Who Recelved Internal

Research Support by Institutional Type . . . .131

56 Percentage of Faculty Who Received Internal

Research Support by Gender . . . . . . . .132

57 Percentage of Faculty Who Recelved Internal

Research Support by Tenure Status . . . . 133

58 Percentage of Faculty by Discipline who Received

Internal Research Support . . . . . . . . 134

59 Percentage of Faculty Who Received Internal

Research Support by Rank. . . . . . . . 135

60 Percentage of Faculty Who Recelved Internal

Research Support by Current Engagement . . . .136

61 Percentage of Faculty Who Received Internal

Research Support by Hours per Week Spent on

Research/Scholarly Activities . . . . . 13? 


\section{List of Tables continued}

Table

62 Multiple Regression Summary Table: Articles in Academic or Professional Journals . . . . 140

63 Multiple Regression Summary Table: Articles in Edited Collections or Volumes . . . . . . 141

64. Multiple Regression Summary Table: Books or Monographs Published or Edited Alone or in Collaboration . . . . . . . . . . 142

65 Multiple Regression Summary Table: Professional Writings Published or Accepted for Publication in the Past Two Years... . . . . . . 143

66 Multiple Regression Summary Table: Recelpt of External Research Support . . . . . . . 144 


\section{Chapter 1}

\section{Introduction to the Study}

Why some faculty maintain a high level of research productivity year after year and others do not remains an enigma in higher education Cole \& Zuckerman, 1984; Long, 1978). Variation in faculty research performance tends to be very high and the average rate of individual faculty publication very low (Allison, 1980; Fox, 1983; Robbins, Corcoran, Hepler, \& Magner, 1986). While one commonly finds four explanations in the literature for this variance in faculty research productivity--psychological-individual factors, cumulative advantage, reinforcement, and disciplinary norms--no single study analyzes all four explanations (Creswell, 1985a, p. 241; Wood, 1990, p. 83).

Esychological-individual factors include Intelligence scores (Cole, J. \& Cole, S. 1973; Cax, 1980;, motivation to engage in research/scholarly activities Cole, J. \& Cole, S. 1973; Merton, 1973; Pelz \& Andrews, 1966), personality characteristics (Fox, 1983; Roe, 1953), stress (Horowitz, Blackburn, \& Edington, 1984), age (Reskin, 1980), and gender (Astin, 
Eaculty research productivity 2

1984; Cole, J. 1979; Cole \& Zuckerman, 1984).

Cumulative advantage is based on Merton's (1973)

"Matthew effect" in science ( $1 . e$. , when scientists

receive recognition or resources, they gain additional

advantages). Cumulative advantage factors include

prestlge of the doctoral program, mentoring, prestige

of the employing institution, academic resources

(including internal research support), and assignment

that allows time for research (Allison \& Stewart, 1974;

Cole, J. \& Cole, S. 1973; Merton, 1973). Based on the

Skinnerian principle that an activity which is rewarded is more likely to be continued than an activity whlch is not rewarded, reinforcement refers to recognition by colleagues (Gaston, 1978; Reskin, 1977), academic rank (Reskin, 1977), tenure (Reskin, 1977), early productivity (Blackburn, Behymer \& Hall, 1978; Cole, J. \& Cole, S. 1973; Llghtfield, 1971, p. 133; Manis, 1951), and preference for research (Blackburn, Behymer \& Hall, 1978; Cresswel1, Barnes \& Wendel, 1982). The norms of a discipline also explain part of the varlance in the research performance of faculty (Astin, 1978; Blackburn, Behymer \& Hall, 1978; Cole, S. 1979; Storer, 1973, p. xvil; Wanner, Lewis \& Gregorio, 1981). 
Faculty research productivity 3

Some studies of faculty research performance (Allison \& Stewart, 1974; Gaston, 1978) have discussed as many as three of the four explanations for the varlance in faculty research productivity-psychological-individual, cumulative advantage, and reinforcement. A study of leading researchers in nursing conducted by Megel, Langston, and Creswell in 1988 examined these three explanations and provided a model for studying factors influencing scientific research productivity (p. 47).

The importance of high research performance is widely accepted and understood by those working on college and university campuses (Creswell, 1985, p. 1). However, speciflc factors identifled as correlates of high research productivity are "fraught with measurement problems, unclear causality, and unspecified predictlve power" (Creswell, I1i〉.

In spite of more than ninety studles of faculty research productivity conducted since 1940 (Fox, 1983), measures of research performance remain unclear and problematic (Clemente, 1972; Creswel1, 1985, 1ii). Any attempt to measure faculty research performance 
Faculty research productivity 4

disturbs some who consider 1 t to be unmeasureable (Yuker, 1978).

For this study, self-report data from the 1989 Carnegie Survey of the professoriate were utilized to report faculty research productivity. The Carnegie Foundation for the Advancement of Teaching has conducted a serles of four surveys in 1969, 1975, 1984, and 1989 to "clarify the status of the professorlate and. . provide a portrait of American higher education" (Carnegie, 1989).

Many studies of faculty research productivity are limited by their failure to account adequately for factors such as institutional affiliation, academic rank, discipline, tenure status, and gender (Creswell. 1985, vil). Fallure to control for such factors poses limits to college and university administrators for translating research findings into viable approaches to faculty evaluation. Moreover, data reported from national studies of faculty research productivity that do account for such factors are typically aggregated to such an extent that subsequent use of the results by college and university administrators is deemed impractical (Gil1, 1991). In this study, the researcher 
Faculty research productivity 5

disaggregated the data by institutional affiliation, rank, discipline, tenure status, and gender in order to facilitate use of the data by faculty and administrators.

\section{Purpose of the Study}

The purpose of this study was to examine the relatlonship between and among psychological-individual factors, cumulative advantage, reinforcement, and disciplinary norms-factors that account for variance in research performance--and individual faculty research productivity as measured by self-report data on the 1989 Carnegie Survey of faculty. Studying faculty research productivity in this manner incorporated the four explanations for variance in faculty research performance in a single study. In order to Investigate this problem, the individual research performance of full-time faculty was studied by institutional affiliation, academic rank, discipline, tenure status, gender, the hours spent per week on research and/or comparable scholarly activities, current engagement in scholarly work, and the receipt of internal research support in the past 
Faculty research productivity 6

twelve months. Self-report data relatlve to publlication counts, which are commonly used as measures of individual research productivity (Creswell, 1985, p. 7), and external research support received by faculty within the last twelve months (Megel et al., 1988, p. 47) were used as measures of research performance.

It is antlclpated that the results of this study will benefit scholars of higher education by increasing the understanding of individual faculty research productivity. Because of the high degree of variance in faculty research performance, it is anticipated that the results of this study wlll be an important information source for presidents, deans, chairs, and personnel committees who revlew faculty credentials from different departments and disclplines. 
Eaculty research productivity 7

\section{Rationale for the Study}

From the early 1980s, an aggressive movement to "upgrade the importance of scholarly productivity as a criterion for academic personnel decisions" has been observed in diverse colleges and universities throughout the United States (Bowen \& Schuster, 1985, p. 14). The "research surge" has not been limited to "universities" but has been prevalent at other institutions where research previously recelved lower priority status (Bowen \& Schuster, 1986, p. 147; Seldin, 1984). Findings from a study of fifty-nine chairs of promotion and tenure committees in ninety-three universities with accredited master of social work programs indicated that research/scholarly productivity was the central criterion for making promotion and tenure declsions (Gibbs \& Locke, 1989). Fifty-four percent of all faculty surveyed by the Carnegie Foundation in 1989 indicated that it was difficult for one to achleve tenure if he or she did not publish, and fifty-seven percent reported that the number of publications was important (Carnegie, 1989 , pp. 48-49). However, sixty-eight percent of the faculty 
Faculty research productivity 8

surveyed agreed that better ways, besides publications, were needed to evaluate the scholarly performance of faculty (Carnegie, p. 52).

Research productivity of science and social science faculty, the disciplinary groups that have been studied most (Creswell, 1985, pp. 22-23), has traditionally been measured by publication counts (Caplow \& McGee, 1958; Folger, Astin, \& Bayer, 1970), citation counts (Bayer \& Folger, 1966; Kroc, 1983; Lindsey, 1978; Smith \& Flelder, 1971), and or peer or colleague ratings CCentra, 1977; Cole, S. 1979; Folger, Astin, \& Bayer, 1970; Pelz \& Andrews, 1966; Seldin, 1984). While these three measures of faculty research performance are intercorrelated (Creswell, p. 7), few writers consider alternative measures of scholarly productivity (Finkelstein, 1984). Creswell suggests empirical studies of faculty research productivity should include such measures as "grants obtained. patents, and creative projects" (p. 7).

Self-report data from the 1989 Carnegle Faculty Survey were utilized in this study to examine faculty research productivity. As Creswell has recommended (1985, p. 5), criterla other than publications, 
Faculty research productivity 9

citations, and ratings were used to measure faculty research performance. Current engagement in any scholarly work that one expects to lead to a publication, an exhibit, or a musical recital was used as a correlate of research productivity measures. In this study, the criteria for measuring faculty research productivity are as follows: the number of articles published in academic or professional journals, the number of articles published in edited collections or volumes, the number of books or monographs published or edited alone or in collaboration, the number of professional writings published or accepted for publication in the past two years, and the receipt of external research support within the last twelve months.

Substantlally modifying the model developed by Megel, Langston, and Creswell (1988) to include all four explanations for varlations in research performance (Creswell, 1985; Finkelstein, 1985), the researcher studied research productivity of full-time faculty. For psychological-individual explanations, faculty research performance was examined by gender and current engagement in scholarly work. To include 
Eaculty research productivity 10

cumblative advantage factors, faculty research productivity was studled by institutional type, hours spent per week on research and or comparable scholarly activities, and internal research support recelved during the last twelve months. In order to examine reinforcement, faculty research performance was examined by academic rank and tenure status. Individual research productivity of faculty was also studied by discipline.

Acknowledging that faculty performance includes teaching and service as well as research (Kirschling, 1978; Yuker, 1978), the researcher chose to limit the proposed study to factors related to "research" productivity. Hoffman (1984) concluded that effective faculty performance in teaching, research, or service did not predict success in either of the other performance areas.

Further, this study focused only on individual faculty research. Institutional, departmental, or colleglal analyses of research productlvity are available in studies done by Kroc (1983) and Wallhaus (1975). 
Faculty research productivity 11

\section{Research Questions}

The study ut 111 zed quantitative methods through the employment of a self-reported questionnaire to study faculty research productivity.

The following research question prompted this study and was of primary importance in this research.

How does the level of faculty research productivity vary by institutional type? by academic rank? by discipline? by tenure status? by gender? by the number of hours spent per week on research and or scholarly activities? by current engagement in scholarly work? by internal research support?

In order to answer this primary research question, subsidiary questlons were addressed.

1. How many hours per week do faculty spend on research and or comparable scholarly activities?

2. What percentage of faculty is currently engaged in scholarly work that is expected to lead to a publication, an exhibit, or a musical recital?

3. What percentage of faculty has recelved internal research support during the past twelve months?

4. What is the level of faculty productivity as determined by (a) the number of articles published in academic or professional journals? (b) the number of articles published in edited collections or volumes? ( $c$ ) the number of books or monographs published or edited alone, or in collaboration? (d) the number of professional writings published or 
Faculty research productivity 12

accepted for publication in the past two years? (e) the receipt of external research support within the last twelve months?

5. What percentage of variance in faculty research productivity can be explained by (a) institutional affiliation? (b) rank? (c) discipline? (d) tenure status? (e) gender? ( $f$ ) hours spent per week on research and or scholarly activities? ( $g$ ) current engagement in scholarly work? ( $h$ ) receipt of internal research support? 


\section{Chapter 2}

\section{Review of Related Literature}

Research is one of the primary roles of faculty in American colleges and universities (Finkelstein, 1984). Furthermore, faculty are often recruited, hired, valued, and rewarded based on their research productivity. The following literature review establishes the framework for this study of faculty research productivity.

In order to understand the issues surrounding this study, it is necessary to synthesize the literature and research conducted previously in several topic areas. A brief summary of the history of the research role of faculty is provided to illustrate the emerging importance of this role for faculty. The philosophical context of research is examined to provide a contextual understanding of the faculty research role. Specific factors identified in the literature as correlates of faculty research productivity are presented in terms of previous studies. In particular, institutional affiliation, academic rank, discipline, tenure status, gender, and resources will be discussed as they relate to faculty research performance. Finally, a model 
Faculty research productivity 14

developed by Megel, Langston, and Creswell (1988) for studying factors influencing sclentific research productivity is presented.

Historical Development of the Research Role for Faculty

Enthusiasm for research came from Germany to the United States during the post-Civil war period and was manifested in American universities by the 1870 s (Veysey, 1965). Johns Hopkins University, opened as a graduate school for men in 1876, embodled the Germanic alm of research. However, Daniel Colt Gilman, the first president of Hopkins, was never entirely comfortable with the term "research" and "had no desire to replace the conventional American college with a Germanic university" (Veysey, p. 159). Gilman sald that the American university should never become

merely a place for the advancement of knowledge or for the acquisition of learning; it will always be a place for the development of character. A society made up of specialists, of men who have cultivated to the extreme a single power, without 
Faculty research productivity 15

simultaneously developing the various faculties of the mind, would be a miserable society of impractical pessimists... (Gi)man, 1886, p. 210).

Profound commitment to research during this time was usually limited to a particular segment of the faculty and graduate students. As individual departments of learning evolved in the 1880 s and 1890 s, they were often split internally between identification with academic ideologies and devotion to research (Veysey, 1965, pp. 59-60). While the distinction between pure and applled research was never exact, "pure" or non-utilltarlan research was deflned as "learning for its own sake" (Veysey, p. 122). Illustrative of this dichotomy in orientation of American institutions of higher learning during the latter part of the nineteenth century was the establishment of a School of Pure Science at Columbia, in 1890 , with a separate Faculty of Applied Science (Veysey, p. 122).

Twenty-four American graduate schools evolved in the 1880 s and $90 \mathrm{~s}$, with one-half of the students 
Faculty research productivity 16

enrolled in natural sciences and social sciences (history and psychology) and one-third engaged in the study of languages (Veysey, 1955, p. 173). Only one-tenth of the graduate students majored in philosophy or the fine arts, disciplines that had "resisted a scientific perspective" (Veysey, p. 173).

The impetus for research had become a primary concern of higher education by 1890. Colleges and universities encouraged their faculty to take leave to pursue advanced degrees. By 1893, graduate work was necessary in order to gain a permanent appointment at prominent colleges and universitles, and, by 1900 , the Ph.D. was usually mandatory (Veysey, 1965, p. 176). The Association of American Universities (AAU), founded in 1890, viewed research as "the intrinsic function of "the' university in the United States" (Veysey, $p$. 175). In 1901, Yale announced that promotion of faculty would be based on "productlve work" that would give the faculty a "national reputation" (Veysey, p. 177). Requiring a minimum amount of teaching, the first "research chair" was established at Cornell in 1909 (Veysey, p. 176). While controversy was to be ongoing, by 1910 research had nearly gained the prominence in 
academia that it was to maintain thereafter, counted among the other demands placed on institutions of higher learning (Veysey, pp. 177-78).

The growth of research influenced American higher education in two significant ways: by fostering increased specialization of knowledge and by accepting the "liberation of intellect for its own sake" (Veysey, 1965, p. 142). With the growing emphasis on research was a concomitant tendency to devalue the undergraduate college and the teaching role (Veysey, pp. 143-44).

Scholars began to study the research role of faculty in the 1940 s and 50 s. One of the first studies of faculty research productivity was Logan WIlson's (1942) The Academic Man. In this study, Wilson concluded that faculty who confined their activities to classroom teaching were promoted more rapidly than those persons who publ ished research. Fifteen years later, Lazarsfeld and Thielens (1958) studied highly productive social scientists and found that, as a group, they tended to hold an offlce in one or more professional organizations, move from one institution to another, and come from a high socloeconomic level. 
Faculty research productivity 18

Interest in research productivity increased from a practical perspective during the post-sputnik era, as pol icymakers became concerned about maximizing research performance (Kaplan, 1964). Having recelved funding from the National Institutes of Health and the Carnegie Corporation, Pelz and associates at the University of Michigan conducted a six-year study to determine what factors create a stimulating environment for research and development (Pelz \& Andrews, $1966, p, 1$ ). This line of research as well as studies on the social structure of institutions and the Individual characterlstics of its participants (Merton \& Gaston, 1977; Storer, 1973) has provided important baseline information for the study of research performance and has "added substance and depth to a field of study known today as the sociology of science" (Creswell, 1985, p. 3). 
Faculty research productivity 19

Philosophical Context of the Faculty Research Role

While the modern role of American faculty includes research, teaching, institutional service, and community service, faculty view themselves predominantly as teachers, spending most of their work hours teaching or in teaching-related activities (Bowen \& Schuster, 1986; Fulton \& Trow, 1974). Baldwin and Blackburn (1985) reported that a uniform high ranking of the importance of teaching remained stable over the career span of faculty. In splte of the fact that the majority of faculty has never published or has published very 11 ttle, research appears to be valued as a very important activity for faculty in postsecondary education (Ladd, 1979). As Creswell (1985, p. Xv) noted,

Presidents and trustees value productivity for the visiblility and reputation it indirectly earns for the institution. Administrators and deans admire productivity for the creative, stimulating forces it brings into the collegial atmosphere. The 
Faculty research productivity 20

academic community smiles upon scholarly work because it advances knowledge.

Research productivity is being stressed at institutions other than research, doctoral-granting, and major universities (Seldin, 1984). Having visited thirty-elght diverse Amerlcan colleges and universities during the early 1980s, Howard Bowen and Jack Schuster observed an aggressive movement to "upgrade the importance of scholarly productivity as a criterion for academic personnel decisions" (Bowen \& Schuster, 1985, p. 14). Bowen and Schuster noted that the "research surge" was not limited to "unlversities" but was prevalent at other institutions where research had previously recelved lower priority status (Bowen \& Schuster, 1986, p. 147).

Faculty research productivity becomes an avenue to establish an institution's reputation (Bowen \& Schuster, 1985, p. 150; Meisinger, Purves, \& Schmidtlein, 1975) and a quantltatlve element in the promotion and tenure process (Ladd, 1979). In addition, faculty research contributes to the public domain of knowledge (Carnegie, 1980; 2 iman, 1968). Penicillin, 
the computer, and the pollo vacclne were developed through research conducted in unlversitles (Bowen \& Schuster, 1986, p, 17).

Research performance, like teaching, is more intrinsically than extrinsically motivated (Einkelstein, 1985; Hunter \& Kuh, 1984; Kearney, 1987; Mckeachle, 1969; 0'Connel1, 1983). Finkelstein (1980) found that faculty research productivity patterns apparently do not reflect the "performance demands. . - in institutional incentive structures" ( $p .23\rangle$ but rather faculty's "individual predilections" (p. 24). In a study of highly successful researchers in mass communications research departments (Schweltzer 1989), ninety-seven percent of the respondents cited personal motivation as their strongest single productivity factor.

Research performance, unlike teaching, is supported by institutions in terms of providing tangible rewards, stimulating colleagues, and providing opportunities for growth (Finkelstein, 1985, p. 5; Schuster \& Wheeler, 1990, pp. 94-95; Tuckman, 1985). Research is also supported "by the norms and 
Faculty research productivity 22

expectations of the academic disciplines and professional fields" (Finkelstein, p. 5).

In American colleges and universities, research productivity is playing an increasingly important role in academic decision-making. (Creswell, 1985, p, xv).

\section{Correlates of Faculty Research Productivity}

The variation in faculty research productivity can be explained, in part, by institutional affillation, academic rank/age, gender, discipline, tenure status, and resources.

Institutional Affiliation

A recent study of the effects of organizational context characteristics and individual characteristics on the research performance of chemistry faculty indicated that organizational context advantages, such as the research orlentedness of the afflliated institution, were related to high faculty research productivity ( $\mathrm{KIm}, 1990)$. No Individual characteristics in this study were found to be signiflcantly related to faculty publication productivity. 
Faculty research productivity 23

Prestigious institutions attract talented graduate students to faculty positions (Crane, 1965), and, in turn, the employing institution molds individual research performance (Creswell in Flnkelstein, 1985, p. 256). The correlation between the prestige of the employing institution and individual research productivity increases over time (Long \& McGinnis, 1981 ). Long and McGinnis (1981) found that faculty research productivity was largely determined by the context of a new employing institution within six years of obtaining a position.

Why prestigious institutions enhance faculty research productivity is unclear, however (Fox, 1983). Long (1978) proposed that prestiglous institutions have the resolve and ability to select those individuals who will become high research producers, while Crane (1965) reasoned that prestiglous institutions are able to recrult highly talented faculty and offer faculty high visibility and contacts. Creswell (in Finkelstein, 1985, p. 257) made the following observation:

Papers submitted by faculty in prestigious departments may appear superior and be more 
readily accepted for publication. Prestigious departments and institutions tend to be larger and to possess resources and colleagues that facilitate research.

\section{Academic Rank/Age}

Academic rank is highly correlated to faculty research productivity (Creswell, 1985, p. 40). Overall, faculty in the higher academic ranks have larger numbers of publications to their credit than do faculty in the lower academic ranks (Blackburn, Behymer \& Haill, 1978; Fulton \& Trow, 1974). While this relationship is to be expected, the causal direction between academic rank and faculty research performance remains unclear. Finkelstein (1984, p. 101) believes selection factors account for the association between rank and publication rate. He thinks that

- . promotion to a higher rank may be a function of an already demonstrated publication rate, which persists in the new status (Finkelstein, 1984, p. 101). 
In a study of performance levels and promotion experiences of 371 unlversity faculty members under three different market conditions, Perrucci, O'Flaherty, and Marshall (1983) found that faculty promoted during a buyer's market remain in rank longer before being promoted and exhibit a higher level of productivity than faculty promoted during other market conditions. In this study, the impact of "tight" market conditions on faculty research performance was found to be greater for faculty below the rank of full professor (Perucci et a! .).

Complex measurement and other methodological problems make the relationship between faculty research productivity and age difficult to determine. Some studies use chronological age (Cole, S. 1979; Pelz \& Andrews, 1966), while other studies use years of professional experience (Creswell, Patterson \& Barnes, 1984), number of years since the doctorate was received (A111son \& Stewart, 1974; Bayer \& Dutton, 1977), or a combination of academic rank and career age (Baldwin \& Bl ackburn, 1981).

Pelz and Andrews (1966) have identified a saddle-shaped or dual curve of scholarly productivity 
Faculty research productivity 26

with respect to age, L.e., an early rise, a subsequent fall, and then another rise during the fifties. This study was corroborated by Blackburn, Behymer, and Hall (1978), who reported a decrease in faculty research productivity at the associate professor stage and a subsequent increase at the full professor stage.

Research conducted by Bayer and Dutton (1977)

revealed a direct decline of faculty research productivity according to career stage, with article publication peaking at approximately five to ten years of career age. While this study reported only a slight decrease in research productivity among faculty with twenty-five years of career age, it found a notable increase in the number of faculty who were not producing any scholarly work.

In a national study of faculty, Fulton and Trow found that faculty, with increasing age, focused their time and energies on teaching at the expense of research $(1974$, p. 54). This study reported that faculty described themselves as "exclusive teachers" with twice the frequency and as "strong researchers" with half the frequency between the ages of thirty-one to thirty-five and fifty-six to sixty. 
Faculty research productivity 27

Using a twenty-two field sample, Tuckman (1985) studied four faculty activities--teaching, public service, publishing books, and publishing articles. He concluded that publishing articles had the greatest impact on a faculty member's chances for promotion ( $p$. 127), with the contribution being stronger at the rank of associate professor than at the full professor level.

Literature relevant to faculty research productivity and age supports conflicting assumptions: while faculty research performance lmproves with experience, aging impairs research productivity (Creswell in Finkelstein, 1985, p. 242). Reskin (1980) postulated that the positive and negative effects of aging could negate one another or operate independently at different career stages.

Several factors can affect the relationship between faculty research productivity and age. These include motivation, risk-taking, stamina, socialization to research norms, the institutional reward system, competing demands on time, extraprofessional roles, and the effect of scientific specialties (Reskin, 1980). 
Faculty research productivity 28

Age has been found to be an insignificant correlate of faculty research productivity when research performance was regressed against gender, academic rank, and the research standing of the employing institution (Over, 1982). Because age correlates highly with academic rank, Blackburn, Behymer, and Hall (1978) eliminated age entirely in their final statistical analysis. Based on the correlation between research performance and academic rank, the researcher has chosen to report faculty research productivity in this study by academic rank.

Discipline

The norms of a discipline and the knowledge in the field of study explain, in part, variations in faculty research productivity (Blackburn, Behymer, \& Hall, 1978; Blau, 1973; Finkelstein, 1985; Wanner, Lewis, \& Gregorio, 1981; Wilson, 1942; Wood, 1990, p. 85).

Natural scientists, as a group, emerge as the most productive; faculty in the humanities, education, and the fine arts, as the least productive; and social scientists fall 
Faculty research productivity 29

somewhere in between. (Finkelstein, $1984, p$. $100>$.

This rank order when comparing productivity variables for three disciplinary categories--natural sciences, social sciences, and the humanlties--was found in earlier studies conducted by Wanner, Lewis, and Gregorio (1981) and Biglan (1973).

The norms of a discipline have a twofold effect on faculty research productivity. First, disciplines differ in the stage of paradigmatic development, in the understanding of the accepted theory, in the preferred methodologies, and in the understanding of important areas to study (Kuhn, 1970). Social sclences, for example, are immature fields considered to be in a pre-paradigmatic stage, while the physical sciences are mature fields in a paradigmatlc stage. Lodahl and Gordon suggest the paradigm "provides structure by suggesting which problems require investigation next, what methods are approprlate to thelr study, and even which findings are indeed 'proven'" (1972, p. 58). Second, fields of study differ in their research 
Faculty research productivity 30

activities (Zuckerman \& Merton, 1973), called the social activities of disciplines by Gaston (1978). The paradigmatic stage of a discipline affects scholarly research (Lodahl \& Gordon, 1972) in terms of acceptance rates in journals (Gaston, 1978) and the form of communication (Biglan, 1973). In disciplines in which the knowledge is codifled to a high degree (e.g., physics), the acceptance rates are high. Further, in disciplines in a paradigmatic stage, abbreviated forms of scholarly publications--journal articles--are accepted. In pre-paradigmatic disciplines, such as education, lengthened communication forms--books and monographs--are required (Biglan).

Disciplines also vary in terms of the research activities. These differences in research activities include the amount of concern scientists express relative to the priorlty to be placed on their current research, the average number of papers produced annually, the age of the literature included in scholarly papers, the validity of publlshed answers to research questions, the extent to which mathematics is ut llized in research, the coauthorship patterns, the reliance on research assistants, and the division of 
Faculty research productivity 31

labor. on scholarly works that require various collaborators (Gaston, 1978).

\section{Tenure Status}

Tenure is an integral issue in faculty research productivity (Chait \& Ford, 1985; Wood, 1990). Alstyne (1985, p. 167) made the following observation:

The function of tenure is not only to encourage the development of specialized learning and professional expertise by providing a reasonable assurance against the dispiriting risk of summary termination; it is to maximize the freedom of the professional scholar and teacher to benefit soclety through the innovation and dissemination of perspectives and discoveries alded by his investigations, without fear that he must accommodate his honest perspectives to the conventional wisdom.

While tenure is an issue in faculty research performance (Chait \& Ford, 1985), the granting of tenure may not be an incentive to increase the level of 
Faculty research productivity 32

research performance (Creswell, 1985, p. 40). Holley (1977) found a posttenure decrease in the level of faculty research performance across institutional types. Conducting a study of faculty research productivity in four departments-- physics, chemistry, sociology, and political science--Neumann (1979) reported insignificant differences in publication rates between tenured and non-tenured faculty. Because of this defacto relationship between granting tenure and the level of faculty research performance, Blackburn, Behymer, and Hall (1978) concluded that few mistakes will be made by granting tenure to faculty who are productive.

\section{Gender}

While there is compelling evldence that males publish more than females (Astin, 1984, 1969; Babchuk \& Bates, 1962; Cole, J. 1979; Cole \& Zuckerman, 1984; Hargens, McCann, \& Reskin, 1978) and are consequently more frequently cited (Persell, 1983), the literature is less conclusive relative to the reasons for the differences in output (Cole \& Zuckerman). 
Several possible explanations for the variation in faculty research productivity by gender have been suggested. One such explanation proposed that women do not have access to the "old boy" network and are not privy to the scientific information being exchanged (Creswell in Finkelstein, 1985, p. 242). Another explanation that has been offered is that women's work is not taken serlously by the academic community; that 1s, their work is often dismlssed by those in powerful positions (Creswell in Finkelstein, 1985, p. 242). Cole and Zuckerman (1984) found that female scientists seemed to be discouraged more readlly than male scientists and were less readily encouraged by having their work cited to varying degrees. Another possible explanation for females publishing less than males has to do with traditional family responsibilities that would prevent women from spending as much time on research activity as men (Creswell in Finkelstein, 1985, p. 242). However, in a study of faculty research performance conducted by Ferber and Loeb (1973), married females with or without children were found to be no less productive than single women. Stephen Cole (1979) found that the stabllity and routine often 
Faculty research productivity 34

associated with marriage and family are positively related to high faculty research productivity.

While gender helps to explain variations in the quantity of faculty research publications (Rosenfeld, 1987), it is, comparatively, an insignificant correlate of faculty research performance because of its high correlation with other variables (Bernard, 1964; Blackburn, Behymer, \& Hall, 1978; Cameron \& Blackburn, 1981; Cole \& Zuckerman, 1984). 
Faculty research productivity 35

\section{Resources}

In order to be highly productive researchers, faculty need resources that support their research agendas (Cole, S. 1979; Creswel), 1985, p. 50; Fox, 1983, p. 297; Ingalls, 1982; Wood, 1990, p. 87). One of these resources is time. Faculty and administrators often overlook the need to assign research time to the faculty load (Creswe 11, p. 50). While the amount of time faculty spend on research has been found to be an important predictor of high research productivity (Allison \& Stewart, 1974; Harrington, 1985), the amount of time assigned as part of the workload for faculty for research "need not be excessive" (Creswel1, p. 50). Spending too much or too little time on research activities can hamper research productivity (Pelz \& Andrews, 1966). Spending less thar ten percent or more than eighty percent of one's work time on research activities has been assoclated with low research performance (Knorr, Mittermelr, Alchholzer \& Waller, 1979). Research productivity peaked among scientists when about one-third of their work time was spent on research (Knorr et a.1.). 
Faculty research productivity 36

Research grants are another source of research support for faculty. Use of monies for research varles by departments (Wood, 1990). For example, equipment is more essential in the sciences than in the social sciences, where research funds for travel and personnel to transcribe interviews are considered very important. In music and drama, funds are needed to offset the costs associated with performances and productions (Wood, p. 88). Liebert (1976) found that grant receipt depends primarily on faculty research productivity, secondarily on the inequalities in favor shown to specific flelds, and very little on particular situational and personal status factors.

Faculty need internal research support to have productive research careers (Creswell, 1985, p. 50; Ingalls, 1982; Wood, 1990). Among the resources that faculty need are sufficient computer time, research assistants, secretarial support, internally funded research grants, sabbatical leave grants, equipment, and faculty travel funds. 
Faculty research productivity 37

Scholarly Productivity Model

A study of leading nurse-faculty researchers conducted by Mege1, Langston, and Creswell in 1988 examined psychological-individual, cumulative advantage, and reinforcement explanations for the variance in faculty research performance, and provided a model for studying factors Influencing scientiflc research productivity $(p, 47)$. In the study conducted by Megel et al., tenure, discipline, and doctoral preparation were control variables. Measures of scholarly productivity included research articles, Journal artlcles other than research, books/ monographs, book chapters, papers presented at regional/national meetings, posters presented, and external research grants. Five time periods were used to measure research productivity: before doctorate, after doctorate before tenure, tenure through present, last three years, and career. 
Faculty research productivity 38

MEGEL/LANGSTON/CRESWELL MODEL

Correlates of

Productivity

PSYCHOLOGICAL INDIVIDUAL

I FACTORS

I MotIvatIon

1 Personal preferences

Age: Chronological

I Years of experience

I Rank

Intervening (Control)
Variables

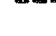

\author{
Measures of Scholarly \\ Productivity \\ Regearch articles \\ Journal articles other \\ than research
}

Books/monogr aphs

Book chapters

Papers presented

(regional/national meetings)

External research grants
I REINFORCEMENT FACTORS

I Coll eagues

I Early productivity
Posters presented

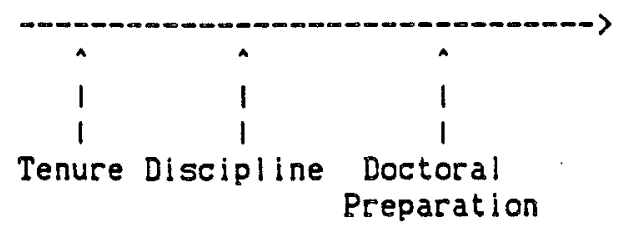


Faculty research productivity 39

The purpose of the study conducted by Megel et al. (1988) was to Identify the factors that explain the differences among nursing researchers in terms of faculty research productivity. From this study, the profile of a productive nurse-faculty researcher emerges as an individual who has

published slightly less than one research article per year for the last three years, has a record of increasing productivity during his or her career and published before obtaining the doctorate, is motivated to conduct research by peers outside the institution and fellow research team members Inside the institution, likes conducting and writing research and writing research grant proposals, tends to have coauthored research papers with mentors in graduate school, spends less time teaching than the combined time given to conducting and writing research, and spends a substantial amount of time on administrative duties (Megel et al., 1988, p. 53). 


\section{Chapter 3}

\section{Design and Methods}

This research was a descriptive study that used quantitative methods to describe the relationship between levels of faculty research productivity and instltutional afflliation, academic rank, discipline, tenure status, gender, the hours per week that faculty spend on research and related scholarly activitles, the current engagement of faculty in scholarly work, and the receipt of internal research support within the last twelve months. Levels of faculty research productivity were based on the number of articles published in academic or professional journals, the number of articles published in edited collections or volumes, the number of books or monographs published or edited alone or in collaboration, the number of professional writings published or accepted for publication in the past two years, and the recelpt of external research support within the last twelve months. These measures of faculty research productivity are reported by the following factors. 
Faculty research productivity 41

1. Institutional type: Research I, Research II, Doctorate I, Doctorate II, Comprehensive I, Comprehensive II, Liberal Arts I, Liberal Arts I I

2. Academic rank: Professor, Associate Professor, Assistant Professor, Instructor

3. Discipline: Biological Sciences, Business, Education, Englneerling, Fine Arts, Health Sciences, Humanities, Physical Sciences, Social Sciences, Other

4. Tenure status: Tenured, Non-tenured

5. Gender

6. Number of hours per week spent on research and comparable scholarly activities

7. Current engagement of faculty in scholarly work

8. Internal research support received by faculty within the last twelve months

The researcher used multiple regression to determine the percentage of varlance attributed to the eight faculty research productivity correlates (predictors) for each of the five measures of faculty research performance.

Self-report data for the study were generated by the 1989 survey of the professorlate conducted by the Carnegie Foundation for the Advancement of Teaching. 
Faculty research productivity 42

Allison and Stewart (1974) estimated the reliability of self-reported information relative to faculty research productivity by comparing responses from chemists to publication counts from Chemlcal Abstracts and found the correlation was $r=.94$. For this study, the unit of analysis was individual responses of faculty members who returned the 1989 Carnegie Survey. The researcher answered the research questions through subsequent data analysis.

\section{Research Questions}

Primary Research Question:

How does the level of faculty research productivity vary by institutional type? by academic rank? by discipline? by tenure status? by gender? by the number of hours spent per week on research and or scholarly activities? by current engagement in scholarly work? by internal research support?

Subsidiary Research Questions:

1. How many hours per week do faculty spend on research and or comparable scholarly activities?

2. What percentage of faculty is currently engaged in scholarly work that is expected to lead to a publication, an exhibit, or a musical recital?

3. What percentage of faculty has received internal research support during the past twelve months? 
4. What is the level of faculty productivity as determined by (a) the number of articles published in academic or professional journals? (b) the number of articles published in edited collections or volumes? (c) the number of books or monographs published or edited alone, or in collaboration? (d) the number of professional writings published or accepted for publication in the past two years? (e) the receipt of external research support during the past twelve months?

5. What percentage of variance in faculty research productivity can be explained by (a) institutional affiliation? (b) rank? (c) discipline? (d) tenure status? (e) gender? ( $f$ ) hours per week spent in research and or scholarly activities? ( $g$ ) current engagement in scholarly work? ( $h$ ) recelpt of internal research support?

\section{Research Model}

Substantially modifying the research model developed by Megel, Langston, and Creswell (1988, p. 47) to include all four explanations for the variance in faculty research productivity found in the literature and the correlates of faculty research performance germane to this study, the researcher utilized the following research model to examine faculty research productivity. 


\section{Faculty research productlvity 44}

RESEARCH MODEL

Correlates of

Productivity

- n- - - - - -

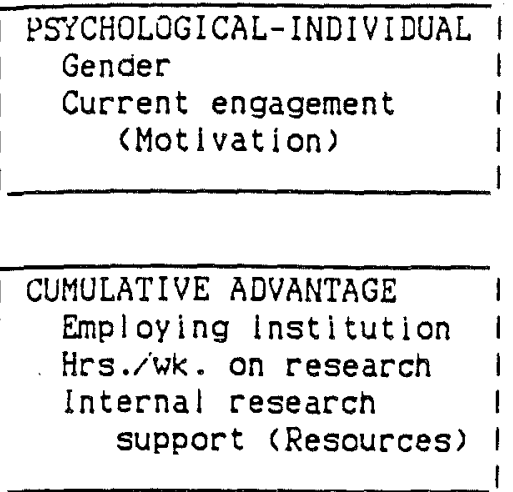

\section{REINEORCEMENT}

Rank

Tenure status
Intervening (Control)

Variable

- - - - - - - - - - - - - - -

\author{
Measures of Research \\ Productivity
}

Articles in academic or professional journals

Articles in edited

collections or volumes

Books or monographs published or edited

alone or in collaboration

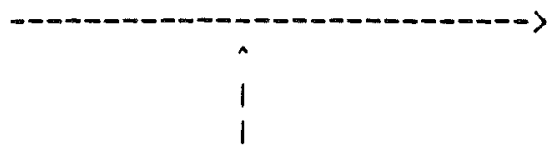

Full-time appointment
Professional writings published or accepted for publication in the past two years

External research support
DISCIPEINARŸ NORMS issipline 
Eaculty research productivity 45

The Research Model substantially differs from the Megel-Langston-Cresweli Model (MLC Model). While the MLC Model used tenure and discipline as control variables, the Research Model used these variables as correlates of faculty research productivity. By using tenure and discipline as research correlates, the researcher was able to examine the relationship between these variables and specific measures of research performance. The MLC Model also used doctoral preparation as a control variable. The sole control variable for the Research Model was full-time employment in the afflliated institution for at least nine months of the academic year.

Correlates of faculty research productivity in the MLC Model address factors related to only three of the four explanations found in the literature for the variance in faculty research performance-psychological-individual, cumulative advantage, and reinforcement. By adding the fourth explanation for the variance in faculty research productivity--discipline-to the Research Model, the researcher was able to address all four explanations. For psychologicalindividual factors the MLC Model used motivation, personal preferences, chronological age, years of 
Faculty research productivity 46

experience, and rank. The Research Model used gender and current engagement for psychological-individual factors. Current engagement was used as a motivational factor. For cumulative advantage factors, the MLC Model used prestige of the doctoral institution, mentoring, academic resources and assignment, and emphasis of the department. The Research Model used the type of employing institution, number of hours per week spent on research or comparable scholarly activities, and receipt of internal research support for cumulative advantage factors. In the Research Model, the recelpt of internal research support was substituted for academic resources used in the MLC Model. For reinforcement factors, the MLC Model used colleagues and early productivity. The Research Model used rank and tenure status for reinforcement correlates. Rank and tenure are considered to be a part of the reward structure in postsecondary institutions. While the MLC Model did not include disciplinary norms as correlates of faculty research productivity, the Research Model used discipline to complete a model which utilizes all four of the explanations found in the literature for the variance in faculty research performance. 
Faculty research productivity 47

There are similarities and differences relative to the productivity measures used in the two research models. Publications dominate the measures of research performance for both models. The MLC Model and the Research Model include four types of publications as measures of faculty research productivity. The MLC Model used research articles, journal articles other than research, books/monographs, and book chapters as scholarly productivity measures. The measures of faculty research productivity in the Research Model are articles in academic or professional journals, articles in edited collections or volumes, books or monographs published or edited alone or in collaboration, and professional writings published or accepted for publication in the past two years. The MLC Model also used papers presented at regional/national meetings and posters presented as research productivity measures. Both models include the recelpt of external research support as a measure of faculty research productivity. 
Faculty research productivity 48

\section{Definition of Terms}

The following terms vital to this study were included throughout the narrative.

Career Age: The number of years one practices a profession.

Data: "Numbers that are collected as a result of observations" (Runyon \& Haber, 1988, p. 7).

Descriptive Statistics: "Statistical procedures used in describing the properties of samples, or of populations where complete population data are available" (Ferguson \& Takane, 1989, p. 9).

Faculty Evaluation: The process for determining the value of faculty for the purpose of decision-making (Worthen \& Sanders, 1987, p. 22).

Mean: "The sum of a set of measurements divided by the number of measurements in the set" (Ferguson \& Takane, 1989 , p. 53).

Multiple Regression: A statistical technique used to predict one varlable from a knowledge of other variables (Ferguson \& Takane, 1989, p. 115).

Population: "A complete set of individuals, objects, or measurements having some common observable characteristic" (Runyon \& Haber, 1988, p. 7).

Random Sampling: A process by which "each element has an equal chance of selection that is independent of any other events in the selectlon process" (Babble, 1973, p. 83).

Research: All of the "activities of faculties that advance knowledge and the arts" (Bowen \& Schuster, $1986, \mathrm{p}, 16)$.

Research Performance: Engagement in research or scholarly activities. 
Research Productivity: Research and/or scholarly activity that is measurable. In this study the terms "research productivity" and "scholarly productivity" are used synonymously.

Sample: "A subset of a population selected in accordance with the research design" (Runyon \& Haber 1988, p. 8).

Scholarly Productivity: Research and/or scholarly activity that is measurable. In thls study the terms "scholarly productivity" and "research productivity" are used interchangeably.

Scholarly Work: Application or use of knowledge and skills acquired through and certified by doctoral research training (Braxton \& Toombs, 1982).

Stratified Sampling: Drawing elements from homogeneous subsets of a population (Babble, 1973, p. 94).

Variable: "A property whereby the members of a group or set differ one from another" (Ferguson \& Takane, 1989, p. 10). 
Faculty research productivity 50

\section{The Study Group}

A two-stage, stratified, random sample design was used to select college and university faculty for inclusion in the 1989 Carnegle survey. In the first stage, 306 four-year and two-year institutions were selected from the Carnegie Foundation data bank of U.S. colleges and universities. The institutions selected for the survey were equally divided among the nine Carnegie Classifications, with thirty-four colleges/universities per classification.

The number of institutions in each of the Carnegie Classifications based on 1986 statistics is as follows: 
Faculty research productivity 51

\section{Carnegie Classification \#Colleges/Universities}

$\begin{array}{lr}\text { Research Universities I } & 70 \\ \text { Research Universities II } & 34 \\ \text { Doctoral Granting U. I } & 51 \\ \text { Doctoral Granting U. II } & 58 \\ \text { Comprehensive U./C. I } & 424 \\ \text { Comprehensive U./C. II } & 171 \\ \text { Liberal Arts Colleges I } & 142 \\ \text { Liberal Arts Colleges II } & 430 \\ \text { Two Year Coil/Inst. } & 1,367 \\ & 2,747\end{array}$

Within each Classlfication, an institution was selected with a likelihood proportionate to the size of lts faculty when compared to other colleges/universities within the same Classification. When the sample was drawn, a few institutions were selected more than once. In these cases, the following school on the list was also selected.

For the purpose of this study, the researcher restricted data analysis to the first eight of the nine Carnegle Classiflcations. The categories have been described by the Carnegie Foundation based on the 
"level of degree offered and the comprehensiveness of their missions" (1989, pp. 147-48).

Research I institutions offer a full range of baccalaureate programs, are committed to graduate education through the doctorate degree, and give high priority to research. They receive annually at least $\$ 33.4 \mathrm{mill} 1$ on in federal support, and award at least $50 \mathrm{Ph} . \mathrm{D}$. degrees each year.

Research I I institutions offer a full range of baccalaureate programs, are committed to graduate education through the doctorate degree, and give high priority to research. They receive annually between $\$ 12.5 \mathrm{mill} 1$ on and $\$ 33.5$ million in federal support and award at least $50 \mathrm{Ph} . \mathrm{D}$. degrees each year.

Doctorate-granting I institutions offer a full range of baccalaureate programs, and their mission includes a commitment to graduate education through the doctorate degree. They award at least $40 \mathrm{Ph} . \mathrm{D}$. degrees annually in five or more academic disciplines.

Doctorate-granting I I institutions offer a full range of baccalaureate programs, and their mission includes a commitment to graduate education through the doctorate degree. They award annually 20 or more Ph.D. degrees in at least one discipline or 10 or more Ph.D. degrees in three or more disciplines.

Comprehensive I institutions offer baccalaureate programs and, with few exceptions, graduate education through the masters degree. More than half of their baccalaureate degrees are awarded in two or more occupational or professional disciplines such as engineering or business administration. All of the 
institutions in this group enroll at least 2,500 students.

Comprehensive II institutions award more than half of their baccalaureate degrees in two or more occupational or

professional disciplines, such as

engineering or business administration, and many also offer graduate education through the masters degree. All of the colleges and universities in this group enroll between 1,500 and 2,500 students.

Liberal Arts I institutions are highly selective and are primarily undergraduate colleges that award more than half of their baccalaureate degrees in arts and science fields.

Liberal Arts II institutions are primarily undergraduate colleges that are less selective and award more than half of their degrees in liberal arts fields. This category also includes a group of colleges that award less than half of their degrees in 1 iberal arts fields but, with fewer than 1,500 students, are too small to be considered comprehensive.

In the second stage of the sample design for the Carnegle Survey, faculty were designated at the selected institutions. From a data bank of American college and university faculty, 9,996 faculty members were randomly selected for the Carnegie study. The sample was equally distributed among the nine Carnegie Classifications. As part of the plan for analysis, data for each of the responses were weighted according to the Carnegie Classification and proportionate to the total number of faculty in all institutional types. 
Faculty research productivity 54

Before the actual survey, a pre-test was conducted In the fall of 1988 in whlch a draft of the questionnaire was mailed to seven college faculty and to several scholars. Based upon the results of the pre-test, the questionnaire was modified during December of 1988 and January of 1989 for the full-scale study.

The main Carnegle Survey consists of four mallings. On February 10, 1989, a preliminary letter describing the study and soliciting cooperation was mailed to the 9,996 faculty selected for the study. The survey questionnaire was mailed February 17. On February 24, a post card was mailed to all potential respondents as a reminder to complete the questionnaire. A second copy of the questionnalre was malled on March 3 , with a request to complete the questionnaire if this had not been done. The completed questionnaires were accepted for data processing through April 17. Data were entered and processed from March through May of 1989.

Of the 9,996 faculty selected for the survey, 5,450 returned their questionnaires, for a response rate of 54.5 percent. The completion rate for each of 
the elght Carnegle Classifications used in this study is as follows:

$\begin{array}{lll}\text { Research University I } & 618 & 56 \% \\ \text { Research University II } & 649 & 58 \% \\ \text { Doctoral Granting University I } & 668 & 60 \% \\ \text { Doctoral Granting University II } & 647 & 58 \% \\ \text { Comprehensive University/College I } & 623 & 56 \% \\ \text { Comprehensive University/College II } & 589 & 53 \% \\ \text { Liberal Arts I } & 691 & 62 \% \\ \text { Liberal Arts II } & 455 & 41 \%\end{array}$

A separate mailing, a postage-paid post card, was used to ask the respondents to identify themselves by name, employing institution, zip code, and faculty rank, and to ask whether the respondents did or did not hold tenure. The Carnegie Foundation received approximately 5,150 post cards from the 5,450 respondents. 
Faculty research productivity 56

\section{The Instrument}

The 1989 Carnegie Faculty Survey Questionnaire (see Appendix A) included fifty-nine questions. These questions addressed the goals of collegiate education, academic standards, attitudes about student life, teaching, research, service, status of the profession, views of the employing. institution, participation in decision-making, and general observations.

\section{Data Analysis}

This study utilized data from selected questions related to faculty research productivity included in the 1989 Carnegie Foundation Faculty Survey. The Curry School of Education at the University of Virginia purchased a copy of the data tape from the Carnegie Foundation.

For the purpose of this study, the researcher applied the statistical software package sPSS (Statistical Package for the Social Sciences) to the 1989 Carnegie Survey data for computer-based analysis. This study of faculty research productivity was restricted to include only the responses of faculty 
who indicated they had a full-time appointment for at least nine months of the academic year at the designated institution.

The twenty-nine disciplines included on the Carnegie Survey were collapsed into ten categories for this study as follows:

Biological Sciences

Agriculture/Forestry/Natural Resources

Biological/Life Sciences

Business

Business/Management

Education

Education (including Administration and

Counseling)

Physlcal and Health Education

Engi neering

Engineering

Fine Arts

Fine Arts (Art, Drama, Music)

Health Sciences

Health Professions (Dentistry, Medicine, Nursing, Veterinary)

Humanities

Forelgn Languages

Humanities (LIterature, History, Phllosophy,

Religion, Theology, Rhetorlc)

Physical Sciences

Mathematics/Statistics

Physical Sciences 
Faculty research productivity 58

Social Sciences

Area/Ethnic Studies

Economics

Geography

Psychology

Social Sciences (Anthropology, Politica) Science, Soclology, Soclal Worky

\section{Other}

Allied Health (Medical Technologies)

Architecture/Environmental Design

Communlcations/Journal ism

Computer/Information Science

Home Economics

Industrial Arts

Law

Library Science

Military Science/Technologies

Public Aftairs

Vocational/Technical Training

Other Discipline

A general demographics summary of the respondents within the study group by institutional type and

discipline is provided in Appendix B. This summary

includes the total number of respondents, the number

of males and females, and the number of respondents by academic rank and tenure status.

In order to answer the research questions, means or percentages were calculated for each category of comparison and are reported in the study. Levels of research productivity for full-time faculty by institutional type (institutional code was printed on the top of the back page of the survey), academic rank 
Faculty research productlvity 59

(survey question $\# 3,2-5$ ), discipline (survey question $\# 11,1-29$ ), tenure status (survey question $\# 2,1$ or 2), gender (survey question \#53,1 or 2), hours spent per week on research and or scholarly activities (survey question \#9, d), current engagement (survey question \#13), and receipt of internal research support (survey question \#14, a) were measured by the number of articles published in academic or professional journals (survey question \#15), the number of articles published in edited collections or volumes (survey question \#16), the number of books or monographs published or edited alone or in collaboration (survey question \#17), the number of professional writings publlshed or accepted for publication in the past two years (survey question $\# 18$ ), and the receipt of external research support within the last twelve months (survey question \#14, $b-e)$.

Stepwise multiple regression techniques were utilized to determine the amount of variance that could be attributed to the eight faculty research productivity correlates for each of the flve measures of faculty research performance. Multiple regression 
Faculty research productivity 60

assumes the respondents were randomly chosen and data were weighted to reflect the population from which the sample was drawn and assumes equal varlability or homogeneous variance. A decision was made to set the probability of entry in a stepwise regression procedure at .1 with a tolerance level of .0001 . Statistical tables are presented and descriptive summaries are provided for each of the research questions addressed in this study.

\section{Limitations}

Correlates and measures of faculty research productivity for this study are limited to related items on the 1989 Carnegie Foundation Survey of faculty. For example, intelligence scores, stress, prestige of doctoral program, mentoring, and early productivity are not used as correlates of faculty research performance, and presentations of papers at regional or national conferences cannot be used as a measure of faculty research productivity in this study, because no item on the survey instrument addresses these factors. 
Faculty research productivity 61

By analyzing the selected measures of research productivity as determined by the questions on the survey, one can conclude that the quantity of publication counts dominates the methods of measurement. In reporting the number of publications, the Carnegie survey may give equal credit to poorly written papers in badly edited journals and to well-written papers in high-quality journals (Bayer \& Folger, 1966; Smith \& Fleldler, 1971) and give equal credit to shorter and longer works. The researcher has attempted to balance the four survey questions related to the number of publications with a question that relates to external research support recelved during the past twelve months.

Another limitation of this study is the reliance on self-report data of faculty related to research productivity. In one study, Allison and Stewart (1974) estimated the rellabllity of self-reported information relative to faculty research productivity by comparing responses from chemists with publication counts from Chemical Abstracts and found the correlation was $r=.94$. 
Faculty research productivity 62

Further, no single study has been conducted using all four explanations for the variation of faculty research performance found in the literature. Therefore, existing published research provides a limited base for projecting outcomes of this study or for corroborating the results.

Finally, interpreting the results of the study is 1 imited to reporting the levels of faculty research productivity across selected research correlates and to providing explanations from the literature for the variance in individual faculty research performance based on the selected research correlates across speciflc research measures. From the selected research correlates, profiles of faculty with high levels of research performance can be determined for each measure of scholarly research. 


\section{Chapter 4}

\section{Results}

The purpose of this study was to use quantitative methods to describe the relationship between levels of faculty research productivity and institutional affiliation, academic rank, discipline, tenure status, gender, the hours per week that faculty spend on research and related scholarly activities, the current engagement of faculty in-scholarly work, and receipt of internal research support within the last twelve months. Levels of faculty research productivity as reported in the 1989 Carnegie Survey of faculty were based on the number of articles published in academic or professional journals, the number of articles published in edited collections or volumes, the number of books or monographs published or edited alone or in collaboration, the number of professional writings accepted for publication in the past two years, and the receipt of external research support within the last twelve months.

From the Carnegle data set, the researcher analyzed the responses of 4380 faculty. The faculty included in this analysis were all full-time, tenured 
Faculty research productivity 64

or non-tenured employees on at least nine-month contracts at four-year colleges and universities. Responses of these faculty were analyzed to address the following research question:

How does the level of faculty research productivity vary by institutional type? by academic rank? by discipline? by tenure status? by gender? by the number of hours spent per week on research and or scholarly activities? by current engagement in scholarly work? by internal research support?

In order to answer this primary research question, data from the 1989 Carnegie Survey of faculty were also used to address subsidiary questions as follows:

1. How many hours per week do faculty spend on research and or comparable scholarly activities?

2. What percentage of faculty is currently engaged in scholarly work that is expected to lead to a publication, an exhibit, or a musical recital?

3. What percentage of faculty has recelved internal research support during the past twelve months?

4. What is the level of faculty productivity as determined by (a) the number of articles published in academic or professional journals? (b) the number of articles published in edited collections or volumes? (c) the number of books or monographs published or edited alone, or in collaboration? (d) the number of professional writings published or accepted for publication in the past two years? 
(e) the recelpt of external research support within the last twelve months?

5. What percentage of variance in faculty research productivity can be explained by (a) institutional affiliation? (b) rank? ( $c$ ) discipline? (d) tenure status? (e) gender? ( $f$ ) hours spent per week on research and or scholarly activities? (g) current engagement in scholarly work? ( $h$ ) recelpt of internal research support?

Research Measures by Institutional Type

- In response to the primary research question concerning the level of faculty research productivity by institutional type, the mean number of publications and the percentage of faculty who received external research support within the last twelve months were calculated for each of the eight Institutional types included in this study. The following five tables (Table 1-Table 5) report these data. 
Faculty research productivity 66

Table 1

Mean No. of Articles in Academic or Professional Journals by Institutional Type

\begin{tabular}{lrrrrr}
\hline & Mean & Std Dev & Minimum & Maximum & $n$ \\
\hline RI & 29.99 & 37.07 & 0 & 325 & 549 \\
RII & 25.22 & 34.13 & 0 & 380 & 586 \\
DI & 17.48 & 26.20 & 0 & 320 & 592 \\
DII & 14.58 & 24.28 & 0 & 300 & 569 \\
CI & 9.28 & 18.03 & 0 & 300 & 532 \\
CII & 3.78 & 5.83 & 0 & 63 & 495 \\
LAI & 9.75 & 14.66 & 0 & 125 & 573 \\
LAII & 2.65 & 4.83 & 0 & 50 & 352 \\
\hline
\end{tabular}

\section{RI=Research I RII=Research II DI=Doctoral I DII=Doctoral II CI=Comprehensive I CII=Comprehensive II LA I=Liberal Arts I LA II=Liberal Arts II}

The mean number of articles published per faculty member in academic or professional journals declined, with one exception, from Research I Universities through Liberal Arts I Colleges. The publication mean for faculty in Liberal Arts I Colleges, the one anomaly in this publlcation trend, was slightly greater than the means for faculty in Comprehensive I and Comprehensive I institutions. Faculty in Research Universities, as might be expected, published at a much higher rate than faculty in other types of 
Faculty research productivity $6 ?$

institutions. This publication pattern can be understood if one considers factors such as the respective institutional missions and reward systems. The statistics indicate a high degree of variance in the scholarly productivity of faculty based on institutional afflliation.

\section{Table 2}

Mean No. of Articles in Edited Collections or Volumes by Institutional Type

\begin{tabular}{lrrrrr}
\hline & Mean & Std Dev & Minimum & Maximum & $\mathrm{n}$ \\
\hline & & & & & \\
RI & 7.02 & 11.52 & 0 & 110 & 528 \\
RII & 5.90 & 10.71 & 0 & 100 & 550 \\
DI & 4.41 & 14.03 & 0 & 208 & 557 \\
DII & 3.66 & 6.63 & 0 & 60 & 535 \\
CI & 1.83 & 3.51 & 0 & 35 & 501 \\
CII & 1.17 & 3.48 & 0 & 50 & 462 \\
LAI & 2.44 & 4.70 & 0 & 50 & 540 \\
LAII & 1.61 & 11.69 & 0 & 200 & 326 \\
\hline
\end{tabular}

\section{RI=Research I RII=Research II DI=Doctoral I DII=Doctoral II CI=Comprehensive I CI I=Comprehensive II LA I=Liberal Arts I LA II=LIberal Arts II}

The means in Table 2 follow the same publication pattern by institutional type as the means in Table 1. That is, the mean number of articles published per 
Faculty research productivity 68

faculty member in edited collections or volumes declined, with one exception, from Research I Universities through Liberal Arts I Colleges. Faculty in traditionally teaching-oriented institutions reported lower numbers of publications, on average, than faculty in research-oriented institutions reported. As in Table 1 , the mean for faculty in Liberal Arts I Colleges was higher than the means for faculty in Comprehensive I and Comprehensive II institutions. As might be expected, the mean number of articles published in edited collections or volumes (Table 2) were lower by institutional type than the means for articles published in academic or professional journals (Table 1 ). 
Faculty research productivity 69

Table 3

Mean No. of Books or Monographs Published or Edited Alone or in Collaboration by Institutional Type

\begin{tabular}{lrrrrr}
\hline & Mean & Std Dev & Minimum & Maximum & $n$ \\
\hline RI & 2.55 & 4.62 & 0 & 45 & 519 \\
RII & 2.11 & 3.72 & 0 & 35 & 556 \\
DI & 2.15 & 5.97 & 0 & 114 & 561 \\
DII & 1.74 & 9.03 & 0 & 200 & 526 \\
CI & 1.41 & 3.10 & 0 & 32 & 509 \\
CII & .88 & 2.84 & 0 & 30 & 462 \\
LAI & 1.24 & 2.61 & 0 & 40 & 537 \\
LAII & .60 & 2.16 & 0 & 25 & 324 \\
\hline
\end{tabular}

\footnotetext{
RI=Research I RII=Research II DI=Doctoral I DII=Doctoral II CI=Comprehensive I CII=Comprehensive II LA I=Liberal Arts I LA II=Liberal Arts II
}

The mean number of books or monographs published per faculty member declined from Research I Universities through Liberal Arts II Colleges, with one exception. This publication pattern can be explained by such factors as differential faculty selection and work load assignment. The mean number of publications for faculty in Liberal Arts I Colleges is greater than the mean for faculty in the Comprehensive I Institutions. Unlike Tables 1 and 2 , Table 3 Indicates that the mean number of publications for 
Faculty research productivity 70

faculty in Llberal Arts I Colleges did not surpass the mean for faculty in Comprehensive I Colleges and Universities.

Table 4

Mean No. of Professional Writings Published or Accepted for Publication in the Past Two Years by Institutional Type

\begin{tabular}{lllllll}
\hline & Mean & Std Dev & Minimum & Maximum & $n$ \\
\hline RI & 5.29 & 5.20 & 0 & 45 & 549 \\
RII & 4.52 & 5.30 & 0 & 70 & 573 \\
DI & 3.61 & 4.25 & 0 & 35 & 582 \\
DII & 2.91 & 3.52 & 0 & 30 & 564 \\
CI & 2.08 & 3.80 & 0 & 50 & 521 \\
CII & 1.11 & 1.96 & 0 & 15 & 473 \\
LAI & 2.23 & 2.88 & 0 & 25 & 566 \\
LAII & 1.06 & 3.41 & 0 & 40 & 346 \\
\hline
\end{tabular}

\section{RI=Research I RII=Research II DI=Doctoral I DII=Doctoral II CI=Comprehensive I CII=Comprehensive II LA I=Liberal Arts I LA II=Liberal Arts II}

The mean number of professional writings per faculty member published or accepted for publication in the past two years declined, with one exception, from Research I Unlversities through Liberal Arts II Colleges. The mean for faculty in Liberal Arts I Colleges was higher than the means for faculty in the 
Faculty research productivity 71

Comprehensive I and II institutions. This publication pattern was noted for Tables 1 and 2 as well. Descriptive statistics indicate, as they did in Tables $1-3$, a high degree of variance in the scholarly productivity of faculty by institutional affiliation.

\section{Table 5}

Percentage of Faculty Who Recelved External Research Support in the Past Twelve Months by Institutional Type

\begin{tabular}{|c|c|c|c|c|c|c|c|}
\hline RI & RII & DI & DI I & $\mathrm{CI}$ & CII & LAI & LAII \\
\hline $\begin{array}{r}19.1 \% \\
\langle 519\rangle\end{array}$ & $\begin{array}{r}19.5 \% \\
(544)\end{array}$ & $\begin{array}{c}13.0 \% \\
(532)\end{array}$ & $\begin{array}{c}11.8 \% \\
(507)\end{array}$ & $\begin{array}{l}7.5 \% \\
(479)\end{array}$ & $\begin{array}{l}8.4 \% \\
(439)\end{array}$ & $\begin{array}{l}10.6 \% \\
(509)\end{array}$ & $\begin{array}{l}6.4 \% \\
(299)\end{array}$ \\
\hline
\end{tabular}

\section{RI=Research I RII=Research II DI=Doctoral I \\ DII=Doctoral II $\mathrm{CI}=$ Comprehensive I CII=Comprehensive II \\ LA I=Liberal Arts I LA II=Liberal Arts II \\ *The total number of respondents is given in parentheses.}

The percentage of faculty who recelved external research support declined, overall, from those faculty employed in Research Universities through those faculty affillated with Liberal Arts Colleges. The percentage of Liberal Arts I faculty who received external research support was greater, however, than 
Faculty research productivity 72

the percentages of Comprehensive $I$ and Comprehensive I f faculty who received such support. Within the Research Universities, the percentage of faculty who received external research support in Research II Universities was slightly higher than the percentage of faculty who recelved external research support in Research I Institutions. A similar relationship can be observed in the percentages for faculty who reported the receipt of external research support in Comprehensive I and II institutions. That is, the percentage of faculty who reported the receipt of external research support was greater in Comprehensive I Colleges and Universities than in Comprehensive I institutions. The percentages of faculty who received external research support by institutional type followed the overall pattern of scholarly productivity of faculty by institutional type, reported in Tables $1-4$.

For all five of the measures of faculty research productivity utillzed in this study, levels of scholarly productivity declined, overall, from Research I Universities through Liberal Arts II Colleges. This pattern is not unexpected in terms of 
Faculty research productivity 73

the respective institutional missions and reward structures (Creswell in Finkelstein, 1985, p. 256).

Research Measures by Rank

In response to the primary research question concerning the level of faculty research productivity by academic rank, the mean number of publications per faculty member and the percentage of faculty who recelved external research support within the last twelve months were calculated for each of the four academic ranks included in this study. The following five tables (Table 6-Table 10) report these data.

\section{Table 6}

Mean No. of Articles in Academic or Professional Journals by Academic Rank

\begin{tabular}{lrrrrrr}
\hline & Mean & Std Dev & Minimum & Maximum & $n$ \\
\hline & & & & & & \\
Professor & 25.35 & 34.48 & 0 & 380 & 1769 \\
AssoProf & 9.82 & 13.35 & 0 & 220 & 1310 \\
Assiprof & 4.57 & 5.73 & 0 & 44 & 939 \\
Instructor & 1.26 & 3.15 & 0 & 30 & 137 \\
\hline
\end{tabular}

AssoProf=Assoclate Professor AssiProf=Assistant Professor 
Faculty research productivity 74

The mean number of articles published per faculty member in academic or professional journals increased from the rank of instructor through the rank of professor. Because this measure relates to cumulative research productivity, it is not surprising that faculty in the higher ranks reported, on average, higher numbers of publications. Cumulative research productivity is generally related to longevity, and longevity to higher rank. Professors publ ished, on average, two and one-half times the number of articles that assoclate professors publ ished.

\section{Table ?}

Mean No. of Articles in Edited Collections or Volumes by Academic Rank

\begin{tabular}{lrrrrrr}
\hline & Mean & Std Dev & Minimum & Maximum & $n$ \\
\hline & & & & & & \\
Prof & 5.80 & 12.15 & 0 & 208 & 1665 \\
AssoProf & 2.78 & 7.77 & 0 & 200 & 1226 \\
AssiProf & 1.54 & 3.65 & 0 & 40 & 886 \\
Instruc & .37 & 1.18 & 0 & 10 & 135 \\
\hline
\end{tabular}

Prof $=$ Professor AssoProf $=$ Assoclate Professor AssiProf=Assistant Professor Instruc=Instructor 
Faculty research productivity 75

The mean number of articles published per faculty member in edited collections or volumes increased from the rank of instructor through the rank of professor. This publication pattern was evident in Table 6 as well. Assistant professors published, on average, slightly more than four times the number of articles that instructors published, and professors, on average, published twice the number of articles that associate professors published. Faculty in the higher ranks typically have more colleagues to serve as potential collaborators for edited publlcations.

\section{Table 8}

Mean No. of Books or Monographs Published or Edited Alone or in Collaboration by Academic Rank

\begin{tabular}{lrrrrrr}
\hline & Mean & Std Dev & Minimum & Maximum & $n$ \\
& & & & & & \\
Prof & 2.61 & 6.80 & 0 & 200 & 1681 \\
AssoProf & 1.21 & 2.98 & 0 & 32 & 1232 \\
AssiProf & .59 & 1.84 & 0 & 25 & 860 \\
Instruc & .47 & $=1.66$ & 0 & 12 & 133 \\
\hline
\end{tabular}

Prof=Professor AssoProf-Associate Professor AssiProf=Assistant Professor Instruc=Instructor 
Faculty research productivity 76

The means for the number of books or monographs published per faculty member increased from the rank of instructor through the rank of professor, a publication trend noted for Tables 6 and 7 as well. The effect of rank may be related to differential work load assignment (Fulton \& Trow, 1974). At higher ranks, the teaching load is typically not as great as it is in the lower ranks. As might be expected, the mean number of publications per faculty member was less in each rank, overall, for books or monographs than for articles in academic or professional journals (Table 6) and articles in edited collections or volumes (Table 7 ). The mean number of books or monographs published per instructor, the only exception, was higher than the mean number of articles published in edited collections or volumes (Table 7 ). 
Faculty research productivity 77

Table 9

Mean No. of Professional Writings Published or Accepted for Publication in the Past Two Years by Academic Rank

\begin{tabular}{lrrrrrr}
\hline & Mean & Std Dev & Minimum & Maximum & $\mathrm{n}$ \\
\hline & & & & & & \\
Prof & 3.80 & 5.00 & 0 & 70 & 1738 \\
AssoProf & 2.60 & 3.78 & 0 & 45 & 1294 \\
AssiProf & 2.45 & 3.13 & 0 & 50 & 918 \\
Instruc & .61 & 1.35 & 0 & 8 & 135 \\
\hline
\end{tabular}

\section{Prof=Professor AssoProf=Associate Professor AssiProf=Assistant Professor Instruc=Instructor}

The means for the number of professional writings per faculty member published or accepted for publication in the past two years increased from the rank of instructor through the rank of professor. This publication pattern was also noted for Tables 6-8. The difference between the mean number of writings for assistant professors and associate professors and the difference between the maximum number of writings for these two groups was smaller than for previous types of publications (Tables 6-8). Unlike the previous publlations, this category of comparison is not cumulative over the faculty member's career. 
Faculty research productivity 78

Table 10

Percentage of Faculty Who Recelved External Research Support in the Past Twelve Months by Academic Rank

\begin{tabular}{cccc}
\hline Prof & AssoProf & AssiProf & Instruc \\
\hline $\begin{array}{c}15.5 \% \\
(1591)\end{array}$ & $\begin{array}{c}10.9 \% \\
(168)\end{array}$ & $\begin{array}{c}10.4 \% \\
(863)\end{array}$ & $\begin{array}{c}2.6 \% \\
(116)\end{array}$ \\
\hline
\end{tabular}

Prof=Professor AssoProf=Associate Professor AssiProf=Assistant Professor Instruc=Instructor

*The total number of respondents is given in parentheses.

The percentage of faculty who recelved external research support increased from the rank of instructor through the rank of professor. This trend is consistent with the pattern for the mean number of publications per faculty member as reported in Tables 6-9. The percentages of assistant and associate professors who reported the receipt of external research support are four times greater than the percentage of instructors who reported the receipt of such support. The difference in the percentages of assistant professors and associate professors who reported recelpt of external research support is 
Faculty research productivity 79

small. However, the percentage of professors who reported the recelpt of external research support is approximately one-half greater than the percentages of associate and assistant professors who reported such support. Faculty in the upper ranks may benefit from a nigher degree of visibllity than faculty in the lower ranks in securing external research support.

For all five of the measures of faculty research productivity used in this study, levels of scholarly productivity increased from the rank of instructor through the rank of professor. This trend may be explained, in part, by the reinforcement role that rank plays in the reward system for faculty in higher education (Finkelstein, 1984, p. 101).

\section{Research Measures by Discipline}

In response to the primary research question concerning the level of faculty research productivity by discipline, the mean number of publications and the percentage of faculty who recelved external research support within the last twelve months were calculated for each of the disciplinary categories in this study. 
Faculty research productivity 80

The following five tables (Table 11-Table 15) report these data.

Table 11

Mean No. of Articles in Academic or Professional Journals by

Discipline

\begin{tabular}{lrrrrr}
\hline & Mean & Std Dev & Minimum & Maximum & $\mathrm{n}$ \\
\hline BS & 25.94 & 27.67 & 0 & 200 & 306 \\
BU & 12.58 & 24.73 & 0 & 250 & 274 \\
ED & 14.60 & 24.74 & 0 & 325 & 319 \\
EN & 26.69 & 34.83 & 0 & 205 & 215 \\
FA & 4.21 & 7.22 & 0 & 50 & 339 \\
HS & 11.54 & 30.20 & 0 & 300 & 157 \\
HU & 10.17 & 18.62 & 0 & 300 & 809 \\
PS & 26.64 & 42.06 & 0 & 380 & 528 \\
SS & 14.10 & 18.11 & 0 & 150 & 697 \\
OT & 10.96 & 17.46 & 0 & 140 & 479 \\
\hline
\end{tabular}

$B S=B i o l o g i c a l$ Sciences $B U=B u s i n e s s /$ Management $E D=E d u c a t i o n$ EN=Engineering FA=Fine Arts HS=Health Sciences $\mathrm{HU}=$ Humanities PS=Physical Sclences SS=Social Sciences $\mathrm{OT}=$ Other

For faculty who reported the number of articles published in academic or professional journals, the faculty by disciplines rank as follows: ( 1 )

Engineering, (2) Physical Sciences, (3) Blological

Sciences, (4) Education, (5) Social Sciences, (6)

Business/Management, ( 7 ) Health Sciences, (8) 
Faculty research productivity 81

Humanities, (9) Other, and (10) Fine Arts. On average, faculty in the natural sciences (including Engineering) emerged as most productive; faculty in the Humanities and Fine Arts were the least productive; and Education faculty and Social Science faculty fell in between. The data indicate that scholarly productivity varies across disciplines in terms of articles published in academic or professional journals.

Table 12

Mean No. of Articles in Edited Collections or Volumes by Discipline

\begin{tabular}{rrrrrr}
\hline & Mean & Std Dev & Minimum & Maximum & $n$ \\
\hline BS & 5.67 & 11.59 & 0 & 100 & 286 \\
BU & 3.56 & 7.32 & 0 & 60 & 266 \\
ED & 2.90 & 4.94 & 0 & 40 & 295 \\
EN & 8.59 & 19.80 & 0 & 200 & 200 \\
FA & 1.80 & 12.20 & 0 & 208 & 308 \\
HS & 1.95 & 5.28 & 0 & 52 & 146 \\
HU & 3.49 & 9.61 & 0 & 200 & 768 \\
PS & 3.19 & 7.40 & 0 & 100 & 499 \\
SS & 4.31 & 7.52 & 0 & 80 & 665 \\
OT & 3.07 & 6.10 & 0 & 45 & 449 \\
\hline
\end{tabular}

$B S=B i$ logical Sciences $B U=B u s i$ ness/Management $E D=E d u c a t i o n$ $E N=E n g i n e e r i n g \quad F A=F i n e$ Arts $H S=H e a l$ th Sclences $\mathrm{HU}=$ Humanities PS=Physical Sciences SS=Social Sciences $\mathrm{OT}=$ Other 
Faculty research productivity 82

In terms of the mean number of articles published per faculty member in edited collections or volumes, the faculty by disciplines rank as follows: (1) Engineering, (2) Biological Sciences, (3) Social Sciences, (4) Business/Management, (5) Humanities, (6) Physical Sciences, (7) Other, (8) Education, (9) Health Sclences, and (10) Fine Arts. As in Table 11 , Engineering faculty ranked first in the mean number of publications and Fine Arts faculty ranked last. Otherwise, the rank order for faculty in Table 2 was different from that in Table 1. Disciplines differ in their coauthorship patterns (Gaston, 1978) and in the division of labor on scholarly works that require various collaborators (Gaston, 1978). Faculty in some disciplines, such as the natural sciences, tend to co-author publications at a higher rate than faculty in other disciplines, such as Education and the Fine Arts. 


\section{Faculty research productivity 83}

\section{Table 13}

Mean No. of Books or Monographs Published or Edited Alone or in Collaboration by Discipline

\begin{tabular}{lrrrrr}
\hline & Mean & Std Dev & Minimum & Maximum & $n$ \\
\hline & & & & & \\
BS & .80 & 1.66 & 0 & 18 & 283 \\
BU & 1.86 & 4.10 & 0 & 30 & 261 \\
ED & 2.94 & 8.07 & 0 & 114 & 301 \\
EN & 1.15 & 3.59 & 0 & 45 & 195 \\
FA & 1.35 & 4.31 & 0 & 40 & 309 \\
HS & .71 & 1.29 & 0 & 8 & 146 \\
HU & 2.01 & 3.21 & 0 & 35 & 767 \\
PS & .89 & 2.29 & 0 & 25 & 491 \\
SS & 2.21 & 8.35 & 0 & 200 & 669 \\
OT & 1.59 & 3.18 & 0 & 31 & 449 \\
\hline
\end{tabular}

$\mathrm{BS}=\mathrm{B} \operatorname{lol} \operatorname{logi} \mathrm{cal}$ Sciences BU=Business/Management $\mathrm{ED}=$ Educat $\mathrm{i}$ on $\mathrm{EN}=$ Engineering $\mathrm{FA}=\mathrm{Fine}$ Arts HS=Health Sciences HU=Humanities PS=Physical Sciences SS=Social Sciences $\mathrm{OT}=0$ ther

Concerning the mean number of books or monographs published per faculty member, the faculty by disciplines rank as follows: (1) Education, (2) Social Sciences, (3) Humanities, (4) Business/Management, (5) Other, (6) Fine Arts, (7) Engineering, (8) Physical Sciences, (9) Biological Sciences, and (10) Health Sciences. Engineering faculty, who reported the highest publication levels in Table 11 and Table 12 , 
Faculty research productivity 84

rank seventh in the mean number of books or monographs published per faculty member. Fine Arts faculty, who reported the lowest publication levels in the previous two tables, rank sixth in terms of the mean number of books or monographs published. Disciplines vary according to their paradigmatle stage in terms of the form of publications required (Biglan, 1973). For paradigmatic disciplines, such as the natural sciences, shorter forms of publications--journal articles--are accepted (Table 11). In pre-paradigmatic disciplines, such as Education, lengthened communication forms--books and monographs--are required (Biglan). 
Faculty research productivity 85

Table 14

Mean No. of Professlonal Writings Published or Accepted for Publication in the Past Two Years by Discipline

\begin{tabular}{llllll}
\hline & Mean & Std Dev & Minimum & Maximum & $n$ \\
\hline BS & 4.33 & 6.35 & 0 & 70 & 301 \\
BU & 2.69 & 3.31 & 0 & 25 & 271 \\
ED & 3.05 & 3.95 & 0 & 28 & 312 \\
EN & 4.64 & 5.20 & 0 & 28 & 211 \\
FA & 1.37 & 3.11 & 0 & 40 & 325 \\
HS & 2.16 & 3.14 & 0 & 20 & 153 \\
HU & 2.86 & 3.94 & 0 & 50 & 802 \\
PS & 3.53 & 4.96 & 0 & 40 & 519 \\
SS & 3.23 & 3.88 & 0 & 45 & 691 \\
OT & 2.66 & 3.47 & 0 & 35 & 468 \\
\hline
\end{tabular}

$B S=B l o l o g l c a l$ Sclences $B U=B u s i n e s s /$ Management $E D=E d u c a t i o n$ EN=Engineering $F A=F i n e$ Arts $H S=H e a l$ th Sciences $\mathrm{HU}=$ Humanities PS=Physical Sciences SS=Social Sciences $\mathrm{OT}=\mathrm{O}$ ther

In terms of the number of professional writings published or accepted for publication per faculty member in the past two years, the faculty by disciplines rank as follows: (1) Engineering; (2) Biological Sciences; ( 3 ) Physical Sciences; (4) Social Sciences; (5) Education; (6) Humanities; (7) Business/ Management; (8) Other; (9) Health Sclences; and (10) Fine Arts. As in Table 11, on average, faculty in the 
Faculty research productivity 86

natural sciences emerged as most productive; faculty in the Humanities and Fine Arts were the least productive; and Education faculty and Social Science faculty fell in between. The paradigmatic stage of a discipline affects scholarly research in terms of acceptance rates in Journals (Gaston, 1978). In disciplines such as the natural sciences in which the knowledge is codifled to a high degree, the acceptance rates are high. Further, in paradigmatic disciplines, abbreviated forms of scholarly publications are accepted.

Table 15

Percentage of Faculty Who Recelved External Research Support by Discipline

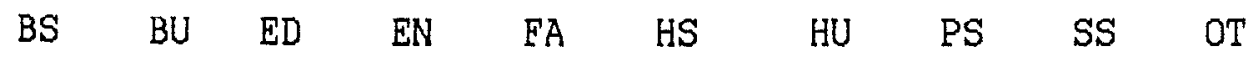

$21.3 \% \quad 9.5 \% \quad 12.6 \% \quad 22.2 \% \quad 11.9 \% \quad 15.8 \% \quad 8.9 \% \quad 12.8 \% \quad 11.1 \% \quad 13.1 \%$ (296) (242) (269) (198) (302) (139) (710) (501) (633) (434)

$B S=B \operatorname{lological~Sciences~BU=Business/Management~} E D=E d u c a t i o n$ $E N=$ Engl neering $F A=F i n e$ Arts HS=Health Sciences HU=Humanities PS=Physical Sciences SS=Social Sciences $\mathrm{OT}=$ Other

*The total number of respondents is given in parentheses. 
Faculty research productivity 87

The rank order of disciplines in which, faculty reported the recelpt of external research support is as follows: (1) Engineering; (2) Biologlcal Sciences;

(3) Health Sclences; (4) Other; (5) Physical Sciences;

(6) Education; (7) Fine Arts; (8) Social Sciences; (9) Business/Management; and (10) Humanities. Approximately 22 percent of Engineering faculty received external research support, while almost 9 percent of faculty in the Humanities recelved such support. Grant receipt depends primarlly on faculty research productivity (Liebert, 1976), which may help to explain why faculty in the natural sciences emerged as most productive, overall, in terms of the receipt of external research support.

Engineering faculty ranked first in four out of the five measures of scholarly productivity (Tables 11, 12, 14, and 15). The mean number of books or monographs published (Table 13 ) was the only measure for which Engineerlng faculty failed to rank first. Faculty in the Blologlcal sciences ranked second in three of the five measures of research productivity-number of articles in edited collections or volumes (Table 12), number of articles published or accepted 
Faculty research productivity 88

for publication in the past two years (Table 14), and the receipt of external research support (Table 15). Business/Management faculty ranked fourth in the mean number of articles published in edited collections or volumes (Table 12) and in the mean number of books or monographs published (Table 13). Fine Arts faculty had the lowest productivity levels of any disciplinary group in terms of articles published in academic or professional journals (Table 11), articles published in edited collections or volumes (Table 12), and professional writings published or accepted for publication in the past two years (Table 14). Faculty in the Biological Sciences ranked second in the mean number of articles published in edited collections or volumes (Table 12) and in the mean number of professional writings published or accepted for publication in the past two years (Table 14).

Variance in research performance among the ten disciplinary categories is evident for each of the flve measures of faculty research productivity. Furthermore, variation in the level of faculty scholarly productivity may be noted in terms of the rank of a disciplinary category across the five 
Faculty research productivity 89

measures of research performance. However, on the whole, faculty in the natural sciences emerged as most productive and faculty in the Humanities and Fine Arts were the least productive.

Research Measures by Tenure Status

In response to the primary research question concerning the level of faculty research productivity by tenure status, the mean number of publications and the percentage of faculty who received external research support within the last twelve months were calculated for tenured and non-tenured faculty in this study. The following five tables (Table 16-Table 20) report these data.

Table 16

Mean No. of Articles in Academic or Professional Journals by Tenure Status

Mean Sta Dev Minimum Maximum n

\begin{tabular}{lrrrrr}
\hline Tenured & 18.57 & 28.74 & 0 & 380 & 3041 \\
Non-tenured & 5.59 & 12.09 & 0 & 300 & 1207 \\
\hline
\end{tabular}


The mean number of articles published per faculty member in academic or professional journals was three times higher for tenured faculty than for" non-tenured faculty. Tenured faculty typically have been in the profession longer than have non-tenured faculty. Because this measure of faculty research productivity is a cumulative measure, it is not surprising that the number of publications reported by tenured faculty was much higher, on average, than the number of publications reported by non-tenured faculty.

Table 17

Mean No. of Articles in Edited Collections or Volumes by Tenure Status

\begin{tabular}{lrrrrrr}
\hline & Mean & Std Dev & Minimum & Maximum & $n$ \\
\hline Tenured & 4.36 & 10.00 & 0 & 208 & 2857 \\
Non-tenured & 1.93 & 7.21 & 0 & 200 & 1142 \\
\hline
\end{tabular}

The mean number of articles published per faculty member in edited collections or volumes was more than twice as large for tenured faculty than for non-tenured faculty. This overall publication trend 
Faculty research productivity 91

was noted for Table 16 as well. Edited collections very often Include revisions of manuscripts that were previously published in academic or professional journals. Therefore, tenured faculty who publ ished, on average, three times as many articles in academic or professional journals as non-tenured faculty published (Table 16) would have an advantage in this measure of scholarly productivity (Table 17).

Table 18

Mean No. of Books or Monographs Published or Edited Alone or in Collaboration by Tenure Status

\begin{tabular}{lrrrrr}
\hline & Mean & Std Dev & Minimum & Maximum & $n$ \\
\hline Tenured & 2.01 & 5.61 & 0 & 200 & 2875 \\
Non-tenured & .73 & 2.08 & 0 & 25 & 1119 \\
\hline
\end{tabular}

Consistent with the publication pattern indicated in Tables 16 and 17 , the mean number of books or monographs published or edited per faculty member is higher for faculty with tenure than for faculty without tenure. Tenured faculty, on average, reported more than twice the number of publications that 
Faculty research productivity 92

non-tenured faculty reported. However, considering the length of books and monographs and the professional

status and orlentation of non-tenured faculty

(Chronister, Baldwin, \& Bailey, 1991), non-tenured

faculty, on average, indicated a respectable number of publications.

\section{Table 19}

Mean No. of Professional Writings Published or Accepted for Publication in the Past Two Years by Tenure Status

\begin{tabular}{llccccc}
\hline & Mean & Std Dev & Minimum & Maximum & $n$ \\
\hline Tenured & 3.24 & 4.56 & 0 & 70 & 2987 \\
Non-tenured & 2.35 & 3.17 & 0 & 40 & 1187 \\
\hline
\end{tabular}

Table 19 reports that the mean number of professional writings published or accepted per faculty member for publication in the past two years is higher for tenured faculty than for non-tenured faculty. This trend was inherent in Tables 16-18 as well. While the descriptive statistics in Tables 16-19 indicate a high degree of varlation in the level of faculty scholarly productivity by tenure status, the 
Faculty research productivity 93

gap between the means for the two cohorts is narrower for this category of comparison.

Table 20

Percentage of Faculty Who Recelved External Research Support by Tenure Status

\begin{tabular}{cc}
\hline Tenured & Non-tenured \\
\hline $13.2 \%$ & $10.8 \%$ \\
$(2719)$ & $(1109)$ \\
\hline
\end{tabular}

*The total number of respondents is given in parentheses.

Consistent with the pattern of faculty scholarly productivity indicated in Tables $16-19$, the percentage of faculty who received external research support was higher for tenured faculty than for non-tenured faculty. The non-tenured faculty, however, have done well on this variable. Tenured faculty reported higher levels of scholarly productivity than non-tenured faculty indicated for the five measures of faculty research productivity reported in this study (Tables $16-20>$. 
Faculty research productivity 94

Research Measures by Gender

In response to the primary research question concerning the level of faculty research productivity by gender, the mean number of publications and the percentage of faculty who received external research support within the last twelve months were calculated for males and females in this study. The following five tables (Table 21-Table 25) report these data.

Table 21

Mean No. of Articles in Academic or Professional Journals by Gender

\begin{tabular}{lrrrrrr}
\hline & Mean & Std Dev & Minimum & Maximum & $n$ \\
\hline Males & 17.93 & 28.41 & 0 & 380 & 3130 \\
Females & 6.31 & 13.33 & 0 & 300 & 1104 \\
\hline
\end{tabular}

The mean number of articles published per faculty member in academic or professional journals was almost three times greater for males than for females. Some of this variance can be explained by the distribution of faculty across institutional types. Females are employed disproportionately in traditionally 
Faculty research productivity 95

teaching-oriented institutions (See Appendix B).

Respective missions and reward systems of institutions lead to differential work load assignment.

Table 22

Mean No. of Articles in Edited Collections or Volumes by Gender

\begin{tabular}{lrrrrrr}
\hline & Mean & Std Dev & Minimum & Maximum & $n$ \\
\hline Males & & & & & & \\
Females & 4.27 & 10.44 & 0 & 208 & 2952 \\
& 1.93 & 4.72 & 0 & 70 & 1035 \\
\hline
\end{tabular}

In terms of the mean number of articles published per faculty member in edited collection or volumes, the level of publication was over twice as high for males as for females. One explanation for the variation in faculty research productivity by gender is that women do not have access to the "old boy" network and are not privy to information belng exchanged (Creswell in Finkelstein, 1985, p. 242). Males may have a larger network of different collaborators, interacting on specific tasks. 
Faculty research productivity 96

Table 23

Mean No. of Books or Monographs Published or Edited Alone or in Collaboration by Gender

\begin{tabular}{lrrrrrr}
\hline & Mean & Std Dev & Minimum & Maximum & $n$ \\
\hline Males & 1.81 & 4.10 & 0 & 114 & 2960 \\
Females & 1.00 & 2.63 & 0 & 40 & 1021 \\
\hline
\end{tabular}

The mean number of books or monographs published per faculty member was higher for males than for females. This publication pattern had been noted previously for Tables 1 and 2 . However, for the mean number of books or monographs published, the difference between males and females was not as large as the difference in means for the previous two measures of faculty research productivity (Tables 1 and 2). Females, on average, had one book or monograph published, while males had less than two books or monographs published. 
Faculty research productivity 97

Table 24

Mean No. of Professional Writings Published or Accepted for Publication in the Past Two Years by Gender

\begin{tabular}{llrrrrr}
\hline & Mean & Std Dev & Minimum & Maximum & $n$ \\
\hline Males & 3.31 & 4.58 & 0 & 70 & 3093 \\
Females & 2.07 & 2.82 & 0 & 30 & 1068 \\
\hline
\end{tabular}

The publlcation pattern indlcated in Table 24 was consistent with the trend found in Tables 21-23. That is, the mean number of articles published or accepted for publication in the past two years per faculty member was greater for males than for females. The measures of faculty research productivity in Tables 21-23 were cumulative over a faculty member's career, while the data in Table 24 reflect a publication trend over the past two years. In terms of the data reported in Tables 21-24, females may be more recently narrowing the gap with males in terms of publication differences. 
Faculty research productivity 98

Table 25

Percentage of Faculty Who Recelved External Research Support by Gender

\begin{tabular}{ll}
\hline Males & Females \\
\hline $12.9 \%$ & $11.2 \%$ \\
$(2856)$ & $(961)$ \\
\hline
\end{tabular}

*The total number of respondents is given in parentheses.

A slightly hlgher percentage of males received external research support during the past twelve months than females did. Because grant receipt--a salient source of external research support--depends primarily on faculty research productivity (Liebert, 1976) and there is compelling evidence that males publish more than females (Astin, 1984, 1969), it is not surprising that a greater percentage of males receive external research support than do females. However, the difference in the percentages between males and females in Table 25 is not large. While females may be closing the gap with males in terms of some publication measures, males rated higher than 
Faculty research productivity 99

females on all of the five measures of research performance utillzed in this study.

Research Measures by Hours per Week Spent on

Research/Scholarly Activities

In response to the primary research question concerning the level of faculty research productivity by hours spent per week on research and or scholarly activities, the mean number of publications and the percentage of faculty who recelved external research support within the last twelve months were calculated for the hours per week spent on research and or scholarly activities (scaled) in this study. The following five tables (Table 26-Table 30 ) report these data.

Table 26

Mean No. of Articles in Academic or Professional Journals by Hours Spent Per Week on Research and/or Scholarly Activities

\begin{tabular}{lrrrrr} 
Hrs./Wk. & Mean & Std Dev & Minimum & Maximum & $n$ \\
\hline 10 or less & 9.31 & 16.93 & 0 & 300 & 2053 \\
$11-20$ & 18.39 & 22.55 & 0 & 205 & 984 \\
$21-30$ & 27.79 & 37.93 & 0 & 380 & 429 \\
$31-40$ & 37.36 & 45.57 & 0 & 320 & 190 \\
41 or more & 36.36 & 53.30 & 0 & 310 & 98 \\
\hline
\end{tabular}


Faculty research productivity 100

The mean number of articles published per faculty member in academic or professional journals increased, overall, as the number of hours spent per week on research and/or scholarly activities increased. Faculty who spent more than 40 hours per week, the only exception, had a slightly lower level of publication than faculty who spent 31 to 40 hours per week had.

Table 27

Mean No. of Articles in Edited Collections or Volumes by Hours Spent Per Week on Research and/or Scholarly Activities

\begin{tabular}{lrrrrr} 
Hrs./Wk. & Mean & Std Dev & Minimum & Maximum & $\mathrm{n}$ \\
\hline 10 or less & 2.42 & 7.43 & 0 & 208 & 1922 \\
$11-20$ & 4.64 & 9.85 & 0 & 200 & 936 \\
$21-30$ & 5.98 & 9.85 & 0 & 70 & 406 \\
$31-40$ & 8.56 & 18.39 & 0 & 200 & 189 \\
41 or more & 7.85 & 13.67 & 0 & 100 & 94 \\
\hline
\end{tabular}

The mean number of articles published per faculty member in edited collections increased, with one exception, as the number of hours spent per week on research and or scholarly activities increased. Faculty who spent more than 40 hours per week had a 
Faculty research productivity 101

lower level of publication than faculty who spent 31 to 40 hours per week did. This publication trend was indicated in Table 26 as well. Spending too little or too much time on research activities may impair faculty scholarly productivity (Pelz \& Andrews, 1966).

\section{Table 28}

Mean No. of Books or Monographs Published or Edited Alone or in Collaboration by Hours Spent Per Week on Research and/or Scholarly Activities

\begin{tabular}{lrrrrr} 
Hrs./Wk. & Mean & Std Dev & Minimum & Maximum & n \\
\hline 10 or less & 1.31 & 3.82 & 0 & 114 & 1935 \\
$11-20$ & 2.08 & 3.84 & 0 & 40 & 932 \\
$21-30$ & 2.11 & 3.99 & 0 & 32 & 398 \\
$31-40$ & 2.26 & 4.38 & 0 & 45 & 178 \\
41 or more & 2.46 & 4.55 & 0 & 35 & 92 \\
\hline
\end{tabular}

The mean number of books or monographs published or edited alone or in collaboration per faculty member increased as the number of hours spent per week on research andor scholarly activities increased. The amount of time faculty spend on research has been found to be a important predictor of high research productivity (Allison \& Stewart, 1974). 
Faculty research productivity 102

Table 29

Mean No. of Professional Writings Published or Accepted for Publication in the Past Two Years by Hours Spent Per Week on Research and/or Scholarly Activities

\begin{tabular}{lrrrrr}
\hline Hrs./Wk. & Mean & Std Dev & Minimum & Maximum & $n$ \\
\hline 10 or less & 1.87 & 2.78 & 0 & 40 & 2019 \\
$11-20$ & 4.17 & 4.54 & 0 & 50 & 970 \\
$21-30$ & 5.56 & 5.26 & 0 & 45 & 427 \\
$31-40$ & 5.92 & 5.34 & 0 & 30 & 187 \\
41 or more & 6.46 & 8.68 & 0 & 70 & 97 \\
\hline
\end{tabular}

The mean number of professional writings published or accepted for publication in the past two years per faculty member increased as the number of hours spent on research and or scholarly activities increased. This research pattern is consistent with the publication trend indicated in Table 28, even though the previous productivity measure was cumulative over a faculty member's career. As indicated by the data, the amount of time spent on research/scholarly activities appears to be directly related to the level of faculty research productivity for both measures of research performance ( $T a b l e s 28$ and 29). 
Faculty research productivity 103

Table 30

Percentage of Faculty Who Received External Research Support by Hours Spent Per Week on Research and/or Scholarly Activities

\begin{tabular}{rrrrrr} 
Hrs./Wk. 10 or less & $11-20$ & $21-30$ & $31-40$ & 41 or more \\
$\begin{array}{r}8.7 \% \\
(1829)\end{array}$ & $\begin{array}{c}15.9 \% \\
(900)\end{array}$ & $\begin{array}{r}20.0 \% \\
(409)\end{array}$ & $\begin{array}{r}23.9 \% \\
(176)\end{array}$ & $\begin{array}{r}21.5 \% \\
(93)\end{array}$ \\
\hline
\end{tabular}

*The total number of respondents is given in parentheses.

The percentage of faculty who received external support increased as the number of hours spent per week on research andror scholarly activities increased, up to 40 hours per week. The percentage of faculty who received external research support was lower for faculty who spent more than 40 hours per week on research/scholarly activitles than for faculty who spent $31-40$ hours per week.

The levels of faculty research productivity for the flve measures of research performance increased, overall, as the number of hours spent per week on research and or scholarly activities increased. Faculty who spent more than 40 hours per week on research/scholarly activities had lower levels of 
scholarly productivity than faculty who spent 31 to 40 hours per week for three of the measures of research performance (Tables 26,27 , and 30 ).

Research Measures by Current Engagement in Scholarly Work

In response to the primary research question concerning the level of faculty research productivity by current engagement in scholarly work, the mean number of publications and the percentage of faculty who received external research support within the last twelve months were calculated for the faculty who were currently engaged in scholarly work and for the faculty who were not currently engaged in such actlvity. The following five tables (Table 31-Table 35) report these data.

Table 31

Mean No. of Articles in Academic or Professional Journals by Current Engagement in Scholarly Work

\begin{tabular}{lrrrrr} 
Currently Engaged & Mean & Std Dev & Minimum & Maximum & $n$ \\
\hline Yes & 17.20 & 27.56 & 0 & 380 & 3518 \\
No & 3.72 & 8.42 & 0 & 90 & 730
\end{tabular}


Faculty research productivity 105

The mean number of articles published per faculty member in academic or professional journals was over four times higher for faculty who were currently engaged in scholarly work than for faculty who were not currently engaged in such activity. Because this is a cumulative measure of publication, it is possible for faculty not to be engaged in scholarly work and still have publications to their credit. However, the time spent on research and or scholarly activities has been found to be an important predictor of high research productivity (Allison \& Stewart, 1974; Tables 26-30). It is not surprising, therefore, that faculty who are currently engaged in scholarly work have reported, on average, substantially higher numbers of publications.

Table 32

Mean No. of Articles in Edited Collections or Volumes by Engagement in Scholarly Work

Currently Engaged Mean Std Dev Minimum Maximum n

\begin{tabular}{lrrrrr}
\hline Yes & 4.29 & 10.13 & 0 & 208 & 3306 \\
No & .71 & 2.13 & 0 & 25 & 693 \\
\hline
\end{tabular}


Faculty research productivity 106

Table 32 indicates a publication level six times greater for faculty who are currently engaged in research and or scholarly activities than for faculty who are not engaged in scholarly work. This publication trend was noted for articles published in academic or professional journals as well (Table 31). Faculty who are currently engaged in research activity and published, on average, four times as many articles in academic or professional journals as faculty who were not engaged in scholarly activity had published (Table 31) would have a big advantage in this measure of scholarly productivity (Table 32 ).

\section{Table 33}

Mean No. of Books or Monographs Published or Edited Alone or in Collaboration by Engagement in Scholarly Work

\begin{tabular}{lrrrrr} 
Currently Engaged & Mean & Std Dev & Minimum & Maximum & $n$ \\
\hline Yes & 1.89 & 5.33 & 0 & 200 & 3295 \\
No & .54 & 1.67 & 0 & 20 & 699 \\
\hline
\end{tabular}

The mean number of books or monographs published per faculty member was more than three times greater 
for faculty who were engaged in scholarly work than for faculty who were not engaged in such activity. Not surprisingly, faculty published fewer books or monographs than articles in academlc or professional journals (Table 31) or articles in edited collections or volumes (Table 32). Because books and monographs are lengthier forms of communication, they require more time. Therefore, it is not surprising that the difference in mean number of publications is substantial between faculty who are currently engaged in scholarly work and faculty who are not currently engaged in such activity.

Table 34

Mean No. of Professional Writings Published or Accepted for Publication in the Past Two Years by Engagement in Scholarly Work

Currently Engaged Mean Std Dev Minimum Maximum n

\begin{tabular}{lrrrrr}
\hline Yes & 3.52 & 4.43 & 0 & 70 & 3467 \\
No & .37 & 1.08 & 0 & 10 & 707 \\
\hline
\end{tabular}


Faculty research productivity 108

years was almost ten times higher for faculty who were currently engaged in scholarly work than for faculty who were not currently engaged in such activity. Because this measure of research performance is a recent measure, as opposed to a cumulative measure, it is not surprising that faculty who are not currently engaged in scholarly work have such few publications to their credit in the past two years. However, a mean publication rate of 3.52 for the past two years for faculty who are currently engaged in scholarly work is very impressive. This mean for the 3467 faculty who indicated current engagement in scholarly work approaches the mean number of professional writings published or accepted for publication in the past two years of Doctorate I University faculty (Table 4).

\section{Table 35}

Percentage of Faculty Who Received External Research Support by Engagement in Scholarly Work

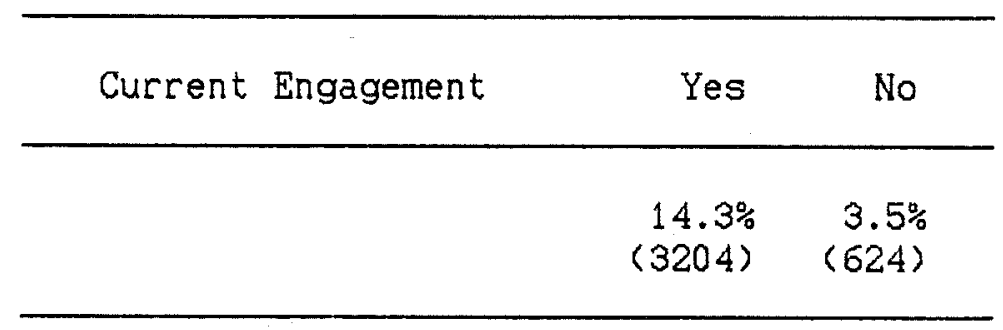

*The total number of respondents is given in parentheses. 
Faculty research productivity 109

For faculty who reported the recelpt of external research support, the percentage of faculty currently engaged in scholarly work was four times greater than the percentage of faculty not currently engaged in such activity. This pattern of scholarly productivity by current engagement in scholarly work has been noted for the five measures of research performance (Tables 31-35). Engagement or non-engagement in scholarly work Is an important determinant of the level of faculty research productivity.

\section{Research Measures by Internal Research Support}

In response to the primary research question concerning the level of faculty research productivity by internal research support received during the past twelve months, the mean number of publications and the percentage of faculty who received external research support within the last twelve months were calculated for faculty who had received internal research support and for faculty who had not received such support. The following five tables (Table 36-Table 40) report these data. 
Faculty research productivity 110

$$
\text { Table } 36
$$

Mean No. of Articles in Academic or Professional Journals by Receipt of Internal Research Support

Internal Research Support Mean Std Dev Minimum Maximum $n$

$\begin{array}{llllll}\text { Yes } & 17.16 & 24.80 & 0 & 310 & 2010 \\ \text { No } & 11.61 & 23.31 & 0 & 325 & 1835\end{array}$

The mean number of articles published per faculty member in academic or professional journals was 47 percent higher for faculty who recelved internal research support than for faculty who did not receive such research support. The data indicate a positive relationship between internal research support and the level of faculty research productivity.

Table 37

Mean No. of Articles in Edited Collections or Volumes by Receipt of Internal Research Support

Internal Research Support Mean Std Dev Minimum Maximum n Yes

No

2.58

6.78

0

$208 \quad 1892$

$0 \quad 110 \quad 1739$ 
Faculty research productivity 111

The mean number of articles published per faculty member in edited collections of volumes was 65 percent greater for faculty who recelved internal research support than for faculty who did not recelve such support. While the faculty were almost evenly divided (Tables 36 and 37 ) between those who had received internal research support and those who had not recelved such support, the majority of faculty reported the receipt of internal research support.

Table 38

Mean No. of Books or Monographs Published or Edited Alone or in Collaboration by Receipt of Internal Research Support

Internal Research Support Mean Std Dev Minimum Maximum n

\begin{tabular}{llllrl}
\hline Yes & 1.77 & 3.46 & 0 & 40 & 1883 \\
No & 1.48 & 6.27 & 0 & 200 & 1756
\end{tabular}

The mean number of books or monographs published or edited per faculty member was hlgher for faculty who recelved internal research support than for faculty who did not receive such assistance. The difference between the mean number of publications 
Faculty research productivity 112

for both cohorts was much smaller than the difference between the publications means for the previous two measures of scholarly productivity (Tables 36 and 37). The data suggest that the receipt of internal research support may not be as directly related to the mean number of books or monographs published as It is to the mean number of journal articles published (Table 36) or the mean number of articles published in edited collections (Table 37).

\section{Table 39}

Mean No. of Professional Writings Published or Accepted for Publication in the Past Two Years by Receipt of Internal

Research Support

Internal Research Support Mean Std Dev Minimum Maximum n

\begin{tabular}{llllll} 
Yes & 3.83 & 4.35 & 0 & 50 & 1990 \\
No & 2.12 & 3.92 & 0 & 70 & 1798 \\
\hline
\end{tabular}

The mean number of professional writings per faculty member published or accepted for publication in the past two years was higher for faculty who recelved internal research support than for faculty who did not recelve such support. While this measure 
Faculty research productivity 113

of faculty research productivity is not cumulative, the data indicate a publication trend that is consistent with the pattern noted for the three previous measures of faculty research performance $($ Tables 36-38).

Table 40

Percentage of Faculty Who Received External Research Support by Receipt of Internal Research Support

\begin{tabular}{rrr}
\hline Internal Research Support & Yes & No \\
\hline & $16.8 \%$ & $.3 \%$ \\
$(1758)$ & $(1882)$ \\
\hline
\end{tabular}

*The total number of respondents is given in parentheses.

Faculty who recelved external research support also received internal research support in a higher proportion than faculty who did not recelve external research support did. This pattern of research productivity by receipt of internal research support has been noted for the five measures of research performance (Tables 36-40) used in this study. The receipt of internal research support has been related 
Faculty research productivity 114

to higher levels of faculty research productivity in the five categories of comparison.

Hours Spent per Week on Research/Scholarly Activities by Research Correlates

In response to the first subsidiary research question concerning the number of hours faculty spend per week on research and or comparable scholarly activities, the mean number of hours was calculated by institutional affiliation, gender, tenure status, discipline, rank, current engagement, and the receipt of internal research support. The following seven tables (Table 41-47) report these data. Hours spent per week are scaled as indicated in the tables. 
Faculty research productivity 115

Table 41

Mean Hours/Week Spent on Research/Scholarly Activity by Institutional Type

\begin{tabular}{lrrrrr}
\hline & Mean & Std Dev & *Minimum & +Maximum & $n$ \\
\hline RI & 21.49 & 14.20 & 1 & 5 & 538 \\
RII & 18.21 & 11.21 & 1 & 5 & 553 \\
DI & 15.71 & 11.85 & 1 & 5 & 554 \\
DII & 14.17 & 11.20 & 1 & 5 & 519 \\
CI & 10.36 & 9.18 & 1 & 5 & 478 \\
CII & 7.57 & 7.25 & 1 & 5 & 423 \\
LAI & 12.05 & 11.02 & 1 & 5 & 517 \\
LAII & 6.53 & 7.79 & 1 & 5 & 266 \\
\hline
\end{tabular}

\begin{abstract}
$R I=$ Research I RII=Research II DI=Doctoral I
DII=Doctoral II CI=Comprehensive I CII=Comprehensive II LA I=Liberal Arts I LA II=Liberal Arts II

* $1=10$ or less hours per week $+5=41$ or more hours per week
\end{abstract}

The mean number of hours per week spent per faculty member on research andor scholarly activities declined, overall, from Research I Universities through Liberal Arts II Colleges. The mean for faculty in Liberal Arts I Colleges, the one exception, was greater than the means for faculty in Comprehensive institutions. 
Faculty research productivity 116

Table 42

Mean Hours/Week Spent on Research/Scholarly Activity by Gender

\begin{tabular}{lrrrrrr}
\hline & Mean & Std Dev & *Minimum & +Maximum & $\mathrm{n}$ \\
\hline Males & 14.91 & 11.89 & 1 & 5 & 2868 \\
Females & 11.29 & 11.49 & 1 & 5 & 969 \\
\hline
\end{tabular}

* $1=10$ or less hours per week $+5=41$ or more hours per week

The mean number of hours per week spent per faculty member on research and or scholarly activities was 32 percent greater for males than for females. The relationship between the mean and standard deviation for each of the two groups indicates a higher degree of variation for females than for males in the number of hours spent per week on research activitles. 
Faculty research productivity 117

Table 43

Mean Hours/Week Spent on Research/Scholarly Activity by Tenure Status

\begin{tabular}{lrrrrrr}
\hline & Mean & Std Dev & *Minimum & +Maximum & $n$ \\
\hline Tenured & 14.20 & 11.80 & 1 & 5 & 2773 \\
Non-tenured & 13.43 & 12.09 & 1 & 5 & 1075 \\
\hline
\end{tabular}

* $1=10$ or less hours per week $+5=41$ or more hours per week

The mean number of hours per week spent per faculty member on research and/or scholarly activities was slightly higher for faculty who were tenured than for faculty who were non-tenured. The means were surprisingly close in relation to the means for productivity measures reported earlier in this study (Tables $16-20)$. 
Faculty research productivity 118

Table 44

Mean Hours/Week Spent on Research/Scholarly Activity by

Discipline

\begin{tabular}{lrrrrr}
\hline & Mean & Std Dev & *Minimum & +Maximum & $n$ \\
\hline BS & 19.28 & 14.62 & 1 & 5 & 290 \\
BU & 13.69 & 10.27 & 1 & 5 & 243 \\
ED & 10.25 & 9.74 & 1 & 5 & 278 \\
EN & 16.92 & 11.10 & 1 & 5 & 200 \\
FA & 12.15 & 10.50 & 1 & 5 & 313 \\
HS & 9.88 & 11.95 & 1 & 5 & 142 \\
HU & 12.73 & 10.88 & 1 & 5 & 748 \\
PS & 16.74 & 13.21 & 1 & 5 & 483 \\
SS & 15.84 & 12.63 & 1 & 5 & 645 \\
OT & 11.78 & 9.87 & 1 & 5 & 425 \\
\hline
\end{tabular}

$\mathrm{BS}=\mathrm{Biological}$ Sclences $\mathrm{BU}=$ Business/Management $\mathrm{ED}=$ Education $E N=$ Engineering $F A=F$ ine Arts $\mathrm{HS}=\mathrm{Heal}$ th Sclences HU=Humanities PS=Physical Sciences SS=Soclal Sciences $\mathrm{OT}=$ Other

* $1=10$ or less hours per week $+5=41$ or more hours per week

In terms of the mean number of hours per week spent per faculty member on research and or scholarly activities, the faculty by disciplines rank as follows: (1) Biological Sciences; (2) Engineering;

(3) Physical Sciences; (4) Social Sciences; (5) Business/ Management; (6) Humanitles; (7) Fine Arts; (8) Other; (9) Education; and (10) Health Sciences. 
Faculty research productivity 119

Faculty in the natural sciences rank highest, as they did in the measures of research performance (Tables 11-15), in terms of the time spent per week on research. Health Sclence faculty, who ranked last in this category, ranked last or next to last in three of the five performance measures (Tables 12-14).

Education faculty, who ranked ninth in this category of comparison, were in the top one-half of the ten disciplinary classifications of faculty in three of the five performance measures (Tables 11-15).

\section{Table 45}

Mean Hours/Week Spent on Research/Scholarly Activity by Rank

Mean Std Dev *Minimum +Maximum n

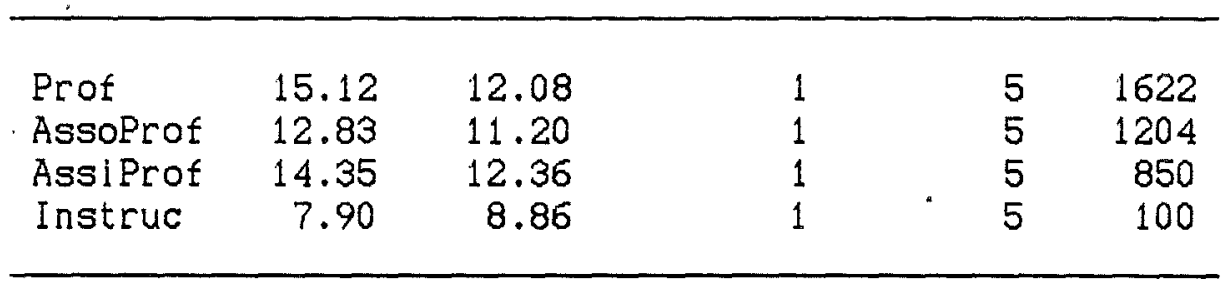

Prof=Professor AssoProf=Associate Professor AssiProf=Assistant Professor Instruc=Instructor * $1=10$ or less hours per week $+5=41$ or more hours per week 
The mean number of hours per week spent per faculty member on research and or scholarly activities varied by rank. Assistant professors spent more hours per week per faculty member than did associate professors but less than professors.

Table 46

Mean Hours/Week Spent on Research/Scholarly Activity by Current Engagement

\begin{tabular}{lrrrrr} 
Current Engagement & Mean & Std Dev & *Minimum & +Maximum & $n$ \\
\hline Yes & 15.39 & 11.99 & 1 & 5 & 3354 \\
No & 4.46 & 4.59 & 1 & 4 & 494 \\
\hline
\end{tabular}

* $1=10$ or less hours per week $+4=31-40$ hours per week $+5=41$ or more hours per week

The mean number of hours per week spent per faculty member on research and or scholarly activities was almost three and one-half times greater for faculty currently engaged in scholarly work that was expected to lead to a publication, an exhibit, or a musical recital than for faculty not currently engaged in research/ scholarly activities with such expectations. Thls is the only measure for 
Faculty research productivity 121

which a cohort of faculty reported spending a maximum of no more than 40 hours per week on research/ scholarly activities.

\section{Table 47}

Mean Hours/Week Spent on Research/Scholarly Activity by Receipt of Internal Research Support

\begin{tabular}{llllll} 
Internal Support & Mean & Std Dev & *Minimum & tMaximum & $n$ \\
\hline Yes & 16.44 & 12.36 & 1 & 5 & 1941 \\
No & 10.98 & 10.53 & 1 & 5 & 1574 \\
\hline
\end{tabular}

* $1=10$ or less hours per week $+5=41$ or more hours per week

The mean number of hours per week spent per faculty member on research and or scholarly activities was 49.7 percent greater for faculty who had recelved internal research support than for faculty who had not recelved such support. Because the receipt of internal research support (Tables 36-40) and the increased number of hours spent per week on scholarly activities (Tables 26-30) were indicative of higher levels of faculty research productivity, these data are not surprising. 
Faculty research productivity 122

Percentage of Faculty Engaged in Scholarly Work by Research Correlates

In response to the second subsidiary research question concerning the percentage of faculty currently engaged in scholarly work that is expected to lead to a publication, an exhibit, or a musical recital, percentages of faculty engaged and percentages of faculty not engaged were calculated by institutional affiliation, gender, tenure status, discipline, rank, hours per week spent on research/scholarly activities (scaled), and the receipt of internal research support. The following seven tables (Table 48-Table 54) report these data.

\section{Table 48}

Percentage of Faculty Currently Engaged in Scholarly Activities by Institutional Type

$\begin{array}{llll}\text { Research I } & 95.9 \% & (562) \\ \text { Research II } & 93.3 \% & (598) \\ \text { Doctoral I } & 90.6 \% & (607) \\ \text { Doctoral I } & 86.8 \% & (583) \\ \text { Comprehensive I } & 75.8 \% & (554) \\ \text { Comprehensive II } & 65.3 \% & (516) \\ \text { Liberal Arts I } & 82.1 \% & (592) \\ \text { Liberal Arts II } & 58.4 \% & (368)\end{array}$

*The total number of respondents is glven in parentheses. 
Faculty research productivity 123

The percentage of faculty members currently engaged in scholarly work that is expected to lead to a publication, an exhibit, or a musical recital declined, with one exception, from Research I Universities through Liberal Arts II Colleges. A greater percentage of faculty in Liberal Arts I institutions were currently engaged in scholarly work than were faculty in Comprehensive institutions. The trend indicated in Table 48 for current faculty engagement in scholarly activity by institutional type follows the pattern reported in Tables $1-5$ and Table 41 for six categories of comparison by institutional type.

Table 49

Percentage of Faculty Currently Engaged in Scholarly Activities by Gender

$\begin{array}{lll}\text { Male } & 84.4 \% & (3212) \\ \text { Female } & 77.3 \% & (1151)\end{array}$

*The total number of respondents is given in parentheses.

The percentage of faculty members currently engaged in scholarly work that is expected to lead to 
a publication, an exhibit, or a muslcal recital is greater for males than for females. The trend indicated in Table 49 for current engagement in scholarly activity by gender follows the pattern reported in Tables 21-25 and Table 42 for the categories of comparison by gender. In this study, males have had higher means or percentages than females in every category of comparison.

\section{Table 50}

Percentage of Faculty Currently Engaged in Scholarly Activities by Tenure Status

$\begin{array}{lll}\text { Tenured } & 83.0 \% & (3134) \\ \text { Non-tenured } & 81.0 \% & (1246)\end{array}$

*The total number of respondents is glven in parentheses.

The percentage of faculty members currently engaged in scholarly work that is expected to lead to a publication, an exhibit, or a musical recital is slightly greater for faculty who are tenured than for faculty who are not tenured. The trend indicated in Table 50 for current engagement in scholarly activity by tenure status follows the pattern reported in 
Faculty research productivity 125

Tables 16-20 and Table 43 for the categories of comparison by tenure status. That is, tenured faculty have consistently ranked above non-tenured faculty in all measures of comparison. However, in Tables 19, 43, and 50, the difference between the means or percentages for the two cohorts is relatively small compared to the difference between the means or percentages for the two groups in other categories of comparison (Tables $16,17,18,20)$. In terms of the mean number of professional writings published or accepted for publication in the past two years, the mean number of hours spent per faculty member each week on research/scholarly activities, and the percentage of faculty currently engaged in scholarly work, data for non-tenured faculty were very close to the statistics for tenured faculty. 
Faculty research productivity 126

Table 51

Percentage of Faculty Currently Engaged in Scholarly Activities by Discipline

Biological Sciences

Business/Management

Education

Engineer ing

Fine Arts

Heal th Sciences

Humanities

Physical Sciences

Social Sciences

other
$86.8 \%$ (311)

$77.4 \%$ (283)

$76.6 \%$ (325)

$88.9 \%$ (216)

$89.4 \%$ (378)

$84.6 \% \quad(162)$

$83.5 \%$ (838)

$79.5 \% \quad(533)$

$90.1 \%$ (707)

$76.3 \%$ (497)

*The total number of respondents is given in parentheses.

In terms of the percentage of faculty members currently engaged in scholarly work that is expected to lead to a publication, an exhibit, or a musical recital, the faculty by disciplines rank as follows: (1) Social Sciences; (2) Fine Arts; (3) Engineerlng; (4) Biological Sciences; (5) Health Sciences; (6) Humanities; (7) Physical Sciences; (8) Business) Management; (9) Education; and (10) Other. The Social Sciences faculty, who ranked first in Table 51, have held rankings more in the middle of the faculty by discipline in previous tables. The Fine Arts faculty, 
who ranked second in Table 51, have consistently ranked in the lower half of the faculty by discipline in previous tables. Engineering faculty, who have consistently ranked near the top among faculty in the ten disciplines--first in Tables $11,12,14$, and 15 , and second in Table 44--ranked third in Table 51.

Table 52

Percentage of Faculty Currently Engaged in Scholarly Activities by Rank

$\begin{array}{lll}\text { Professor } & 84.8 \% & (1818) \\ \text { Associate Professor } & 82.7 \% & (1355) \\ \text { Assistant Professor } & 83.2 \% & (968) \\ \text { linstructor } & 58.5 \% & (142)\end{array}$

*The total number of respondents is given in parentheses.

The percentage of faculty currently éngaged in scholarly work that is expected to lead to a publication, an exhibit, or a musical recital increased, overall, from the rank of instructor through professor. The percentage of assistant professors was higher relative to engagement than the percentage of assoclate professors was. The pattern indicated for current engagement in Table 52 
Faculty research productivity 128

follows the pattern reported in Table 45 . In terms of the mean hours per week spent per faculty member on research/scholarly activities (Table 45) and the percentage of faculty currently engaged in scholarly work (Table 52), the means or percentages increase, except for assistant professors, from instructor through professor. In Table 52, the percentage of instructors engaged in scholarly work is far behind the percentages of faculty in the three higher ranks engaged in such activity. The percentages of faculty engaged in scholarly work in the three highest ranks are clustered very closely.

Table 53

Percentage of Faculty Currently Engaged in Scholarly Activities

by Hours per Week Spent on Research/Scholarly Activities

10 or Less Hours per Week

11-20 Hours per Week

21-30 Hours per Week

31-40 Hours per Week

41 or More Hours per Week 100.0\%
(2109)

(1010)

(437)

(194)

(98)

*Total number of respondents is given in parentheses. 
Faculty research productivity 129

The percentage of faculty currently engaged in scholarly work that is expected to lead to a publication, an exhibit, or a musical recital increased as the number of hours per week spent on research and or scholarly activities increased. At least 97 percent of faculty who spent more than ten hours per week on research/scholarly activities expected their efforts to lead to publications, exhibits, or recitals. All of the faculty who spent more than forty hours per week on research and or scholarly activities had these expectations. The majority of faculty $(54.8 \%)$ reported spending ten or less hours per week on research/scholarly activities.

In terms of time spent on research and or scholarly activities and productivity measures, Tables 28 and 29 indicate the same pattern as Table 53. That is, as the number of hours per week spent per faculty member on research/scholarly activities increased, the levels of research productivity for faculty increased. Tables 26,27 , and 30 also indicate increased levels of faculty scholarly productivity as the number of hours per week spent per faculty member increased, up to a point. For 
Faculty research productivity 130

faculty who spent more than 40 hours per week on research/scholarly activities, the means or percentages of research productivity decreased.

\section{Table 54}

Percentage of Faculty Currently Engaged in Scholarly Activities by Receipt of Internal Research Support

Internal Research Support No Internal Research Support
$95.2 \% \quad(2052)$

$71.6 \%(1895)$

*The total number of respondents is glven in parentheses.

The percentage of faculty who were currently engaged in research andior scholarly work was over 13 percent higher for faculty who received internal research support than for faculty who had not recelved such support. The trend indicated in Table 54 in terms of the receipt of internal research support is reported in Tables $31-35$ and Table 47 . For every category of comparison related to internal research support, levels of research productivity were higher for faculty who received internal research support than for faculty who had not recelved such support. 
Faculty research productivity 131

\section{Internal Research Support by Research Correlates}

In response to the third subsidiary research question concerning the percentage of faculty recelving internal research support during the past twelve months, percentages were calculated by institutional affiliation, gender, tenure status, discipline, rank, current engagement, and hours per week spent on research/scholarly activities (scaled). The following seven tables (Table 55-Table 61) report these data.

Table 55

Percentage of Faculty who Received Internal Research Support by Institutional Type

$\begin{array}{lll}\text { Research I } & 58.6 \% & (502) \\ \text { Research II } & 61.3 \% & (530) \\ \text { Doctoral I } & 57.1 \% & (559) \\ \text { Doctoral II } & 52.8 \% & (527) \\ \text { Comprehensive I } & 43.6 \% & (505) \\ \text { Comprehensive II } & 38.5 \% & (460) \\ \text { Liberal Arts I } & 60.4 \% & (545) \\ \text { Liberal Arts II } & 34.5 \% & (319)\end{array}$

*The total number of respondents is given in parentheses. 
Faculty research productivity 132

The percentage of faculty who received internal research support was greatest for faculty employed in Research II Universities $(61.3 \%)$. Liberal Arts I Colleges ranked second in the percentage of faculty who reported the receipt of Internal research support $(60.4 \%)$. Otherwise, the percentage of faculty who recelved internal research support declined from Research Universities through Liberal Arts Colleges. Tables $1-5,41$, and 48 indicated faculty in Liberal Arts I Colleges exceeded faculty in Comprehensive institutions in categories of comparison by institutional type. However. Table 55 is the first table to report Liberal Arts I faculty exceeding Doctorate Granting University faculty in a category of comparison.

Table 56

Percentage of Faculty Who Recelved Internal Research Support by Gender

$\begin{array}{lll}\text { Male } & 53.5 \% & (2899) \\ \text { Female } & 48.1 \% & (1035)\end{array}$

*The total number of respondents is given in parentheses. 
A greater percentage of male faculty recelved Internal research support than did female faculty. This trend is consistent with the research performance pattern indicated in Tables 21-25, 42, and 49. Males have indlcated higher levels of faculty research productivity across all categories of comparison.

\section{Table 57}

Percentage of Faculty Who Received Internal Research Support by Tenure Status

$\begin{array}{lll}\text { Tenured } & 51.2 \% & (2800) \\ \text { Non-tenured } & 53.8 \% & (1147)\end{array}$

*The total number of respondents is given in parentheses.

The percentage of faculty who received internal research support was greater for tenured faculty than for non-tenured faculty. This trend is consistent with the pattern Indicated in Tables $16-20,43$, and 50. Tenured faculty have reported higher levels of research productivity than non-tenured faculty in every category of comparison. 
Faculty research productivity 134

Table 58

Percentage of Faculty by Discipline who Received Internal Research Support

*The total number of respondents is given in parentheses.

In terms of the percentage of faculty who received internal research support, the faculty by disciplines rank as follows: (1) Biological Sciences; (2) Social Sciences; (3) Fine Arts; (4) Engineering;

(5) Physical Sciences; (6) Humanities and Health Sciences; (7) Other; (8) Business/Management; and (9) Education. Faculty in the Biological Sciences cranked first in Tables 58 and 44 ) are 10 percentage points ahead of faculty in Social Sciences (ranked second) and 30 percentage points above Education faculty (ranked last) relative to the receipt of internal 
Faculty research productivity 135

research support. Faculty in Humanities and Health

Sclences tied for sixth place among faculty by

discipline who received internal research support.

While this is the first category of comparison in

which Education faculty ranked last, they did rank

ninth in two categories (Table 44 and 51) Physical

Scientists and Business/Management faculty held the same rankings--fifth and next to last, respectively--for the receipt of external research support (Table 15) and for the receipt of internal research support (Table 58).

Table 59

Percentage of Faculty Who Received Internal Research Support by Rank

Professor

Associate Professor

Assistant Professor

Instructor
$53.7 \%(1619)$

$49.7 \%(1220)$

$56.5 \% \quad(894)$

$35.2 \%$ (125)

*The total number of respondents is given in parentheses.

The percentage of faculty that received internal research support is higher for assistant professors than for professors and is greater for associate 
Faculty research productivity 136

professors than for instructors. This pattern indicated in Table 59 for the recelpt of internal research support differs from the trend in all other categories of comparison by rank. Levels of faculty research productivity increased from the rank of instructor through the rank of professor (Tables 6-10). The mean number of hours spent each week per faculty member on research/scholarly activities (Table 45) and the percentage of faculty engaged in scholarly work (Table 52) increased, overall, from the rank of instructor through professor. Assistant professors had a higher mean (Table 45) and percentage (Table 52) than assoclate professors.

Table 60

Percentage of Faculty Who Received Internal Research Support by Current Engagement

Currently Engaged

Not Currently Engaged
$59.0 \%$

$15.4 \%$
(3310)

(637)

*The total number of respondents is given in parentheses.

The percentage of faculty who received internal research support was almost four times greater for 
faculty who were currently engaged in scholarly work than for faculty who were not currently engaged in such activity. In all categories of comparison, the means or percentages for faculty currently engaged in scholarly work were greater than those for faculty not engaged in such activity (Tables $31-35,46$, and 54).

Table 61

Percentage of Faculty Who Received Internal Research Support by Hours per Week Spent on Research/Scholarly Activities

$\begin{array}{llr}10 \text { or Less Hours per Week } & 45.6 \% & (1923) \\ 11-20 \text { Hours per Week } & 64.7 \% & (930) \\ 21-30 \text { Hours per Week } & 67.0 \% & (397) \\ 31-40 \text { Hours per Week } & 72.8 \% & (173) \\ 41 \text { or More Hours per Week } & 77.2 \% & (92)\end{array}$

*The total number of respondents is given in parentheses.

The percentage of faculty that received internal research support increased as the number of hours per week spent per faculty member on research/scholarly activities increased. This trend was indicated in Table 53. The same pattern could be observed in Tables 26-30, up to a point. Faculty who spent more 
Faculty research productivity 138

than 40 hours per week on research and or scholarly activities had lower levels of research productivity than faculty who spent 31-40 hours per week had. Less than one-half of the faculty who indicated they spent ten or less hours per week on scholarly activities received internal research support, while more than one-half of the faculty who spent more than'ten hours per week on research and or scholarly activities received such support.

\section{Levels of Faculty Research Productivity}

What is the level of faculty productivity as determined by (a) the number of articles published in academic or professional journals? (b) the number of articles published in edited collections or volumes? (c) the number of books or monographs published or edited alone, or in collaboration? (d) the number of professional writings published or accepted for publication in the past two years? (e) the receipt of external research support within the last twelve months? To answer subsidiary research question four, levels of faculty research productivity were calculated by institutional affiliation, gender, 
tenure status, discipline, rank, current engagement, hours per week spent on research/scholarly activities (scaled), and the recelpt of internal research support. The data for these levels of faculty research productivity have been reported previously in this study as follows:

(a) articles published in academic or professional journals--Tables $1,6,11,16,21,26,31,36$, 41,46 ;

(b) articles published in edited collections or volumes-Tables $2,7,12,17,22,27,32,37,42$, 47 ;

(c) books or monographs published or edited alone, or in collaboration--Tables $3,8,13,18,23,28$, 33,38 ;

(d) professional writings published or accepted for publication in the past two years--Tables 4,9 , $14,19,24,29,34,39,44,49$; and

(e) receipt of external research support within the last twelve months--Tables $5,10,15,20,25,30$, 35,40 .

\section{Multiple Regression}

What percentage of variance in faculty research productivity can be explained by institutional affiliation, rank, discipline, tenure status, gender, hours spent per week on research and or scholarly activities, current engagement in scholarly work, and the receipt of internal research support? In order to 
Faculty research productivity 140

answer this final subsidiary research question, stepwise multiple regression techniques were employed for each of five measures of faculty research performance used in this study. A decision was made to set the probability of entry in a stepwise regression procedure at .1 with a tolerance level of .0001 . The following five tables (Table 62-Table 66) report these data.

\section{Table 62}

Multiple Regression Summary Table: Articles Published in Academic or Professional Journals

\begin{tabular}{lcccc}
\hline Predictors & Multiple R & Rsq & F(Eqn) & SigF \\
& & & & \\
Rank & .3588 & .1288 & 486.948 & .000 \\
Hrs./Wk. & .4631 & .2145 & 449.768 & .000 \\
Carnegie & .5018 & .2518 & 369.323 & .000 \\
Engagement & .5047 & .2547 & 281.252 & .000 \\
Gender & .5070 & .2570 & 227.680 & .000 \\
Discipline & .5084 & .2584 & 191.091 & .000 \\
Tenure Status & .5090 & .2591 & 164.275 & .000 \\
& & & & \\
\hline
\end{tabular}

A multiple correlation of .51 was obtained between the criterion measure, number of articles published in academic or professional journals, and 
Faculty research productivity 141

seven of the eight predictors. Approximately 26 percent of the variance in the number of journal publications was explained by the predictors. Rank was found to be the highest correlate, accounting for approximately 13 percent of the variation. Recelpt of internal research was the only variable that falled to enter the regression equation $(p \geq .1)$.

Table 63

Multiple Regression Summary Table: Articles in Edited Collections or Volumes

\begin{tabular}{lrlrl}
\hline Predictors & Multiple R & Rsq & F(Eqn) & SigF \\
& & & & \\
Rank & .1914 & .0366 & 118.670 & .000 \\
Hrs./Wk. & .2543 & .0647 & 107.858 & .000 \\
Carnegie & .2746 & .0754 & 84.776 & .000 \\
Engagement & .2818 & .0794 & 67.215 & .000 \\
Tenure Status & .2847 & .0811 & 54.993 & .000
\end{tabular}

A multiple correlation of .28 was obtained between the criterion measure, number of articles published in edited collections or volumes, and five of the eight predictors, indicating that approximately 8 percent of the variance in the number 
Faculty research productivity 142

of edited publications was explained by the predictors. Rank, as in Table 62, accounted for the greatest amount of variance (approximately 4 percent). Discipline, gender, and receipt of internal research support falled to enter the regression equation $(p \geq .1)$.

Table 64

Multiple Regression Summary Table: Books or Monographs Published or Edited Alone or in Collaboration

\begin{tabular}{lrrrr}
\hline Predictors & Multiple R & Rsq & F(Eqn) & SigF \\
\hline Rank & .2085 & .0435 & 141.667 & .000 \\
Carnegie & .2331 & .0543 & 89.487 & .000 \\
Engagement & .2443 & .0597 & 65.920 & .000 \\
\hline
\end{tabular}

A multiple correlation of .24 was obtained between the criterion measure, number of books or monographs published or edited alone or in collaboration, and three of the eight predictors, indicating that approximately 6 percent of the variance in the number of publications was explained by the predictors. As in Tables 62 and 63 , rank was the highest correlate. This varlable accounted for 
Faculty research productivity 143

approximately 4 percent of the variance. Discipline, tenure status, recelpt of internal research support, gender, and hours spent per week on research/ scholarly activities were variables which falled to enter the regression equation $(p \geq .1)$.

\section{Table 65}

Multiple Regression Summary Table: Professional Writings Published or Accepted for Publication in the Past Two Years

\begin{tabular}{lcccc}
\hline Predictors & Multiple R & Rsq & F(Egn) & SigF \\
\hline Hrs./Wk. & .3366 & .1133 & 415.953 & .000 \\
Carnegie & .3842 & .1476 & 281.882 & .000 \\
Engagement & .4059 & .1647 & 213.893 & .000 \\
Rank & .4229 & .1789 & 177.169 & .000 \\
Internal Support & .4277 & .1830 & 145.651 & .000 \\
Tenure Status & .4287 & .1838 & 122.034 & .000 \\
& & & & \\
\hline
\end{tabular}

A multiple correlation of .43 was obtained between the criterion measure, number of professional writings published or accepted for publication in the past two years, and six of the eight predictors, indicating that approximately 18 percent of the variance in the number of publications or acceptances was explained by the predictors. The number of hours 
Faculty research productivity 144

spent per week on research and or scholarly activities was the highest correlate. Approximately 11 percent of the variance for this category was explained by the time spent on research/scholarly activities. Discipline and gender failed to enter the regression equation $(p \geq .1\rangle$.

Table бб

Multiple Regression Summary Table: Receipt of External Research Support

\begin{tabular}{lllll} 
Predictors & Multiple R & Rsq & F(Eqn) & SigF \\
\hline & & & & \\
Internal Support & .2847 & .0810 & 273.415 & .000 \\
Hrs./Wk. & .2952 & .0871 & 147.914 & .000 \\
Rank & .2990 & .0894 & 101.400 & .000 \\
Discipline & .3019 & .0911 & 77.652 & .000 \\
Carnegie & .3036 & .0921 & 62.869 & .000 \\
Tenure Status & .3051 & .0931 & 52.950 & .000 \\
& & & & \\
\hline
\end{tabular}

A multiple correlation of .31 was obtalned between the criterion measure, the receipt of external research support, and six of the eight predictors. Approximately 9 percent of the variance in the receipt of external research support was explained by the predictors. Receipt of internal 
Faculty research productivity 145

research support was the hlghest correlate for the receipt of external research support. The receipt of internal research support accounted for approximately 8 percent of the variance. Gender and current engagement were the varlables which failed to enter the regression equation $(p \geq .1\rangle$.

Rank was the highest correlate for three of the research measures (Tables 62-64), the fourth hlghest correlate for the measure in Table 65, and the third highest correlate for the measure in Table 66. The number of hours per week spent per faculty member on scholarly work was the highest correlate for the research measure in Table 65 and the second highest correlate for the measures in Tables 62,63 , and 66 . Type of institution was a significant predictor ( $p \leq .1$ ) for all five of the research measures (Tables 62-66). Current engagement in research/scholarly activities was a signlficant predlctor $(p \leq .1)$ for all of the research measures except the receipt of external research support (Table 66). The number of articles published in academic or professional journals (Table 62) was the only research measure for which gender was a significant predictor $(p \leq .1)$. The 
Faculty research productivity 146

number of books or monographs published (Table 64) was the only research measure for which tenure status was not a significant predictor $(p \geq .1)$. Discipline was a significant predictor $(p \leq .1)$ for two of the five research measures, articles published in academic or professional journals (Table 62) and receipt of external research support (Table 66). The receipt of internal research support was the highest correlate for the receipt of external research support (Table 66) and a significant predictor ( $p \leq .1$ ) for the number of professional writings published or accepted for publication within the past two years (Table 65).

In terms of the percentage of variance for which the eight predictors accounted; the measures of research performance rank as follows: (1) articles published in academic or professional journals (26\%);

(2) professional writings published or accepted for publication within the past two years $(18 \%)$; (3) recelpt of external research support $(9 \%) ;(4)$ articles published in edited collections or volumes ( $8 \%$ ): and (5) books or monographs publ ished ( $6 \%$ ). 


\section{Chapter 5}

\section{Summary and Discussion}

While faculty research productivity has been the topic of more than one hundred studies conducted since 1940, no single study has included correlates from all four of the explanations found in the literature for the variation in faculty research performance (Creswe 11, 1985a, p. 241; Wood, 1990, p. 83). Further, numerous studies of faculty research productivity have falled to account adequately for factors such as institutional affiliation, academic rank, discipline, tenure status, and gender (Creswell, 1985, vil). Faliure to account for such factors has posed limitations to faculty and academic administrators who

need to translate research findings into practice. The purpose of this study was twofold: to examine individual faculty research productivity in terms of the relationship between and among factors selected from all four of the explanations found in the literature for the varlance in faculty research productivity; and to control for factors such as institutional affiliation in order to facilitate the 
Faculty research productivity 148

utilization of results of this study by faculty and academic administrators.

In this study, the researcher utllized self-report data from the 1989 Carnegie Survey of the professoriate of full-time, tenured and non-tenured faculty employed in Research Universities, Doctoral Granting Universities, Comprehensive Colleges and Universities, and Llberal Arts Colleges. Individual faculty research performance was studied by institutional affiliation, academic rank, discipline, tenure status, gender, the number of hours per week spent on research and/or scholarly activities, current engagement in scholarly work, and the receipt of internal research support in the past twelve months. Studying faculty research performance' in this manner incorporated the four explanations found in the literature for the variation in research productivity--psychological-individual factors, cumulative advantage, reinforcement, and disciplinary norms. Self-report data relative to the number of articles published in academic or professional journals, number of articles published in edited collections or volumes, number of books or monographs published or edited alone or in 
Faculty research productivity 149

collaboration, number of professional writings published or accepted for publication in the past two years, and receipt of external research support were used as measures of research performance.

Because of the high degree of variance in faculty research productivity (Allison, 1980; Fox, 1983; Robbins et al, 1986 ) and an aggressive movement observed from the early 1980 s to increase the importance of faculty research performance as a criterion for academic personnel decision-making (Bowen \& Schuster, 1985, p. 14; Seldin, 1984), the researcher controlled for such factors as institutional afflliation, rank, discipline, and gender. The researcher also disaggregated the data reported in this study in a manner that would facilitate its use by faculty and academic administrators--presidents, deans, chairs--and personnel committees who review faculty credentials from different departments and disciplines.

A comparison between the levels of individual faculty research productivity across institutional types in this study indicates, on the whole, a predictable decrease in performance levels as one moves from Carnegie Classiflcations one through elght (1.e.) 
Faculty research productivity 150

from Research I to Research II to Doctorate I to Doctorate II to Comprehensive I to Comprehensive II to Liberal Arts I to Liberal Arts II). Notable exceptions include faculty in the Liberal Arts I institutions. For each category of comparison, faculty in Liberal Arts I institutions ranked higher, with one exception, than faculty in Comprehensive I and II institutions. Liberal Arts I faculty did not report higher publication levels than Comprehensive I faculty for books or monographs. Other exceptions are the Doctoral I faculty, who ranked higher than Research II faculty on the mean number of books or monographs published or edited by faculty. Finally, faculty in Research I institutions did not rank the highest in all categories of comparison. In terms of the percentage of faculty who recelved external research support and the percentage of faculty who had received internal. research support within the last twelve months, Research I institutions ranked second and third, respectively. This overall pattern of variation in faculty research productivity by institutional type is not unexpected in terms of the respective institutional missions and reward structures (Creswell in Finkelstein, 1985, p. 256). When regressed 
with the other seven correlates of faculty research productivity, institutional afflilation was found to be a significant predictor ( $p \leq .1$ ) for all five measures of research performance.

In terms of institutional afflilation, the results of this study corcoborate Kim's (1990) findings in a recent study of the effects of organizational context characteristics on the research performance of chemistry faculty. Kim found that organizational context advantages, such as the research or ientedness of the affiliated institution, were related to high faculty research productivity.

The levels of individual faculty research productivity across four ranks--professor, associate professor, assistant professor, and instructor--varied as expected (Blackburn, Behymer \& Hall, 1978; Creswell, 1985, p.'40; Fulton \& Trow, 1974). Overall, the levels of research productivity increased with higher ranks. Assistant professors did rank higher than associate professors in terms of hours per week spent per faculty member on research/scholarly activities, current engagement in scholarly work, and receipt of internal research support. A high percentage of assistant 
Faculty research productivity 152

professors seeking promotion and or tenure may help explain why they may be engaged in scholarly work and spending more time than associate professors on research. When regressed with the other seven correlates of faculty research productivity used in this study, rank was found to be a significant predictor $(p \leq .1)$ for each of the five measures of research performance. Rank was the highest correlate for three research measures (Tables 62-64). This trend may be explained, in part, by the reinforcement rale that rank plays in the reward system for faculty in higher education (Finkelstein, 1984, p. 101).

For each of the five measures of scholarly productivity used in this study, levels of research productivity increased from the rank of instructor through the rank of professor. It is not surprising that faculty in the higher ranks reported, on average, higher numbers of publications. Three of the four publication measures were cumulative. Cumulative research productivity is generally related to longevity, and longevity to higher rank.

Results of this study corroborate the findings of earlier studies relative to the rank order of faculty 
Faculty research productivity 153

research productivity for three disciplinary categorles--natural sciences, soclal sciences, and the humanities (Biglan, 1973; Finkelstein, 1984, p. 100; Wanner, Lewis, \& Gregorio, 1981). One exception can be noted. In terms of the mean number of books or monographs published or edited, Education faculty in this study ranked first and were followed by faculty in Social Sciences, Humanlties, Business/Management, and Fine Arts. In pre-paradigmatic disciplines, such as education, books and monographs are required (Biglan. 1973).

The results of this study indicate that faculty in the Biological Sciences and the Social Sciences received internal research support in greater percentages than in any other disciplinary group, while faculty in Engineering and the Biological Sciences reported the recelpt of external research support in greater percentages. Blological Sciences, Engineering, Physical Sciences, and Social Sciences were the disclplines which had the highest mean numbers of hours per week spent per faculty member on research/scholarly activities. Faculty in Social Sciences, Fine Arts, and 
Faculty research productivity 154

Englneering reported the highest level of current engagement in research and or scholarly activities.

While earlier studies found that the paradigmatic stage of a discipline affects scholarly research (Lodahl \& Gordon, 1972) in terms of acceptance rates in journals (Gaston, 1978) and the form of communication (Biglan, 1973), in this study discipline was found to be a significant predictor $(p \leq .1\rangle$ for only two of the five measures of research performance--the number of articles published in academic or professional journals and the recelpt of external research support. Disclpline was found to be an insigniflcant predictor $(p \geq .1)$ for the number of articles published in edited collections or volumes, the number of books or monographs published or edited alone or in collaboration, and the number of professional writings published or accepted for publication in the past two years.

The levels of research productivity for tenured faculty in this study were higher than those for non-tenured faculty in every category of comparison. These findings would seem to substantiate Alstyne's (1985, p. 167) observation that the function of tenure 
Faculty research productivity 155

is to encourage and maximize scholarly activity. When regressed with the other seven research correlates utilized in this study, tenure status was found to be a significant predictor $(p \leq .1)$ for four of the five measures of faculty research productivity--number of articles published in academic or professional journals, number of articles published in edited collections or volumes, number of professional writings published or accepted for publication in the past two years, and recelpt of external research support. Tenure status was not found to be a significant predictor $\langle p \geq .1\rangle$ for the number of books or monographs published or edited.

The results of this research add to the compelling evidence presented in previous studies that males publish more than females (Astin, 1984, 1969; Babchuk \& Bates, 1962; Cole, J. 1979; Cole \& Zuckerman, 1984; Hargens, McCann, \& Reskin, 1978). Male faculty reported higher levels of research productivity than female faculty reported in every category of comparison. However, when regressed with the other seven correlates of faculty research performance used in this study, gender was found to be an insignificant 
Faculty research productivity 156

predictor $(p \geq .1\rangle$ for four of the five measures of research performance. Gender was found to be a significant predictor $(p \leq .1)$ for the number of articles published in academic or professional journals. Findings from this study corroborate results from previous studies pertaining to the relationship between gender and research performance: while gender helps to explain variations in the quantity of faculty research publications (Rosenfeld, 1987), it is, comparatively, an insignificant correlate of faculty research performance (Bernard, 1964; Blackburn, Behymer, \& Hall, 1978; Cameron \& Blackburn, 1981; Cole \& Zuckerman, 1984).

The levels of faculty research productivity increased, overall, as the mean number of hours per week spent per faculty member on research and or scholarly activities increased. As faculty reported spending more time on research activitles, the mean number of books or monographs publ ished or edited and the number of professlonal writings published or accepted for publication within the last two years increased. The mean number of articles published in academic or professional journals, the mean number of 
articles published in edited collections or volumes, and the percentage of faculty who received external research support increased as the number of hours spent per week on research/scholarly activities increased, up to forty hours per week. These means or percentages declined for faculty who indicated they spent forty-one hours or more per week on research. This finding corroborates an earlier study conducted by Pelz \& Andrews (1966), which reported that spending too much time on research activities can hamper research productivity. As the number of hours faculty reported spending per week on research/scholarly activities increased, the percentages of faculty who reported the receipt of internal research support within the past twelve months and current engagement in research/scholarly activities also increased.

The number of hours per week spent per faculty member on research/scholarly activities was found to be a significant predictor $(p \leq .1)$ for four of the five measures of faculty research productivity used in this study--number of articles published in academic or professional journals, number of articles published in edited collections or volumes, number of articles 
published or accepted for publication within the last two years, and receipt of external research support. The number of hours per week spent on research/ scholarly activities was found to be an insignificant predictor $(p \geq .1)$ for the number of books or monographs published or edited alone or in collaboration. These findings corroborate results of prevlous studies that found the amount of time faculty spend on research to be an important predictor of high research productivity (Allison \& Stewart, 1974; Harrington, 1985).

Levels of research productivity for faculty who reported current engagement in research were higher in all categories of comparison than research levels for faculty who indicated no current engagement in research. Current engagement in research/scholarly activities was found to be a significant predictor $(p \leq .1)$ for four of the flve measures of research productivity utilized in this study--number of articles published in academic or professional journals, number of articles published in edited collections or volumes, number of books or monographs published or edited alone or in collaboration, and number of professional writings published or accepted for publication in the 
Faculty research productivity 159

past two years. Current engagement in research was not found to be a significant predlctor $(p \geq .1)$ for the receipt of external research support.

Faculty who indicated the receipt of internal research support in the past twelve months reported higher levels of research performance across all categories of comparison than faculty who indicated no receipt of internal research support reported. The need for internal research support in order to be a productive researcher has been documented in previous studies by Creswell (1985, p. 50), Ingalls (1982), and Wood (1990). When regressed with the other seven correlates of faculty research productivity used in this study, internal research support was found to be a significant predictor $(p \leq .1)$ for two of the five measures of faculty research performance--the number of articles published or accepted for publication in the last two years and the recelpt of external research support. Receipt of internal research support was the highest correlate for receipt of external research support. The receipt of internal research support was not found to be a significant predictor $\langle p \geq .1\rangle$ for the number of articles published in academic journals, the 
Faculty research productivity 160

number of articles published in edited collections or volumes, and the number of books or monographs published or edited.

The rank order found between the correlates of faculty research productivity used in this study and the measures of faculty research performance is as follows: 1-the number of articles published in academic or professional journals $(R=.26)$; 2 -the number of professional writings published or accepted for publication in the past two years $(R=.18)$; 3 -the receipt of external research support $(R=.09) ; 4$-the number of articles published in edited collections or volumes $(R=.08)$; and 5 -the number of books or monographs published or edited alone or in collaboration $(R=.06)$.

The descriptive data presented in this study can inform faculty and academic administrators as they develop strategles for faculty research development. For example, referring to the research model, this study underscores the importance of rank (reinforcement) and institutional affiliation (cumulative advantage) on each of the five measures of individual faculty research productivity. Engagement in 
Eaculty research productivity 161

scholarly work (psychological-individual) and the hours spent per week on research and/or scholarly activities (cumulative advantage) were shown to be significantly related $(p \leq .1)$ to four of the $f$ ive measures of research performance.

The results of this study could prove useful to presidents, deans, chairs, and personnel committees who review faculty credentials from different departments and disciplines. The descriptive data provided in this study might serve as one source of information for assessing the level of individual faculty research productivity.

Findings from this study can also be used to inform faculty and academic administrators as they develop guidelines to evaluate faculty research performance. How the individual research productivity of faculty varies by institutional afflilation, rank, discipline, tenure status, gender, the number of hours spent per week on research and or scholarly activities, current engagement in scholarly work, and the receipt of internal research support, is indicated by the interpretation of data presented in this study. The practical implications of these findings indicate the 
Faculty research productivity 162

need to move away from institution-wide evaluation of faculty research performance and to move toward the establishment of ongoing departmental and or disciplinary evaluation procedures.

A synthesis of the literature relevant to faculty research productivity and the limitations of this study raise questions and indicate possible avenues for further scholarly investigation.

1. How do specific correlates of the work environment such as colleagues, socialization processes, participation in campus governance, and reward systems affect faculty research productivity? Researchers might consider holding variables such as institutional affiliation, discipline, and rank constant in order to examine significant correlates of the work environment that would have a positive predictive influence on individual faculty research performance.

2. What is the relationship between faculty career stages and the level of research performance? Researchers could attempt to relate the levels 
Faculty research productivity 163

of individual faculty research productivity to career or developmental stages.

3. What measures of faculty research performance In addition to publication counts, citation counts, and peer or colleague ratings can be used to measure individual faculty research productivity? Researchers should endeavor to expand commonly used measures of faculty research productivity to include alternative measures of research performance such as production of computer software, receipt of patents, and participation in art exhibits, musical recitals, and competitions.

4. What practical application does research on individual faculty research productivity have for academic administrators and faculty? Efforts should continue to translate research findings into viable approaches to faculty development and evaluation.

These research questions represent potential areas of future inquiry relative to individual faculty research productivity. It is evident from these 
Faculty research productivity 164

questions that the relationship between research correlates and measures of research performance must be included in further study to facllitate a better understanding of individual faculty research performance. Because of the importance placed on individual faculty research productivity on college and university campuses, continued efforts to understand correlates that have a positive influence on research performance, to expand commonly used measures of research productivity, to relate the levels of Individual faculty research productivity to career or developmental stages, and to translate research findings into practical approaches to faculty development and evaluation are imperative. 


\section{REFERENCES}

Allison, P. D. (1980). Inequality and scientific productivity. Social Studies of Science, 10, $153-179$.

Allison, P. D. and Stewart, J. A. (1974). Productivity differences among scientists: Evidence for accumulative advantage. American Sociological Review, $39,596-606$.

Alstyne, W. V. (1985). Tenure: A summary, explanation, and "defense." In M. Finkelstein (Ed.) ASHE reader on faculty and faculty issues in colleges and universitles (pp. 165-170). Lexington, Massachusetts: Ginn Press.

Astin, H. S. (1969). The Woman Doctorate in America. New York: The Russell Sage Foundation.

Astin, H. S. (1978). Factors affecting women's' scholarly productivity. In H. S. Astin and W. $Z$. Hirsch (Eds.), In the hloher education of women: Essays in honor of Rosemary Park. New York: Praeger Publishers. 
Astin, H. S. (1984). Academic scholarship and its rewards. In M. Steinkamp and M. Maehr (Eds.), Advances in Motivation and Achlevement, 2 . Greenwich, Connecticut: JAI Press.

Babbie, E. R. (1973). Survey research methods. Belmont, California: Wadsworth Publishing Company, Inc.

Babchuk, N. \& Bates, A. (1962). Professor or producer: The two faces of academic man. Social Forces, 40 , $341-348$.

Baldwin, R. E. \& Blackburn, R. T. (1981). The academic career as a developmental process: Implications for faculty. Journal of Hlaher Education, $52,598-614$.

Baldwin, R. E. \& Blackburn, R. T. (1985). In M. Finkelstein (Ed.), ASHE reader on faculty and faculty issues in colleges and universities (pp. 106-118). Lexington, Massachusetts: Ginn Press.

Bayer, A. E'. \& Dutton, J. E. (1977). Career age and research--Professional activities of academic scientists. Journal of Higher Education, 48 , $259-282$. 
Fáculty research productivity 167

Bayer, A. E. \& Folger, J. (1966). Some correlates of a citation measure of productivity in science. Soclology of Education, 39, 381-390.

Bernard, J. (1964). Academic women. University Park, Pa.: Pennsylvania State University Press.

Biglan, A. (1973). The characteristics of subject matter in different academic areas. Journal of Applled Psychology, 57 (3), 195-203.

Blackburn, R. T., Behymer, C. E. \& Hall, D. E. (1978). Research note: Correlates of faculty publications. Soclology of Education, 51, 132-141.

Blau, P. (1973). The organization of academic work. New York: Willey.

Bowen, H. R. \& Schuster, J. H. (1985). The faculty at risk. In M. Finkelstein (Ed.), ASHE reader on faculty and faculty issues in colleges and universities (pp. 13-18). Lexington, Massachusetts: Ginn Press.

Bowen, H. R. \& Schuster, J. H. (1986). American professors: A national resource imper lled. New York: Oxford University Press. 
Faculty research productivity 168

Braxton, J. M. \& Toombs, W. (1982). Faculty uses of doctoral tralning: Conslderation of a technique for the differentiation of scholarly effort from research activity. Research in Higher Education, 16 (3), 265-282.

Cameron. S. W. \& Blackburn, R. T. (1981). Sponsorship and academic success. Journal of Higher Education. 52, $369-377$.

Caplow, T. \& McGee, R. J. (1958). The academic marketplace. Garden City, New York: Anchor Books.

Carnegie Council on Policy Studies in Higher Education. (1980). Three thousand futures: The next twenty years for higher education. San Francisco: Jossey-Bass.

Carnegie Foundation for the Advancement of Teaching. (1989). The condition of the professoriate: Attitudes and trends, 1989. Princeton, N.J.: Author. 
Faculty research productivity 169

Centra, J. A. (1977). How universities evaluate faculty performance: A survey of department heads. GRE Board Research Report GREB No. 75-5bR. Princeton, N. J: Graduate Record Examinations Program, Educational Testing Service. ED 157445.26 pp.

Chait, R. P. \& Ford A. T. (1985). Tenure in contest. In M. Finkelstein (Ed.), ASHE reader on faculty and faculty issues in colleges and universities (pp. 171-179). Lexington, Massachusetts: Ginn Press.

Chronister, J. L., Baldwin, R. G., \& Bailey, T. G. (1991). Ful1-Time Non-Tenure-Track Faculty: Current Status, Future Prospects, Remaining Research Questions. Paper presented at the annual meeting of the Association for the Study of Higher Education, October, Boston, Massachusetts.

Clemente, F. (1972). Measuring sociological

productivity: A review and a proposal. The American Sociologist, I, 7-8.

Cole, J. R. (1979). Fair science. New York: The Free Press. 
Faculty research productivity 170

Cole, J. R. \& Cole, S. (1973). Social stratification in science. Chicago: The University of Chicago Press.

Cole, J. R. \& Zuckerman, H. (1984). The productivity puzzle: Persistence and change in patterns of publication of men and women scientists. In M. W. Steinkamp and M. L. Maehr (Eds.) Advances in motivation and achievement, $\underline{2}$. Greenwich, Conn.: JAI Press.

Cole, S. (1979). Age and scientiflc performance. Amerlcan Journal of Sociology, 84, 958-977.

Cox, L. M. (1980). Scientific productivity: A critical test of several hypotheses (Doctoral dissertation, Southern Illinois University, 1980). Dissertation Abstracts International, $41,08 \mathrm{~A}$.

Crane, D. M. (1965). Scientists at major and minor universities: A study of productivity and recognition. American Sociological Review, 30 , $699-714$.

Creswell, J. W. (1985), Faculty research performance: Lessons from the sclences and the social sciences. ASHE-ERIC HIgher Education Report No.4. Washington, D.C.: Association for the Study of Higher Education. 
Faculty research productivity 171

Creswel1, J. W. (1985a). Conceptual explanations of research performance. In M. Finkelstein (Ed.) ASHE reader on faculty and faculty issues in colleges and universities (pp. 240-48). Lexington, Massachusetts: Ginn Press.

Creswell, J. W. (1986). Measuring faculty research performance. New Directions for Institutional Research, No. 50. San Francisco: Jossey-Bass.

Creswel1, J. W., Barnes, M. W. \& Wendel, R. (1982). Correlates of Faculty Research Productivity. Paper presented at the annual meeting of the American Educational Research Association, March, New York, New York.

Creswe 11, J. W., Patterson, R. A. \& Barnes, M. W. (1984). Enhancing Faculty Research Productivity. Paper presented at the meeting of the Association for the Study of Higher Education, March, Chicago, Illinois.

(Creswell, J.W. \& Wheeler, D. (1985). Develop Ing Faculty as Researchers. Paper presented at the meeting of the Association for the Study of Higher Education, March, Chicago, Illinois. 
Faculty research productivity 172

F'erber, M. A. \& Loeb, J. W. (1973). Performance, rewards and perceptions of sex discrimination among male and female faculty. American Journal of Soclology, 78 (4), 995-1002.

Ferguson, G. A. \& Takane, Y. (1989), Statistical analysis in psychology and education. New York: McGraw-Hill.

Finkelstein, M. J. (1980). Understanding American Academics: What Have We Learned and Where Do We Go From Here? Department of Higher Education, State University of New York at Buffalo, Occasional Paper Number Six.

Finkelstein, M. J. (1984). The American academic profession. Columbus, Ohio: Ohio State University Press.

$\checkmark$ Finkelstein, M. J. (Ed.). (1985). ASHE reader on faculty and faculty issues in colleges and unlversities. 2nd edition. Lexington, Massachusetts: Ginn Press.

Finkelstein, M. J. (1990). Enhancing faculty careers. San Francisco: Jossey-Bass. 
Faculty research productivity 173

Folger, J. K., Astin, H. S., \& Bayer, A. E. (1970). Human resources and higher education: Staff report of the Commission on Human Resources and Advanced Education. New York: The Russell Sage Foundation.

- Fox, M. F. (1983). Publication productivity among scientists. Social studies of science. $13(2)$, 285-305.

Fulton, 0. \& Trow, M. (1974). Research activity in American higher education. Soclology of Education, 47, $29-73$.

Gaff, J. G. (1976). Toward faculty renewal: Advances in faculty, instructional, and organizational development. San Francisco: Jossey-Bass.

Gaston, J. (1978). The reward system in British and American science. New York: John Wiley \& Sons.

Gibbs, P. \& Locke, B. (1989). Tenure and promotion in accredited graduate social work programs. Journal of Social Work Education, 25 (2), 126-133. 
Faculty research productivity 174

Gi11. J. I. (1991). Interview. In D. Blum (Author), Many studies of future academic job market are sald of be of little use to pollcy makers (pp. A15, A19). Chronicle of Higher Education, February 20.

Gilman, D. C. (1886). The relation of unlversities to the progress of civilization. U.N.Y., Report.

Hargens, L. L. (1985). Disciplinary Differences in Journal Acceptance Rates. Paper presented at the annual meeting of the society for Soclal Studies of Science, October, Troy, New York.

Hargens, L. L., McCann, J. C., \& Reskin, B. F. (1978). Productivity and reproductivity: Fertility and professional achievement among research scientists. Social Forces, 5?, 154-163.

Harrington, M. K. (1985). Environmental, organizational, and faculty characteristics that relate to dental school research productivity cDoctoral dissertation, University of Missouri, 1985). Dissertation Abstracts International, 47, $01 A$. 
Faculty research productivity 175

Hoffman, R. A. (1984). An assessment of the teaching, research, and service function of a college faculty. Journal of Research and Development in Education, $17,49-54$.

Holley, J. W. (1977). Tenure and research productivity. Research in Higher Education, 6 (2), 181-192.

Hopkins, K. D., Glass, G. V. \& Hopkins, B. R. (1987). Basic statistics for the behavioral sciences. Englewood Cliffs, New Jersey: Prentice-Hall.

Horowitz, S. M., Blackburn, R. T. \& Edington, D. W. (1984). Some Correlates of Stress with Health and Work/Life Satisfaction for University Faculty and Administrators. Paper presented at the annual meeting of the Association for the Study of Higher Education, March, Chlcago, Illinois.

Hunter, D. E. \& Kuh, G. D. (1984). A Profile of Prolific Scholars in Higher Education. Paper presented at the annual meeting of the American Educational Research Association, April, New Orleans, Louisiana. 
Faculty research productivity 176

Ingalls, W. B. (1982). Increasing research productivity in small universities: $A$ case study. The Canadian Journal of Higher Education, 12, 59-64.

Kaplan, N. (1964). Sociology of sclence. In R. E. Faris (Ed.), Handbook of modern soclology ( $p p .852-881$ ). Chicago: Rand McNally.

Kearney, R. T. (1987). A model for nurse faculty research productivity (Doctoral dissertation, University of Florida, 1987). Dissertation Abstracts International, $48,08 \mathrm{~B}$.

Kidder, L. H. \& Judd, C. M. (1986). Research methods in social relations. Chicago: Holt, Rinehart and Winston, Inc.

Xim, S. (1990). A study of the advantage of organizational context on academic research productivity: The case of chemistry faculty (Doctoral dissertation, University of Pittsburgh, 1990). Dissertation Abstracts International, 51 , $05 A$.

Kirschling, W. (Ed.). (1978). Evaluating faculty performance and vitality. San Francisco: Jossey-Bass. 
Knorr, K. D.. Mittermeir, R., Alchnolzer, G., \& Waller, G. (1979). Individual publication productivity as a social position effect in academic and industrial research units. In F. M. Andrews (Ed.), Scientific productivity: The effectiveness of research groups in six countries (pp. 55-94). Cambridge: Cambridge University Press.

Kroc, R. J. (1983). Measuring scholarly productivity (Doctoral dissertation, University of Colorado at Boulder, 1983). Dissertation Abstracts International, $44,09 \mathrm{~A}$.

Kuhn, T. S. $(1970)$. The structure of scientific revolutions. Chicago: University of Chicago Press.

Ladd, E. C., Jr. (1979). The work experience of American college professors: Some data and an argument. Current Issues in Higher Education, 2, Washington D.C.: American Association for Higher Education.

Lazarsfeld, P. R. \& Thlelens, W., Jr. (1958). The academic mind. Glencoe, I11.: The Free Press. 
Faculty research productivity 178

Llebert, R. J. (1976). Productivity, favor, and grants among scholars. American Journal of Sociology, 82 (3), 664-673.

Lightfield, E. T. $(1971)$. Output and recognition of sociologists. The American Sociologist, 6, 128-133.

Lindsey, D. (1978). The scientific publication system In social science. San Francisco: Jossey-Bass.

Lodah 1, J. B. \& Gordon, G. (1972). The structure of scientific fields and the functioning of university graduate departments. American Sociological Review, 37. $57-72$.

Long, J. S. (1978). Productivity and academic position in the scientific career. American Sociological Review, 43, 889-908.

Long, J. S. (1990). The origins of sex differences in science. Social Forces, 68 (4), 1297-1316.

Long, J. S. \& McGinnis, R. (1981). Organizational context and scientific productivity. American Sociological Review, 46, 422-442. 
Faculty research productivity 179

McKeachie, W. J. (1969). Perspectives from psychology: Financial incentives are ineffective for faculty. In D. R. Lewis \& W. E. Becker (Eds.), Academic rewards in higher education (pp. $3-20)$. Cambridge, MA: Ballinger.

Manis, J. G. (1951). Some academlc influences upon publication productivity. Social Forces, 29, $269-272$.

Mege 1, M. E., Langston, N. F. \& Creswel1, J. W. (1988). Scholarly productivity: A survey of nursing faculty researchers. Journal of Professional Nursing, 4 , $45-54$.

Meisinger, R. J., Purves, R. A., \& Schmidtlein, F. A. (1975). Productivity from an interorganizational perspective. In R. W. Wallhaus (Ed.) Measuring and Increasing Academic Productivity. New Directions for Institutional Research, Vol. II, No. 4. San Francisco: Jossey-Bass.

Merton, R. (Ed.). (1973). The sociology of sclence: Theoretical and empirical investigations. Chicago: The University of Chicago Press. 
Faculty research productivity 180

Merton, R. K. \& Gaston, J. (1977). The sociology of science in Europe. Carbondale: Southern Illinois University Press.

Neumann, Y. (1979). Research productivity of tenured and nontenured faculty in U.S. Universities: A comparative study of four fields and polley implications. The Journal of Educational Administration, 17, 92-101.

O'Connell, C. (1983). College policies off-target in fostering faculty development. Journal of Higher Education, 54 ( 6 ), 662-675.

Over, R. (1982). Does research productivity decline with age? Higher Education, 11 (5), 511-520.

Pelz, D. C. \& Andrews, F. M. (1966). Scientists in organizations. New York: Wiley.

Perrucci, R., O'Flaherty, K., \& Marshall, H. (1983). Market conditions, productivity, and promotion among university faculty. Research in Higher Education, 19 (4), 431-439. 
Faculty research productivity 181

Persell, C. H. (1983). Gender, rewards and research in education. Psychology of Women Quarterly, 8 (1), $33-47$.

Reskin, B. F. (1977). Scientific productivity and the reward structure of science. American Sociological Review, 42, 491-504.

Reskin, B. F. (1980). Age and scientific productivity: A critical review. In M. McPherson (Ed.), The Demand for New Faculty in Science and Engineering. Proceedings of the Workshop of Specialists in Forecasts of Demand for Scientists and Engineers, 1979. Washington, D.C.: Commission on Human Resources, National Research Council, National Academy of Sciences.

Robbins, S. P., Corcoran, K. J., Hepler, S. E., \& Magner, G. W. (1986). The effect of tenure on scholarly productivity. Arete, 11 (1), 10-16.

Roe, A. (1953). The making of a scientist. New York: Dodd, Mead.

Rosenfeld, R. (1987). Gender, academic mobility, and career success, Social Science, 72, 195-197. 
Faculty research productivity 182

Runyon, R. P. \& Haber, A. (1988). Fundamentals of behavioral statistics. New York: Random House.

Schuster, J.H. \& Wheeler, D. W. (1990). Enhancing faculty careers. San Francisco: Jossey-Bass.

Schweitzer, J. C. (1989). Factors affecting scholarly research among mass communications faculty. Journalism Quarterly, 66 (2), 410-417, 452.

Seldin, P. (1984). Faculty evaluation: Surveying policy and practices. Change, 15, 28-33.

Smith, R. \& Fielder, F. E. (1971). The measurement of scholarly work: A critical review of the literature. Educational Record, 52, 225-232.

Storer, N. (1973). Introduction. In R. Merton (Ed.), The sociology of sclence: Theoretical and empirical Investigations. Chicago: The University of Chicago Press. 
Faculty research productivity 183

Tuckman, H. P. (1985). The academic reward structure in American higher education. In M. Finkelstein (Ed.), ASHE reader on faculty and faculty issues in colleges and universities (pp. 119-37). Lexington, Massachusetts: Ginn Press.

Veysey, L. R. (1965). The emergence of the American University. Chicago: The University of Chicago Press.

Wal Ihaus, R. A. (Ed.). (1975). Measuring and increasing academic productivity. Directions for Institutional Research No. 8. San Francisco: Jossey-Bass.

Wanner, R. A., Lewis, L. S. \& Gregorio, D. I. (1981). Research productivity in academia: A comparative study of the sciences, social sciences, and humanities. Sociology of Education, 54, 238-253.

Wilson, L. (1942). The academic man. New York: Oxford University Press.

Wood, F. (1990). Factors influencing research performance of university academic staff. Higher Education, $19(1), 81-100$. 
Faculty research productivity 184

Worthen, B. R. \& Sanders, J. R. (1987), Educational evaluation: Alternative approaches and practical guidelines. New York: Longman Inc.

Yuker, H. E. (1978). Measuring faculty productivity. In A. Levenstein (Ed.), The uniqueness of collective bargaining in higher education, Proceedings, Sixth Annual Conference. New York: National Center for the Study of Collective Bargaining in Higher Education, City University of New York.

Ziman, J. M. (1968), Public knowledge: An essay concerning the social dimension of science. Cambridge: The University Press.

Zuckerman, H., \& Merton, R. K. (1971). Patterns of evaluation in science: Institutionalization, structure, and functions of the referee system. Minerva. $9,66-100$.

Zuckerman, H. \& Merton, R. K. (1973). Age, aging and age structure in science. In R. K. Merton (Ed.), Sociology of Science (pp. 497-559). Chicago: University of Chicago Press. 
APPENDIX A

Cover Letter and Survey 
Qf the CarNeGIE foundation

FOR THE ADVANCEMENT OF TEACHINC

February 17, 1989

Dear Professor:

Iast week I wrote to you asking for your assistance in our natfonwide survey of college and unlversity faculty. Your cooperation will be enormously helphul to us and vill contribute to our longltudinal study of the Americar professoriate. As Jou mas recall, our study goal is twofold: to learn more about this nation's system of higher education in general as well as the opinjons of faculty members from coast to cosst.

When completing the questionnaire, please be candid. I can assure you that your responses will be held in complete confidence. You need not sisn your name and we do not intend to report responses to or by individual colleges or universities. The bibliographlo questions located at the end of the questionnaire will serve only to improve our anslysis of the survey data.

Please take a few minutes and complete the ourvey and return it in the enclosed prepadd envelope addressed to The Wirthin Group. They are assisting us with the adninistration of this survey. If you wish, also include a self-addressed and stamped envelope for a free summary report of our more interesting findings.

We look forward to receiving your completed questionnaire, and we would appreciate receiving it on or before the end of March in order for your opinions to be included in our national study. Thank you very much for your help.

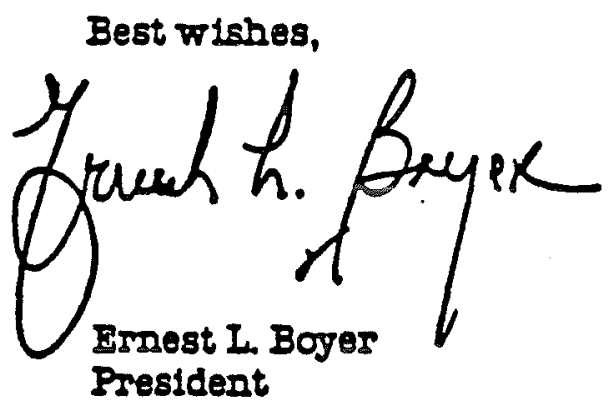

\section{WSTRUCTIONS FOR COMPLETING THE OUESTIONNAARE}

Please read each question carelully. Most questions require only one response, others request that you circle all that apply, while on some you write in a number. A "no opinion" or "neutral" response category is usually provided.

Several questions use a five-point rating scale. You may circle any single number on the scale.

7 you teach at more than one institution, please answer the questions in relation to the college or university where you spend most of your time. 
The following quastlons rofer to your eurment encedemic poatiton.

1. Do you have a full-time appointment at this insttution for at bast nine months of the current academic year?

$$
\begin{aligned}
& 1 \text { Nos } \\
& 3 \text { No, fult-time but tor lase than nine months } \\
& 3 \text {, pame }
\end{aligned}
$$

2. What kind of appointment do you have? (ff you have a poimt appointmant, answer for your primary department)
1 Campus faculty momber, with tenuro
2 Campus taculty member, without tenure
3 Adjund
4 Visiting
5 Other:

2. What is your current academic rank?
1 Lecturor
2 Instructor
3 Assistant Protessor
4 Ascociate Protessor
5 Protessor
6 No rank designated
7 Othar:

4. II you have tenure, please skip to Question 5.

b your eppointment...

1 Untenurad, but on a tenure-track

2 Untenured, with a continuous contract or its equivalent

3 Untemured, not on a tenure track and without the ouarantee of a continuous contract

4 Untenured, but none of the above

5. Al how many colleges of universities have you been amployed full-time as a faculty member beyond the lovel of a teacting assistant? (Indude your current position)

6. For how many eademic years have you been employed on a tull-time basis: (Include current year)
(a) in higher education
(b) at your institution
(c) in your prosent academic rank

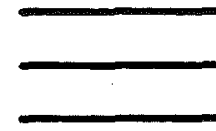

7. Are your teaching responsibilities this soring term...

(Plase circle one response)

1 Entirely undergraduate

2 Sorme undergraduate, some graduale of professional

3 Entirely graduate or protessional

4 Not toeching this spring term-SKIP TO QUESTION 9
8. On everage, about how many students enroll in the typica class you are toaching at each lovel this spring term?

1 Typical introductory undergraduate class

2. Typical advanced undergraduate chass

3 Typical graduate or protessional cless

9. During this Spring ferm, approximately how many hours per woek ars you spending on each of the following ectivities?

2. Formal classroom instruction in undergraduate courses (give sctual, nox crodit hours)

b. Formal ciassroom instruction in graduate or protessional courses (give actual, not credit hours)

c. Preparation tor teaching

d. Research and/or comparable scholarty activities

-. Scheduled office hours

l Administrative service (departmental or institutional)

o. Consulting (with or without pay)

h. Academic actvising

I. Service with cocurricular student ectivitios

1. Supervising graduate teaching essistants

10. Please contrast your teaching load this year with your toaching load five years aco.
1 Much lighter
2 Lohter
3 About the same

4 Heavier

5 Much heavier

6. I was not teaching five years ago

11. From the following list, circle the department of your teaching appointment. Where your discipline does not appear, circte the most similar discipline.

1 Agricutture/Forestry/Natural Resources

2 Allied Health (Medical Technologies)

3 Arctitecture/Environmental Design

4 ArearEIhnic Studies

5 Biological/Life Sciences

6 BusineserManagement

7 Communications/Joumalism

8 Computer/information Science

- Economica

10 Education (including Administration and Counseling)

11 Enginooring

12 Fina Arts (Art, Drama, Music)

13 Foreign Languages

14 Geography

15 Health Prolessions (Dentistry, Modicine, Nursing. Votorinary)

(continued 
11. Cortimed...

16 Home Economics

17 Humanities (Literature, History, Phibsophy, Religion, Theology. Phetoric)

18 industrial Âts

19 Lnw

20 Lbrany Science

21 Mathematics/Statistics

22 Military Science/Technologies

23 Physical and Heath Education

24 Ptysical Sciences

25 Psychology

26 Public Aftairs

27 Social Sciences (Anthropology, Political Science, Sociology, Social Work)

28 VocationalfTechnical Training

29 Other Discipline

We would ithe to learn about your scholarly setivitles. planse answer each of the following.

12. Do your interests lie primarily in research or in teaching?

1 Primarily in research

2 in both, but leaning toward research

3 In both, but leaning toward teaching

4 Primarity in teaching

13. Are you currently engaged in any scholarly work that you expect to lead to a publication, an exhibit, or a musical rectal?

1 Yos

2 No

14. During the east 12 months, did you (or your project) receive research support trom: (Please circle one number br each response)
a. Instrutional or deparimental tunds $\frac{\text { Yes }}{1} \frac{\text { No }}{2}$
b. Federal agencies $1 \cdot 2$
C. State or boal govemment agencies 12
d. Private toundations 12
8. Private industry 12
1 Oher.

15. Approximately how many articies have you ever published in academic or professional journals?

16. Approximately how many articles have you ever published in edited collections or volumes?

7. Approximately how many books or monographs have you ever published or edited, alone or in collaboration?
18. Approximately how many of your professional writings have been publistred or accepled for publication in the PAST TWO YEARS?

19. During the past two vears, have you served as a paid of unpaid consuttant to... (Please cirele one number for each rosponse)

\begin{tabular}{|c|c|c|}
\hline 2 & 3 & A non-proït agency \\
\hline 2 & 3 & A university beneed research project \\
\hline 2 & 3 & Foderal govemment \\
\hline 2 & 3 & A toreign govemment \\
\hline 2 & 3 & A private business or industry \\
\hline 2. & 3 & Schools (elementary or secondary) \\
\hline 2 & 3 & State or beal govemment agencies \\
\hline 2 & 3 & Other: - \\
\hline
\end{tabular}

20. During the past year, how many of the following professional meetings did you attend?

\begin{tabular}{lccc} 
& \multicolumn{2}{l}{ Attended Meetings } & Number Attended \\
\cline { 2 - 4 } \cline { 2 - 3 } National & $\frac{\text { Yos }}{1}$ & $\frac{\text { No }}{2}$ & \\
Regional & 1 & 2 & \\
State & 1 & 2 & \\
Local & 1 & 2 &
\end{tabular}

21. During the past year, have you had any professional contact with teachers in elementary or secondary schools?

1 Yos

2 No

22. Please indicate the extent of youp agreement or disagreement with each of the following statements. A "neutral" response is provided.

1 Strongly agree

2 Agree with reservations 3 Neutral

4 Disagree with reservations

5 Strongly disagree

12345 The goal of an academic scholar is to advance knowledge without regard for the possible implications tor sociaty

12345

Pertorming sponsored research for a private company is not a proper university activity

12345

Scientific progress these days is more $\alpha$ a threat than a positive contribution to human welfare

(continued) 
32. Comtinued...

Pleaso indicate the extent of your agreement or - disagreement with each of the following stalements.

A "neutral" response is provided.

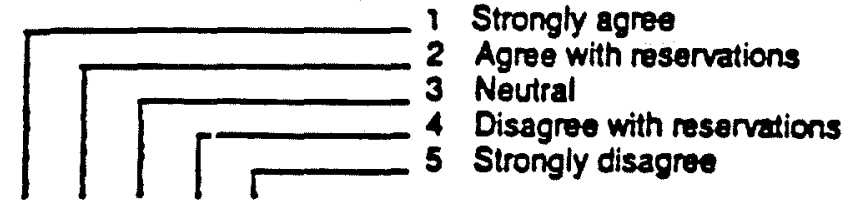
12345
Faculty members should be troe to present in class any idea that they consider rolevant, however much I may disagree with their views
12345
I am apprehensive about the tuture of this country
12345
My discipline is too research oriented
12345
Exciting developments are now
12345 taking place in my discipline
The new developments in my discipline are not interesting to me
12345
In my discipline, most faculty agree on the standards of good scholarship
12345
During the past two or three years financial support for work in my discipline has become harder to obtain
82345
Faculty members in high sctools and colleges should work together to improve education in my discipline

Tenure h one of many concerns voiced by faculty members. Your response to this set of questions will holp us to better understand this important issue.

23. Please indicate the extent of your agreement or disagreement with each of the following statements. A "neutral" response is provided.

1 Strongly agree

2 Agree with reservations

3 Neutral

4 Disagree with reservations

${ }^{\square}{ }^{4}$ Strongly disagree

12345 in my department tenure is now more difficult to achieve than it was five years ago

12345

Many young faculty members at this institution will leave because it is "tenured in"

12345

The abolition of faculty tenure would, on the whole, improve the quality of American higher education

(continued)

23. Continued...

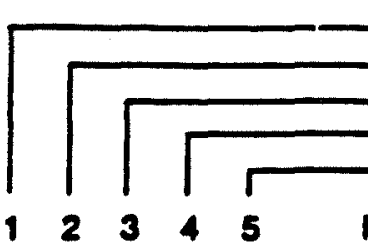

1 Strongly agree

2 Agree with reservations

3 Neutral

4 Disagree with reservations

5 Strongly disagree

12345

In my department it is difficutt for a person to achieve tenure if the or she does not publish

12345 At my institution publications used for tenure and promotion are just "counted", not qualitatively measured

12345

At my institution need better ways, besides publications, to ovaluate the scholarty performance of the laculty

12345

The pressure to publish reduces the quality of teaching a my universty

12345 Teaching effectiveness should be the primary criterion for promotion of faculty

12345 Al my campus, scademic freedom would be protected whether faculty members could get tenure or not

12345

Multidisciplinary work is "solt" and should not be considered scholarship

24. How important are the following for granting tenure in your depariment?

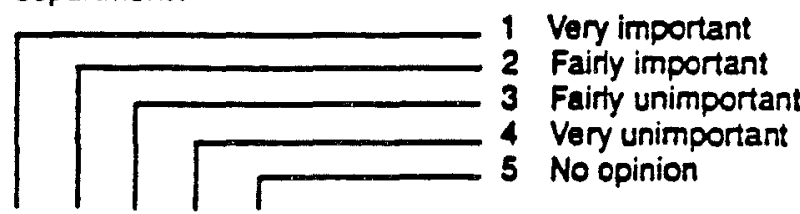

12345

12345

$12 \cdot 345$

12345

$\begin{array}{lllll}1 & 2 & 3 & 4 & 5\end{array}$

$\begin{array}{lllll}1 & 2 & 3 & 4 & 5\end{array}$

12345

12345

12345
The number of publications

The type of publications (books. odited volumes, articles)

The reputations of the presses or joumals publishing the books or articles

Published reviews of the scholarts books

Research grants received by the scholar

Syllabi tor courses taught

Recommendations from current or former students

Observations of teaching by colleagues andior administrators

Lectures or papers delivered at prolessional melings or at other colleges and universities 
24. Continued...

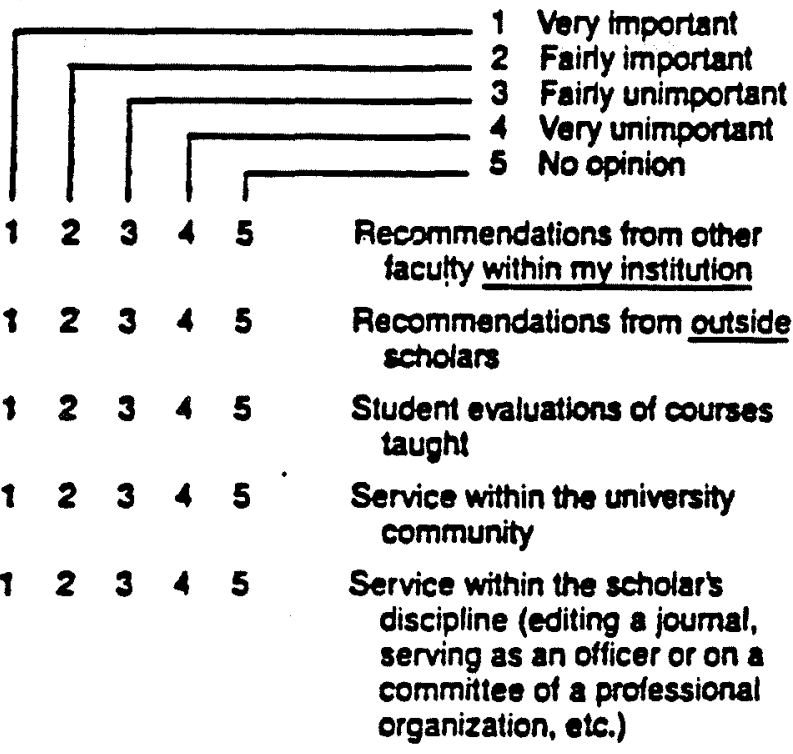

12345 Academic advisement

The following questions refer to the instfiution at which you are currently employed. Please tell us your candld opinions.

25. In general, how do you feel about your institution? it is...

1 A very good place tor me

2 A tairly good place for me

3 Not the place for me

26. Please rate the pertormance of vour institution for each of the following activities. (Please circle the number that best describes your assessment)

\section{Excellent}

Somewhat better than adequate

Adequate

Somewhat less than adequate

Poor

Providing undergraduates with a general education
12345
Preparing undergraduates for a vocation or careep
12345
Providing undergraduates the opportunity to explore personal interests through electives
12345
Providing opportunities for an undergraduate to explore a subject in depth, through the major
12345 Strengthening the values of undergraduates
12345
Creating opportunities for undergraduates to engage in public service
12345

27. Who has primary responsibility for the academic advising at your institution?
1 Faculty
2 Full-time actvisors
3 Student atfairs protessionals
4 Others:
5 No formal provision

28. In general, for each of these areas, the academic standards at my institution should be... (Please circle one number for each response)

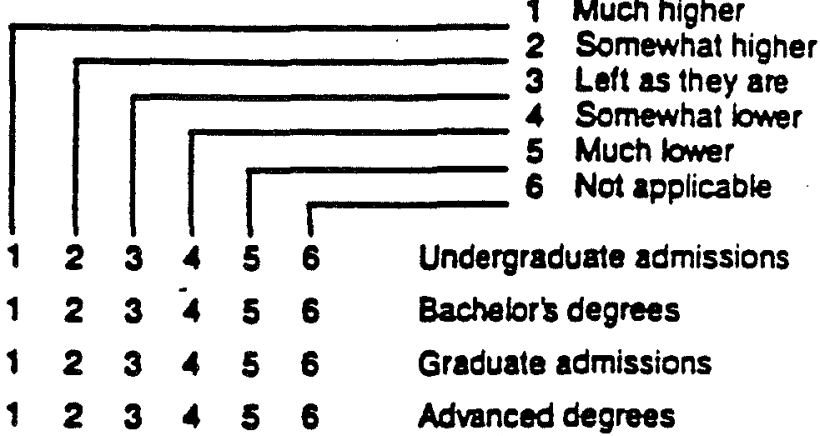

29. In general, for each of these areas, the academic standards in my department should be... (Please circle one number for each response)

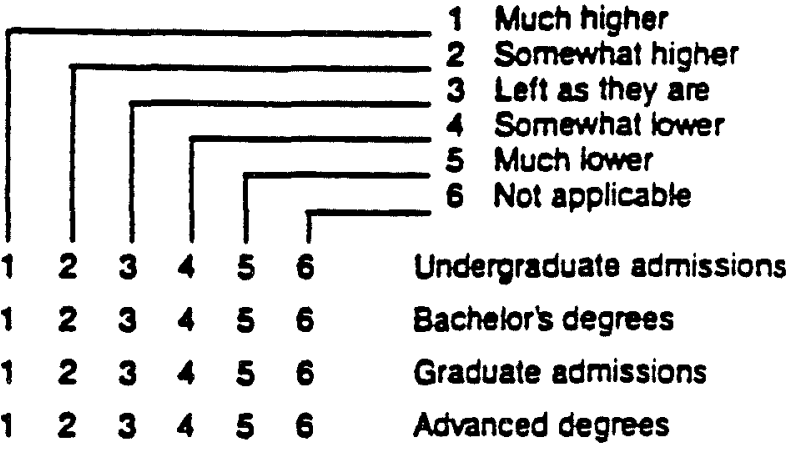

30. Please indicate the extent of your agrieement or disagreement with each of the following statements. A "neutral" response is provided.

\section{Strongly agree}

2 Agree with reservations

3 Neutral

4 Disagree with reservations

5 Strongly disagree

My institution is managed effectively
12345 The administration here supports academic freedom

12345

Faculty members who become administrators soon lose sight of what it means to be a teacher or to do research

12345
A small group of senior protessors has disproportionate power in the decision-making at my institution 
30. Continued...

Please indicate the extent of your agreement or disagreement with each of the following statements. A treutral" response is provided.

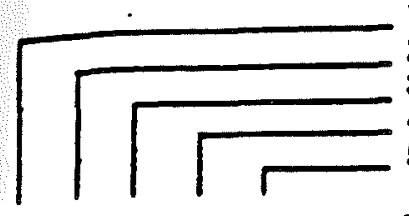

12345

12345

12345

2345

12345

2345

12345

2345

2 Agree with reservations

3 Noutral

4 Disagree with reservations

5 Strongly disagreo

This institution spends too much time and money teaching students what they should have leamed in high school

This institution has serious financial problems

In the next five years, 1 expect that some of the tenured faculty here will lose their jobs due to lack of funds

There are more part-lime and adjunct faculty members at this institution today than there were five years ago

My institution is as interested now in increasing the numbers of women and minority members on our faculty as it was five years ago

I am satisfied with the results of affirmative action at this institution

Issues raised by atfirmative action are causing serious strains among the lacutty in my degartment

The normal academic requirements should be relaxed in appointing members of minority groups to the faculty at this institution

12345

12345

12345

12345

Junior faculty members have too little say in the running of $m y$ department

Faculty in my department have fundamental differences about the nature of the discipline

Faculty meetings in my department generally are a waste of my time

My department has had to live with more than its fair share of budget restraints over the past several yoars

12345
There is more alcohol abuse among my colleagues than there was five years ago
The following questions concern college curriculum in general and the curriculum at your Institution. Please tell us your opinions by answering each question.

31. Apart from major field requirements, should undergraduates at your institution be required to take... (Circle one)

1 A required common core curriculum

2 Breadth requirements in general education

3 No required courses, only elective courses

4 A public service intemship

5 I have no opinion

32. Many goals have been proposed for undergraduate education. Please indicate the importance of each of the bllowing goals. To...

1 Very important

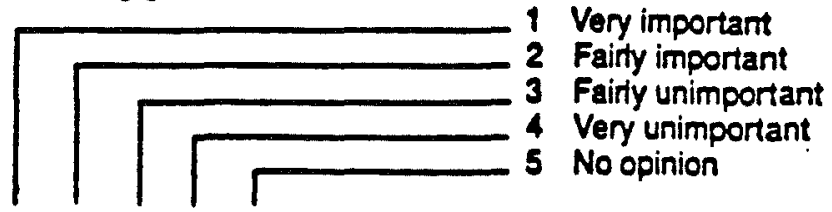

12345 Provide an appreciation of Herature and the arts

$\begin{array}{llllll} & 2 & 3 & 5 & \text { Shape students' values }\end{array}$

$\begin{array}{llllll}1 & 2 & 3 & 5 & \text { Enhance creative thinking }\end{array}$

12345

Provide a basic understanding in mathematics and science

12345

Provide knowledge of history and the social sciences

$\begin{array}{llllll}1 & 2 & 3 & 4 & 5 & \text { Prepare students for a career }\end{array}$

$\begin{array}{llllll}1 & 34 & 4 & \text { Provide knowledge of one }\end{array}$ subject in depth

33. How would you evaluate the undergraduate curriculum at your institution? (Please circle the number that best describes your assessment of each)

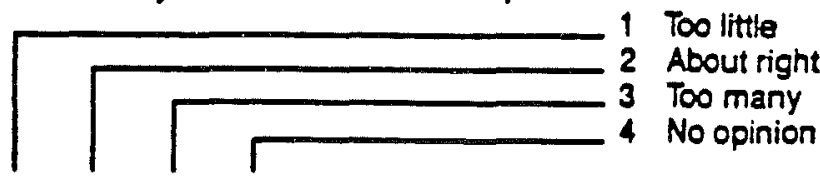

12345 General education requirements

$\begin{array}{llllll}1 & 2 & 3 & 4 & 5 & \text { Requirements for the major }\end{array}$

12345 Requirements for a proprofessional program
12345
Electives in the major
12345
Electives outside the major

34. Please indicate the extent of your agreement or disagreement with each of the following statements. A "neutral" response is provided.

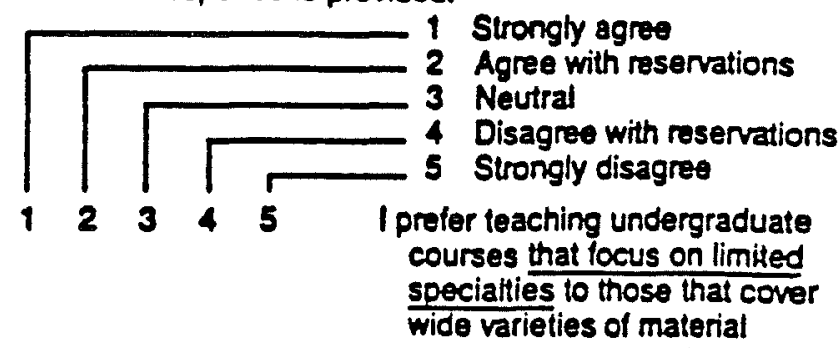

(continued) 
34. Continued...

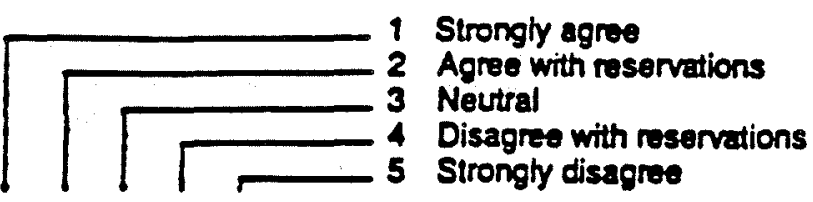

12345 in my undergraduate courses, I prefer teaching students who have a clear idea of the career they will be following

12345 Undergraduate education in America would be improved if there were less emphasis on specialized training and more on broad liberal edueation

12345 The typical undergraduate curriculum has sutfered trom the specialization of facutty members

12345

Undergraduates at my institution are not getting as good an education today as they did five years ago

12345

Outcome assessment of undergraduates using multipte. choice instruments will increase the quality of undergraduate education

12345

State mandated assessment requirements threaten the quality of undergraduate education and intrude on instilutional autonomy

The following questions solicli your assessment of undergraduate students attending your institution. Please inswer each trem.

35. There has been considerable discussion about the change in student orientations from the late 1960 s or early 1970 s to the present. How do you assess each of the following? A "neutral" response is provided.

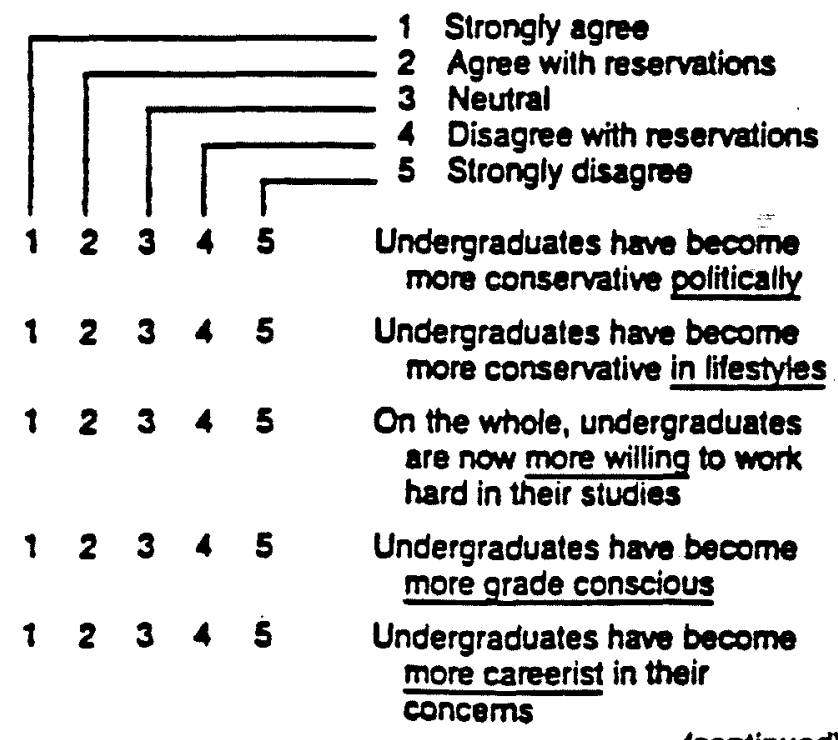

35. Continued...

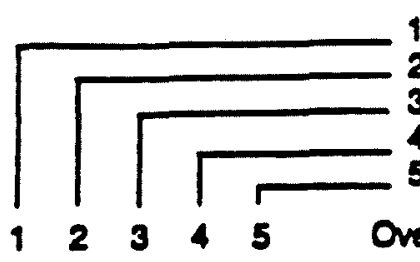

1 Stronghy agree

2 Agree with reservations

3 Neutral

4 Disagree with reservations

Strongly disagree

12345

Overall, the mood of todays undergraduates is better suited to a successful educational experience than was the mood of their counterparts in the late 1960 s or varty 1970 s
12345
12345
12345
12345
12345
12345
12345
12345

Undergraduates today are more competitive acadernically

Today's undergraduates are more willing to cheat in order to get good grades

There is more racism among todays undergraduates than in the late 1960s and earty 1970 s

There is a growing trend among undergraduates to isolate themsehves in small groups

Fratemities and sororities are a more negative force on my campus than they used to be

There is more violence and crime perpetrated by off-campus criminals now

There is more alcohol abuse among today's undergraduates than five years ago

There is more drug abuse among today's undergraduates than five vears ago

36. Please indicate the extent of your agreement or disagreement with each of the following statements. A "neutral" response is provided.

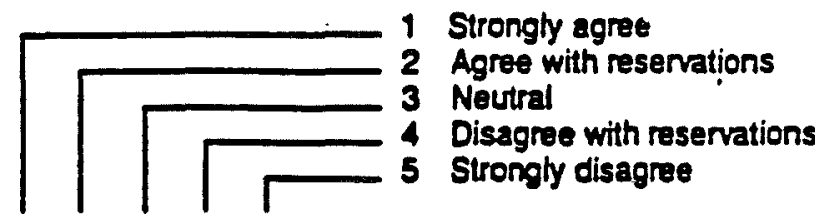

12345 The number of general education (core) courses required of all undergraduates should be increased
12345
I enjoy interacting informally with undergraduates outside the classroom
12345
12345
Most undergraduates expect too much attention
Undergraduates should seek out faculty only during posted office hours

continued 
35. Comtinued...

Please indicate the extent of your agreement of disagreement with each of the following statements. A "neutral" response is provided.

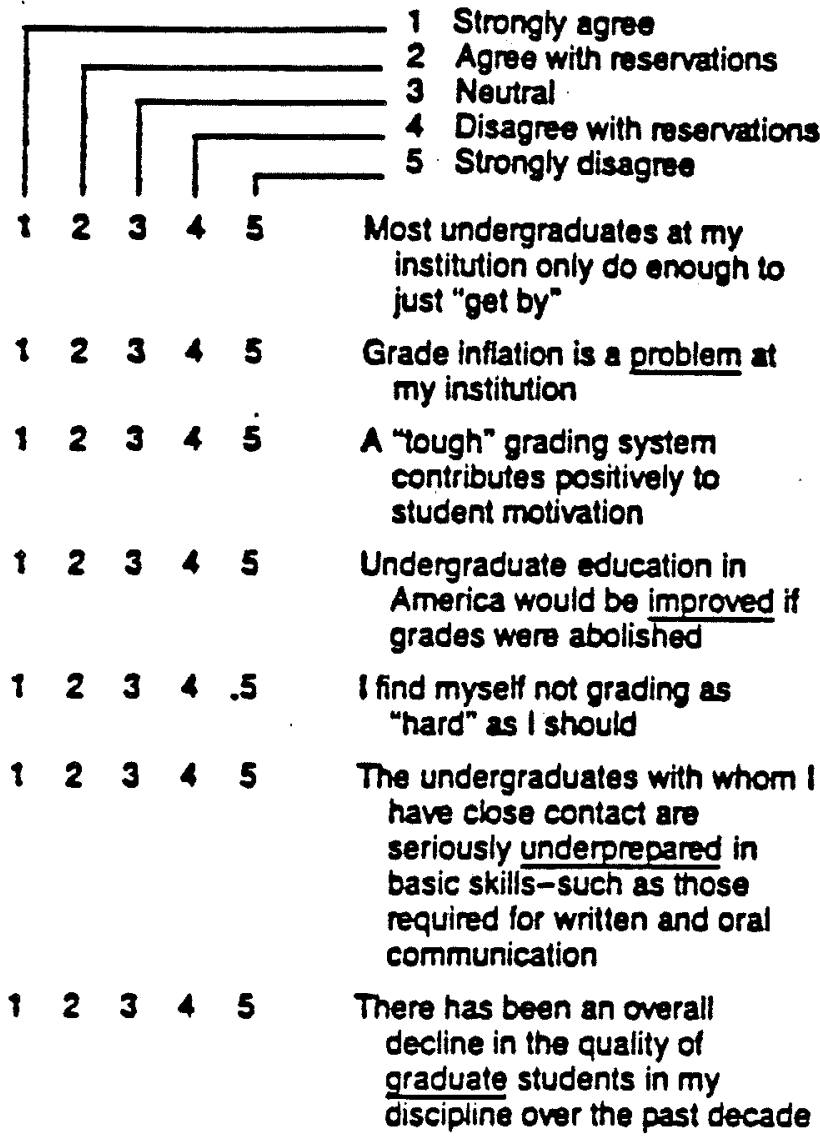

Few topics involving higher education in the United States are receiving more attention than the matter of faculty morale and commitment. Please consider each of the following questions and give us your opinion.

37. Please indicate the degree to which each of the following is important to you.

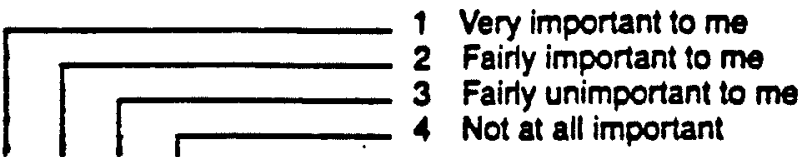
1234
My academic discipline
1234
My department
1234
My college or university
1234
Mj relationship with undergraduates
1234
National or intemational societies in my discipline

38. How much opportunity do you have to influence the policies of: (a) your department; (b) your institution?

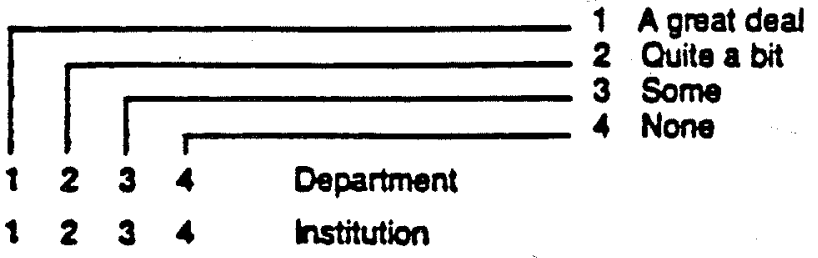

39. Please indicate the extent to which you participate in meetings of each of the following types of organizations at your institution. (Please circle one number for each response)

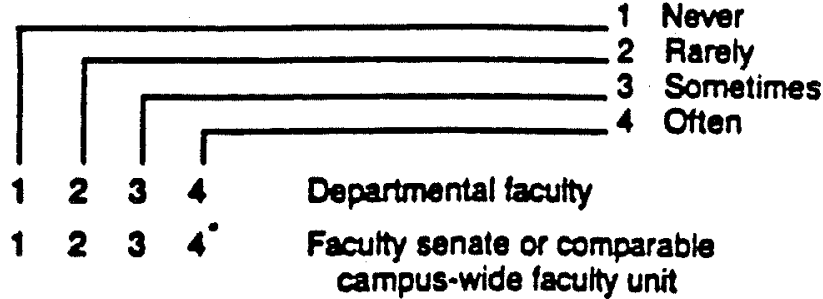
123
Campus-wide laculty committeo
1234
Administrative advisory committee
1234
Academic budget committees

40. How would you rate each of the following?

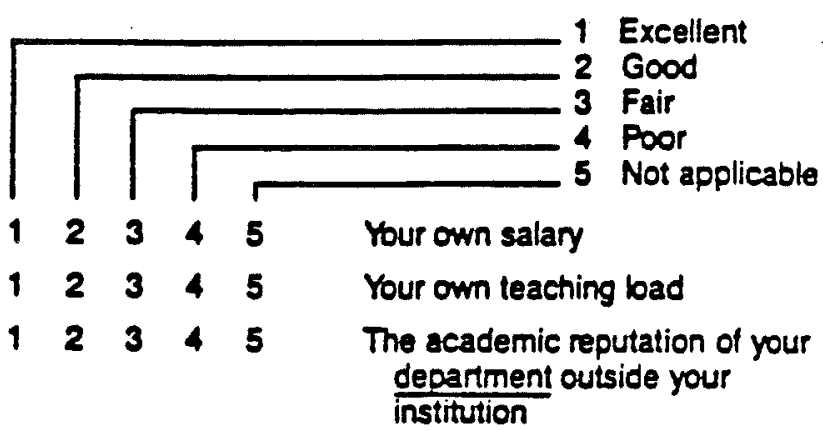
12345
12345
12345
12345
$\begin{array}{lllll}1 & 2 & 3 & 4 & 5\end{array}$

The academic reputation of your institution within your diseipline

The intellectual environment at your institution

Faculty salary levels at your institution

The administration at your institution
12345
The quality of life at your instizution

The sense of community at your institution

41. Do you feel that the administration of (a) your institution, (b) your department is...

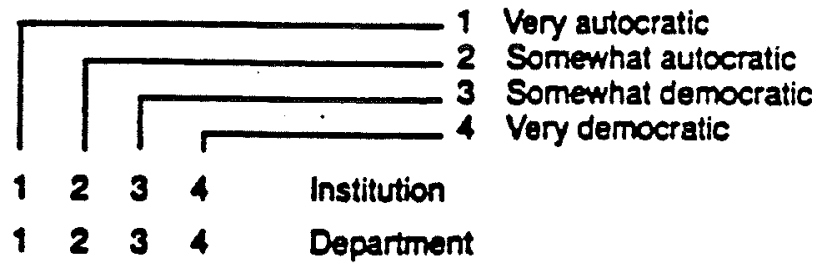

42. How have the following changed over the past five years?

1 Was not teaching fivo years ago

2 Much belter

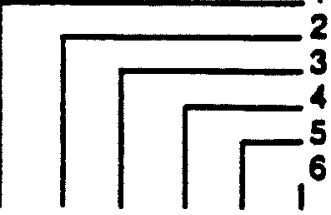

Somewhat better

About the same

Somewhat worse

Much worse

123456

Departinental morale

(continue 
Faculty research productivity 194

42. Continued...

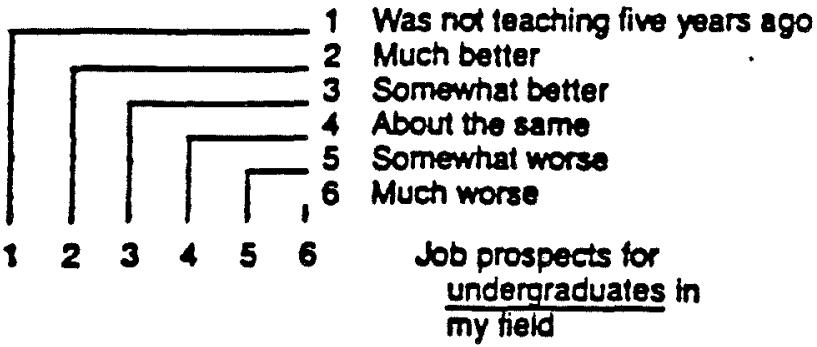
$\begin{array}{lllllll} & 2 & 3 & 4 & 5 & 6 & \text { Job prospects for graduate }\end{array}$ students in my fiald

13. During the past two years, have you over considered a permanent depañure from academia?
1 Yes, I have given it serious consideration
2 Yes, I have considered it, but nat seriously
3 No

44. How Fikety are the following changes in your career?

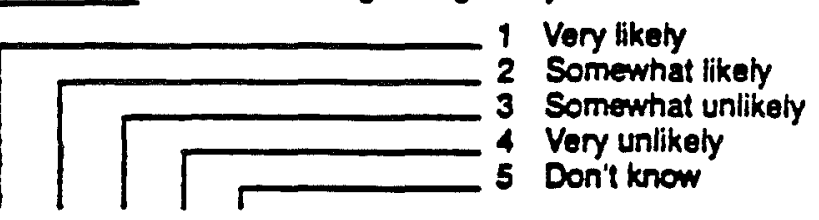
12345
That you will seek a research position outside academia during the next five years?
12345 That you will seek an administrative position outside academia during the next five years?
12345 That your academic position would be in jeopardy if there were tacutty eutbacks during the next five years?

45. Please indicate your agreement or disagreement with each $\alpha$ these statements. A "neutral" response is provided.

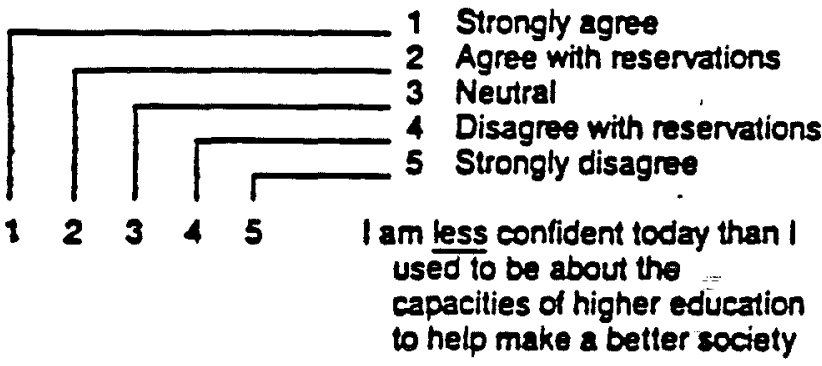
12345 Too many students ill-suited to academic life are now enrolling in colleges and universities

12345 The United States is creating an over-trained work force in terms of available jobs

12345 There has been a widespread lowering of standards in American higher education

(continued)
45. Continued...

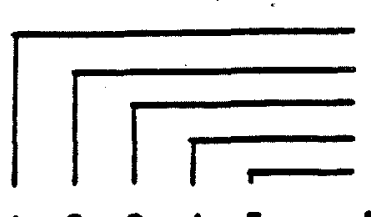

$\begin{array}{lllll}12 & 345 \\ 1 & 2 & 345 \\ 1 & 2 & 345\end{array}$

I Strongly agrea

2 Agree with reservations

3 Neutral

4 Disagree with reservations

5 Strongly disagree

My iob is the source of considerable personal strain

I lend to subordinate all aspects of my life to my work

I hardly ever get time to give a . piece of work the attention it deserves

12345

Members of the academic profession have a responsibility to set a good othical example for their students

12345

Fenwer teutty members provide positive role models to our undergraduates than in the past

12345

This is a poor time tor any younc person to begin an academic career

12345

On the whole, faculty salaries here have keof up with the ratt of inflation

1234.5

II I had it to do over again. I would not become a college teacher

$$
12345
$$

I am considering entering another line of work because prospects for academic advancement seem limited

12345

1 may leave this protession within the next five years

12345 loften wish I had entered anothef prolession

12345

I teel trapped in a profession witt limited opportunities tor advancement

$\begin{array}{lllll}1 & 2 & 3 & 4 & 5\end{array}$

I am more enthusiastic about my work now than I was when I began my academic career

Please answer the following questlons to give us your candid assessment of your retirement plans.

46. At what age is it most likely that you will retire trom full-time academic employment. 
17. What soures of retirement income aro you currently planning on? (Please circle all that apply)

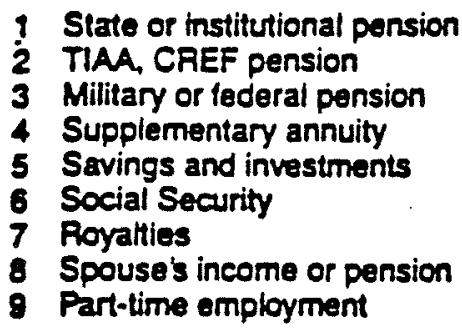

48. Plase indicate your agreement or disagreement with the following statements about retirement. A "neutral" nesponse is provided.

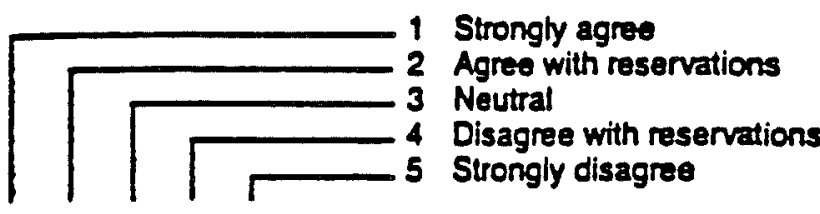
12345 i would exercise an earty retirement option it it wers offered to me
12345 I look forward to retirement as an enjoyable period of my life
12345 I believe that boredom will be a problem tor $m e$ in $m y$ retirement

12345

$l$ intend to engage in research and professional writing during my retirement

I 2345 At my institution, the major puroose of earty retirement programs is to force out less productive faculty

12.345 My institution provides the conditions and support for faculty to retire with dignity

This last section inctudes questions that will be used for classification purposes of the survey data. Your response to exch item is very important and will in no way be bentilied with you, your department, or your sehool.

49. Are you a U.S. citizen?

$\begin{array}{ll}1 & \text { Yes } \\ 2 & \text { No }\end{array}$

50. What is your year of birth? 19

51. How mouid you characterize yourself politically at the present time?

1 Liberal

2 Moderately fiberal

3 Middle-of-the-road

4 Moderately conservativo

5 Conservative
52. On the following list, please indicate the degrees which you currently hold. (Circle all that apply)

1 Less than Bachelor's (A.A., etc.)

2 Bacholor's

3 Master's

4 Ph.D.

5 Ed.D.

610.

7 Other first professional

8 Medical degree (M.D., D.D.S., otc.)

53. Your gender.
1 Malo
2 Formais

54. Your race or ethnic group:

1 Asian

2 Black/Negro/Afro-American

3 Hispanic (non-Black)

4 Native AmericanAmerican Indian

5 White/Cacasian

6 Other

55. From which of the following sources do you receive income to supolement your institutional salary? (Circie all that apply)

1 I have no supplemental source of income

2 Non-ecademic job in the summer

3 Non-academic job evenings or weekends

4 Part-time teaching or research at one or more institutions other than this one

5 Consulting

6 Other protessional activity:

56. In 1988, roughty how much did you eam over and above your institutional salary?

(Please estimate as a percentage of your basic salary)

$\begin{array}{ll}1 & 0 \% \\ 2 & \text { Under } 10 \% \\ 3 & 10 \%-19 \% \\ 4 & 20 \%-29 \%\end{array}$

$530 \%-39 \%$

$640 \%-49 \%$

$750 \%$ and over

$420 \%-29 \%$

57. What is your institutional salary on a full-time basis betore tax and deductions for the current academic year?

1 Below $\$ 16,000$

$2 \$ 16,000-\$ 17,999$

$3 \$ 18,000-\$ 19,999$

$4 \$ 20,000-221,999$

$522,000-\$ 24,999$

$625,000-27,999$

$7528,000-30,999$

$8 \times 31,000-133,999$

$9 \quad \$ 34,000-36,999$

$10 \quad 37,000-39,999$

$11540,000-54,999$

$12 \quad 45,000-49,999$

$13 \quad 550,000-554,999$

$14 \$ 55,000-559,999$

$15580,000<54,999$

$16 \$ 65,000-569,999$

$17 \$ 70,000$ or more 
58. Is this based on...

$$
\begin{aligned}
& 1 \text { 9-10 months } \\
& 2 \text { 11-12 months }
\end{aligned}
$$

\begin{tabular}{|c|}
\hline $\begin{array}{l}\text { No spouse } \\
\text { so } \\
\text { Below \$ } 2,000 \\
\$ 2,000-\$ 3,999 \\
\$ 4,000-\$ 5,999 \\
\$ 6,000-\$ 7,999 \\
\$ 8,000-\$ 9,999 \\
\$ 10,000-\$ 14,999 \\
\$ 15,000-\$ 19,999 \\
\$ 20,000-\$ 24,999 \\
\$ 25,000-\$ 29,999 \\
\$ 30,000-\$ 34,999 \\
\$ 35,000-\$ 39,999 \\
\$ 40,000-\$ 44,999\end{array}$ \\
\hline
\end{tabular}

59. What was your spouse's total eamed income in 1988 ?

\section{EXPLANATION OF THE CARNEGIE} ULASSIFICATION CODE

Shown below is the manner by which the Camegie Foundation roups American colleges and universities on the basis of heir missions and edueational functions. The aim is to group hstitutions according to their shared characteristics, pather han to make qualitative distinctions.

The code tor your sctool is printed on the top of the back page. fleulty and institutions were randonty selected within each amegie classification category.

Research Universities ..........................1 or 2 Doctorate-Granting Universities ......................3 or 4 Comprehensive Universities and Colleges .........5 or 6 Liberal Arts Colleges .............................7 or 8 Two-Year institutions ..............................
Is there anything else you would like to tell us? Please add any thoughts you foel would be heiptul. 
APPENDIX B

Demographic Summary Tables 
Faculty research productivity 198

General Demographic Sumnary of Study Group

Research I Institutions

\begin{tabular}{|c|c|c|c|c|c|c|c|c|}
\hline Variable & Number & Males & Females & $\mathrm{Pr}$ & AoP A & $A_{s} \mathrm{P}$ & & T NT \\
\hline Totals & 562 & 440 & 119 & & 166 & 112 & & \\
\hline Agricul/Forest/Wat Res & 24 & 22 & 2 & 15 & 5 & 4 & & \\
\hline Allied Health & 3 & 1 & 2 & 1 & 2 & 0 & & 2 \\
\hline Archit/Environ Design & 13 & 12 & 1 & 2 & 9 & 1 & & 11 \\
\hline Area/Ethnic Studies & 3 & 3 & 0 & & 0 & 1 & & \\
\hline Biological/Life Sci & 36 & 29 & 7 & 18 & 12 & 5 & & 29 \\
\hline Business/Management & 25 & 22 & 3 & 10 & 8 & 6 & & 17 \\
\hline Communi cations/Jour & 16 & 10 & 6 & 6 & 4 & 6 & & \\
\hline Computer/Infor Sci & 13 & 10 & 3 & 3 & 3 & 7 & & \\
\hline Economics & 11 & 10 & 1 & 6 & 2 & 3 & & 9 \\
\hline Education & 31 & 24 & $?$ & 17 & 10 & 3 & & 25 \\
\hline Engineering & 51 & 47 & 3 & 27 & 11 & 12 & & \\
\hline Fine Arts & 31 & 17 & 14 & 13 & 11 & 7 & & 24 \\
\hline Foreign Languages & 31 & 22 & 8 & 19 & 9 & 3 & & 28 \\
\hline Geography & $?$ & 5 & 2 & 4 & 1 & 2 & & 5 \\
\hline Health Professions & 23 & 6 & 17 & 4 & 10 & 8 & & 13 \\
\hline Home Economics & 6 & 2 & 4 & 0 & 5 & 1 & & \\
\hline Humanities & 73 & 59 & 14 & 36 & 171 & 16 & & 55 \\
\hline Industrial Arts & 0 & 0 & 0 & 0 & 0 & 0 & & \\
\hline Law & 1 & 0 & 1 & 0 & 1 & 0 & & \\
\hline Science & 2 & 2 & 0 & 1 & 0 & 1 & & \\
\hline Math/Statistics & 26 & 24 & 2 & 13 & 9 & 4 & & 21 \\
\hline Military Sci/Tec & 0 & 0 & 0 & 0 & 0 & 0 & & 0 \\
\hline Physical/Heal th Ed & 5 & 3 & 2 & 3 & 0 & 1 & & 5 \\
\hline Physical Sciences & 49 & 48 & 1 & 35 & 11 & 3 & & 45 \\
\hline Psychology & 25 & 17 & 8 & 9 & & 5 & & 17 \\
\hline Public Affairs & 5 & 4 & 1 & 3 & 2 & 0 & & \\
\hline Sciences & 44 & 36 & 7 & 21 & 131 & 10 & & \\
\hline W/Eet & 0 & $=0$ & 0 & 0 & & 0 & & \\
\hline Other Discipline & 8 & 5 & 3 & 3 & & 3 & & \\
\hline
\end{tabular}

$\mathrm{Pr}=\mathrm{Professor}$ AoP=Àssociate Professor AsP=Àssistant Professor I=Instructor $T=T e n u r e d ~ N T=N o n-$ tenured

Number of missing observations for Gender: 3 for Rank: 8 
Faculty research productivity 199

General Demographic Summary of Study Group

Research II Institutions

\begin{tabular}{lrrrrrrrrr} 
Variable & Number & Males & Females & Pr AoP AsP & I & T & NT \\
\multicolumn{1}{c}{ Totals } & 598 & 493 & 104 & 304 & 174 & 94 & 13 & 472 & 126 \\
& & & & & & & & \\
Agricul/Forest/Nat Res & 25 & 24 & 1 & 20 & 3 & 2 & 0 & 23 & 2 \\
Allied Health & 6 & 2 & 4 & 2 & 1 & 3 & 0 & 4 & 2 \\
Archit/Environ Design & 19 & 17 & 2 & 6 & 9 & 4 & 0 & 14 & 5 \\
Area/Ethnic Studies & 2 & 2 & 0 & 1 & 1 & 0 & 0 & 2 & 0 \\
Blological/Life Sci & 36 & 33 & 3 & 30 & 4 & 2 & 0 & 34 & 2 \\
Business/Management & 37 & 32 & 5 & 17 & 9 & 11 & 0 & 25 & 12 \\
Comunicatlons/Jour & 17 & 11 & 6 & 3 & 7 & 5 & 1 & 10 & 7 \\
Computer/Infor Sci & 11 & 10 & 1 & 6 & 2 & 3 & 0 & 8 & 3 \\
Economics & 18 & 14 & 4 & 7 & 6 & 5 & 0 & 13 & 5 \\
Education & 56 & 45 & 11 & 35 & 9 & 9 & 2 & 44 & 12 \\
Engineering & 46 & 45 & 1 & 25 & 10 & 9 & 1 & 31 & 15 \\
Fine Arts & 51 & 36 & 15 & 24 & 17 & 7 & 2 & 41 & 10 \\
Foreign Languages & 16 & 10 & 5 & 5 & 6 & 2 & 1 & 12 & 4 \\
Geography & 5 & 5 & 0 & 1 & 4 & 0 & 0 & 5 & 0 \\
Health Professions & 12 & 6 & 6 & 5 & 4 & 1 & 1 & 8 & 4 \\
Home Economics & 8 & 3 & 5 & 4 & 3 & 0 & 1 & 6 & 2 \\
Humanities & 53 & 41 & 12 & 21 & 24 & 5 & 0 & 45 & 8 \\
Industrial Arts & 1 & 1 & 0 & 0 & 1 & 0 & 0 & 1 & 0 \\
Law & 3 & 1 & 2 & 0 & 0 & 2 & 1 & 1 & 2 \\
Library Science & 1 & 1 & 0 & 0 & 1 & 0 & 0 & 1 & 0 \\
Matn/Statistics & 23 & 21 & 2 & 14 & 5 & 4 & 0 & 19 & 4 \\
Military Sci/Tech & 0 & 0 & 0 & 0 & 0 & 0 & 0 & 0 & 0 \\
Physical/Health Ed & 17 & 14 & 3 & 6 & 5 & 4 & 2 & 10 & 7 \\
Physical Sciences & 51 & 51 & 0 & 33 & 10 & 6 & 0 & 44 & 7 \\
Psychology & 18 & 15 & 3 & 10 & 6 & 2 & 0 & 15 & 3 \\
Public Affairs & 3 & 3 & 0 & 1 & 2 & 0 & 0 & 3 & 0 \\
Social Sciences & 48 & 38 & 10 & 21 & 19 & 7 & 1 & 41 & 7 \\
Voc/Tech Training & 0 & 0 & 0 & 0 & 0 & 0 & 0 & 0 & 0 \\
Other Discipline & 15 & 12 & 3 & 7 & 6 & 1 & 0 & 12 & 3 \\
& & & & & & & &
\end{tabular}

Pr=Professor AoP=Associate Professor AsP=Asssistant Professor I=Instructor $\mathrm{T}=$ Tenured $\mathrm{NT}=$ Non-tenured

Number of missing observations for Gender: 1 for Rank: 13 
Faculty research productivity 200

General Demographic Sunnary of Study Group

Doctorate I Institutions

Variable

Totals

Agricul/Forest/Nat Res

Allled Health

Archit/Environ Design

Àrea/Ethnic Studies

Biological/Life Sci

Business/Management

Communications/Jour

Computer/Infor Sci

Economics

Education

Engineering

Fine Arts

Foreign Languages

Geography

Health Professions

Home Economics

Humanities

Industrial Arts

Law

Library Science

Math/Statistics

Military Sci/Tech

Physical/Heal th Ed

Physical Sciences

Psychology

Public Affairs

Social Sciences

Voc/Tech Training

Other Discipline
Number Males Females Pr ÀoP AsP I I N N

$607 \quad 481 \quad 121 \quad 25019913515465141$

$\begin{array}{lllllllll}6 & 6 & 0 & 1 & 4 & 1 & 0 & 5 & 1\end{array}$

$\begin{array}{lllllllll}5 & 3 & 2 & 2 & 3 & 0 & 0 & 4 & 1\end{array}$

$\begin{array}{lllllllll}7 & 5 & 2 & 4 & 2 & 1 & 0 & 5 & 2\end{array}$

$\begin{array}{lllllllll}0 & 0 & 0 & 0 & 0 & 0 & 0 & 0 & 0\end{array}$

$\begin{array}{lllllllll}30 & 25 & 5 & 16 & 9 & 4 & 0 & 25 & 5\end{array}$

$\begin{array}{lllllllll}47 & 41 & 6 & 21 & 12 & 11 & 0 & 31 & 16\end{array}$

$\begin{array}{lllllllll}19 & 15 & 4 & 11 & 3 & 3 & 1 & 15 & 4\end{array}$

$\begin{array}{lllllllll}21 & 20 & 1 & 8 & 5 & 8 & 0 & 14 & 7\end{array}$

$\begin{array}{lllllllll}19 & 17 & 2 & 4 & 9 & 6 & 0 & 13 & 6\end{array}$

$\begin{array}{lllllllll}54 & 43 & 11 & 29 & 15 & 8 & 1 & 43 & 11\end{array}$

$\begin{array}{lllllllll}39 & 39 & 0 & 18 & 10 & 10 & 1 & 27 & 12\end{array}$

$\begin{array}{lllllllll}44 & 30 & 14 & 18 & 20 & 5 & 2 & 37 & 8\end{array}$

$\begin{array}{lllllllll}18 & 13 & 5 & 5 & 3 & 10 & 0 & 13 & 5\end{array}$

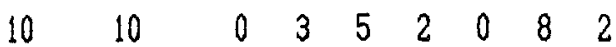

$\begin{array}{lllllllll}25 & 6 & 19 & 4 & 8 & 9 & 4 & 13 & 12\end{array}$

$\begin{array}{lllllllll}6 & 1 & 5 & 2 & 1 & 3 & 0 & 4 & 2\end{array}$

$\begin{array}{lllllllll}67 & 53 & 14 & 27 & 25 & 14 & 2 & 56 & 12\end{array}$

$\begin{array}{lllllllll}1 & 1 & 0 & 1 & 0 & 0 & 0 & 1 & 0\end{array}$

$\begin{array}{lllllllll}1 & 1 & 0 & 0 & 0 & 1 & 0 & 0 & 1\end{array}$

$\begin{array}{lllllllll}4 & 2 & 2 & 1 & 2 & 1 & 0 & 3 & 1\end{array}$

$\begin{array}{lllllllll}38 & 36 & 2 & 13 & 11 & 12 & 2 & 24 & 14\end{array}$

$\begin{array}{lllllllll}2 & 2 & 0 & 0 & 2 & 0 & 0 & 2 & 0\end{array}$

$\begin{array}{lllllllll}9 & 6 & 3 & 2 & 3 & 2 & 1 & 8 & 1\end{array}$

$\begin{array}{lllllllll}39 & 39 & 0 & 21 & 11 & 7 & 0 & 32 & 7\end{array}$

$\begin{array}{lllllllll}23 & 19 & 4 & 14 & 7 & 2 & 0 & 23 & 0\end{array}$

$\begin{array}{lllllllll}6 & 5 & 1 & 3 & 3 & 0 & 0 & 6 & 0\end{array}$

$\begin{array}{lllllllll}49 & 37 & 12 & 16 & 20 & 13 & 0 & 39 & 10\end{array}$

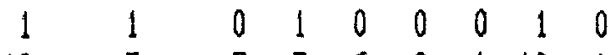

$12=5 \quad 7 \quad 5 \quad 6 \quad 2 \quad 1131$

$\operatorname{Pr}=$ Professor AoP=Associate Professor AsP=Assistant Professor I=Instructor $T=T$ Tenured NT=Non-tenured

Number of missing observations for Gender: 5 for Tenure Status: 1

for Rank: 8 
Faculty research productivity 201

General Demographic Sumnary of Study Group

Doctorate II Institutions

Variable

Number Males Females Pr AoP AsP I I NT

Totals

$\begin{array}{lllll}583 & 429 & 154 & 22719712118429 & 154\end{array}$

Agricul/Forest/Nat Res

Allied Health

Archit/Environ Design

Area/Ethnic Studies

Biological/Life Sci

Business/Management

Communications/Jour

Computer/Infor Scl

Economics

Education

Engineering

Fine Arts

Foreign Languages

Geography

Health Professions

Home Economics

Humanities

Industrial Arts

Law

Library Science

Math/Statistics

Military Sci/Tech

Physical/Heal th Ed

Physical Sciences

Psychology

Pubilc Affairs

Social Sciences

Voc/Tech Training

Other Discipline

$\begin{array}{rrrrrrrrr}12 & 11 & 1 & 7 & 5 & 0 & 0 & 10 & 2 \\ 5 & 4 & 1 & 2 & 1 & 2 & 0 & 3 & 2 \\ 2 & 2 & 0 & 0 & 1 & 1 & 0 & 0 & 2 \\ 1 & 1 & 0 & 0 & 1 & 0 & 0 & 0 & 1 \\ 23 & 20 & 3 & 12 & 9 & 1 & 1 & 17 & 6 \\ 43 & 35 & 8 & 16 & 8 & 14 & 2 & 27 & 16 \\ 18 & 12 & 6 & 4 & 7 & 7 & 0 & 10 & 8 \\ 17 & 15 & 2 & 4 & 7 & 4 & 0 & 10 & 7 \\ 6 & 5 & 1 & 1 & 2 & 2 & 0 & 4 & 2 \\ 35 & 24 & 11 & 11 & 17 & 6 & 0 & 29 & 6 \\ 45 & 45 & 0 & 17 & 16 & 11 & 0 & 29 & 16 \\ 40 & 30 & 10 & 15 & 18 & 4 & 0 & 35 & 5 \\ 24 & 17 & 7 & 7 & 8 & 7 & 1 & 18 & 6 \\ 6 & 6 & 0 & 0 & 5 & 1 & 0 & 5 & 1 \\ 28 & 8 & 20 & 7 & 10 & 9 & 1 & 16 & 12 \\ 9 & 2 & 7 & 4 & 2 & 1 & 1 & 6 & 3 \\ 74 & 57 & 17 & 29 & 27 & 15 & 1 & 56 & 18 \\ 2 & 2 & 0 & 0 & 1 & 1 & 0 & 1 & 1 \\ 1 & 1 & 0 & 0 & 0 & 0 & 0 & 0 & 1 \\ 0 & 0 & 0 & 0 & 0 & 0 & 0 & 0 & 0 \\ 28 & 25 & 3 & 10 & 10 & 8 & 0 & 25 & 3 \\ 0 & 0 & 0 & 0 & 0 & 0 & 0 & 0 & 0 \\ 18 & 13 & 5 & 4 & 4 & 4 & 5 & 10 & 8 \\ 49 & 48 & 1 & 28 & 12 & 9 & 0 & 40 & 9 \\ 29 & 21 & 8 & 15 & 8 & 6 & 0 & 23 & 6 \\ 3 & 3 & 0 & 2 & 0 & 1 & 0 & 3 & 0 \\ 45 & 37 & 8 & 26 & 13 & 5 & 1 & 38 & 8 \\ 7 & 6 & 1 & 1 & 0 & 1 & 5 & 4 & 3 \\ 12 & \approx 7 & 5 & 5 & 5 & 1 & 0 & 10 & 2\end{array}$

$\mathrm{Pr}=$ Professor AoP=Associate Professor AsP=Assistant Professor I=Instructor $T=$ Tenured NT=Non-tenured

Number of missing observations for Gender: 1 for Rank: 20 
Faculty research productivity 202

General Demographic Summary of Study Group

Comprehensive I Institutions

Variable

Totals

Agricul/Porest/Nat Res

Allied Health

Archit/Environ Design

Area/Pthnic Studies

Biological/Life Sci

Business/Hanagement

Communications/Jour

Computer/Infor Scl

Economics

Education

Engineering

Fine Arts

Foreign Languages

Geography

Health Professions

Home Economics

Humanities

Industrial Arts

Law

Library Science

Hath/Statistics

Military Sci/Tech

Physical/Health Ed

Physical Sciences

Psychology

Public Affairs

Social Sciences

Voc/Tech Training

other Discipline
Number Males Females Pr AoP AsP I $\quad$ T NT

$\begin{array}{llllllll}554 & 395 & 158 & 244 & 161 & 118 & 13 & 395158\end{array}$

$\begin{array}{rrrrrrrrr}7 & 3 & 4 & 6 & 0 & 1 & 0 & 5 & 2 \\ 2 & 0 & 2 & 0 & 1 & 1 & 0 & 2 & 0 \\ 0 & 0 & 0 & 0 & 0 & 0 & 0 & 0 & 0 \\ 1 & 1 & 0 & 1 & 0 & 0 & 0 & 1 & 0 \\ 22 & 16 & 6 & 15 & 3 & 4 & 0 & 15 & 7 \\ 58 & 46 & 12 & 17 & 21 & 18 & 1 & 32 & 26 \\ 23 & 17 & 6 & 10 & 2 & 7 & 3 & 14 & 9 \\ 9 & 7 & 2 & 3 & 3 & 2 & 0 & 6 & 3 \\ 9 & 8 & 1 & 5 & 2 & 2 & 0 & 8 & 1 \\ 51 & 30 & 21 & 23 & 18 & 9 & 0 & 34 & 17 \\ 24 & 23 & 1 & 8 & 8 & 7 & 0 & 13 & 11 \\ 47 & 31 & 16 & 18 & 17 & 9 & 0 & 35 & 12 \\ 19 & 11 & 8 & 9 & 2 & 7 & 0 & 14 & 5 \\ 6 & 6 & 0 & 3 & 2 & 1 & 0 & 6 & 0 \\ 20 & 0 & 20 & 4 & 6 & 7 & 1 & 9 & 11 \\ 6 & 1 & 5 & 0 & 4 & 2 & 0 & 4 & 2 \\ 77 & 59 & 18 & 47 & 18 & 9 & 3 & 61 & 16 \\ 3 & 2 & 1 & 3 & 0 & 0 & 0 & 3 & 0 \\ 0 & 0 & 0 & 0 & 0 & 0 & 0 & 0 & 0 \\ 1 & 1 & 0 & 0 & 0 & 1 & 0 & 1 & 0 \\ 22 & 17 & 5 & 8 & 8 & 4 & 0 & 19 & 3 \\ 0 & 0 & 0 & 0 & 0 & 0 & 0 & 0 & 0 \\ 25 & 18 & 7 & 6 & 7 & 7 & 3 & 14 & 11 \\ 43 & 35 & 8 & 23 & 12 & 5 & 0 & 33 & 10 \\ 26 & 22 & 3 & 12 & 9 & 5 & 0 & 22 & 4 \\ 2 & 2 & 0 & 1 & 1 & 0 & 0 & 1 & 1 \\ 43 & 34 & 9 & 21 & 15 & 6 & 1 & 38 & 5 \\ 4 & 2 & 2 & 0 & 1 & 3 & 0 & 2 & 2 \\ 4 & 3 & 1 & 1 & 1 & 1 & 1 & 3 & 1\end{array}$

Pr=Professor AoP=Associate Professor AsP=Assistant Professor I=Instructor $T=$ Tenured NT=Non-tenured

Number of missing observations for Gender: 1 for Rank: 18 
Faculty research productivity 203

General Demographic Sumnary of Study Group

Comprehensive II Institutions

\begin{tabular}{|c|c|c|c|c|c|c|c|c|}
\hline Variable & Number & Males & Females & & AOP & $P$ & & $\mathrm{~T} \mathrm{NT}$ \\
\hline Totals & 516 & 329 & 185 & & 157 & 140 & & 347169 \\
\hline Agricul/Forest/Nat Res & 2 & 2 & 0 & 1 & 1 & 0 & 0 & 2 \\
\hline Allied Health & 4 & 1 & 3 & 1 & 1 & 2 & 0 & 3 \\
\hline Archit/Environ Design & 0 & 0 & 0 & 0 & 0 & 0 & 0 & 0 \\
\hline Area/Ethnic Studies & 0 & 0 & 0 & 0 & 0 & 0 & 0 & \\
\hline Biological/Life Sci & 34 & 27 & 7 & 16 & 14 & 4 & 0 & 2410 \\
\hline Business/Management & 42 & 37 & 5 & 9 & 15 & 17 & 1 & 1923 \\
\hline Commun ications/Jour & 16 & 9 & 7 & 6 & 5 & 4 & 1 & 106 \\
\hline Computer/Infor Sci & 11 & 8 & 3 & 1 & 3 & 6 & 1 & 4 \\
\hline Economics & 10 & 7 & 3 & 3 & 6 & 1 & 0 & 82 \\
\hline Education & 37 & 15 & 22 & 12 & 9 & 11 & 5 & 2413 \\
\hline Engineering & 1 & 1 & 0 & 0 & 1 & 0 & 0 & 10 \\
\hline Fine Arts & 61 & 44 & 17 & 18 & 20 & 16 & 6 & 4021 \\
\hline Languages & 22 & 12 & 10 & 10 & 6 & 5 & 1 & 157 \\
\hline Geography & 2 & 1 & 1 & 1 & 0 & 1 & 0 & 11 \\
\hline rofessions & 29 & 1 & 27 & 4 & 4 & 17 & 4 & 1712 \\
\hline Home Economics & 3 & 1 & 2 & 0 & 1 & 1 & 1 & 12 \\
\hline Humanities & 98 & 66 & 32 & 44 & 29 & 19 & 5 & 742 \\
\hline Industrial Arts & 2 & 2 & 0 & 1 & 1 & 0 & 0 & 20 \\
\hline Law & 1 & 1 & 0 & 1 & 0 & 0 & 0 & 01 \\
\hline Library Science & 1 & 0 & 1 & 0 & 1 & 0 & 0 & \\
\hline Math/Statistics & 20 & 14 & 6 & 10 & 6 & & 1 & 164 \\
\hline $\mathrm{Scl} / \mathrm{Tecl}$ & 0 & 0 & 0 & 0 & 0 & 0 & 0 & \\
\hline Physical/Health Ed & 21 & 14 & 7 & 5 & 9 & & 2 & 16 \\
\hline Physical Sciences & 23 & 19 & 4 & 11 & 5 & & 0 & 178 \\
\hline Psychology & 24 & 15 & 8 & 12 & 7 & 4 & 1 & 17 \\
\hline Public Aftairs & 0 & 0 & 0 & 0 & 0 & 0 & 0 & \\
\hline Social Sciences & 39 & 26 & 13 & 16 & 11 & 12 & 0 & 2910 \\
\hline Voc/Tech Training & 1 & 1 & 0 & 0 & 0 & & 0 & \\
\hline Other Discipline & 12 & 5 & 7 & 4 & 2 & & 1 & \\
\hline
\end{tabular}

Pr=Professor AoP=Associate Professor AsP=Assistant Professor I=Instructor $T=$ Tenured NT=Non-tenured

Number of missing observations for Gender: 2 for Rank: 3 
Faculty research productivity 204

General Demographic Summary of Study Group

Liberal Arts I Institutions

Variable

Number Males Females Pr AoP AsP I T NT

Totals

$\begin{array}{lllllllll}592 & 407 & 183 & 248 & 166 & 142 & 20 & 411 & 181\end{array}$

Agricul/Forest/Nat Res

Allied Health

Archit/Environ Design

Area/Ethnic Studies

Biological/Life Sci

Business/Management

Commun I cati ons/Jour

Computer/Infor Scl

Economics

Education

Engineering

Eine Arts

Foreign Languages

Geography

Health Professions

Home Economics

Humanities

Industrial Arts

Law

Library Science

Nath/Statistics

Military Sci/Tech

Physical/Health Ed

Physical Sciences

Psychology

Public Aftairs

Social Sciences

Voc/Tech Training

other Discipline

$\begin{array}{rrrrrrrrr}0 & 0 & 0 & 0 & 0 & 0 & 0 & 0 & 0 \\ 0 & 0 & 0 & 0 & 0 & 0 & 0 & 0 & 0 \\ 1 & 1 & 0 & 0 & 1 & 0 & 0 & 1 & 1 \\ 1 & 1 & 0 & 1 & 0 & 0 & 0 & 1 & 0 \\ 31 & 22 & 9 & 9 & 13 & 9 & 0 & 21 & 10 \\ 6 & 5 & 1 & 2 & 3 & 1 & 0 & 2 & 4 \\ 6 & 4 & 2 & 0 & 1 & 5 & 0 & 3 & 3 \\ 8 & 6 & 1 & 2 & 2 & 4 & 0 & 6 & 2 \\ 37 & 32 & 5 & 18 & 9 & 9 & 1 & 26 & 11 \\ 18 & 11 & 7 & 7 & 6 & 5 & 0 & 11 & 7 \\ 13 & 12 & 1 & 8 & 4 & 1 & 0 & 8 & 5 \\ 56 & 35 & 21 & 17 & 22 & 9 & 3 & 38 & 18 \\ 60 & 27 & 33 & 25 & 16 & 15 & 4 & 43 & 17 \\ 2 & 1 & 1 & 1 & 0 & 1 & 0 & 1 & 1 \\ 10 & 0 & 10 & 1 & 2 & 7 & 0 & 4 & 6 \\ 1 & 0 & 1 & 0 & 0 & 0 & 1 & 0 & 1 \\ 127 & 87 & 40 & 65 & 28 & 27 & 3 & 96 & 31 \\ 0 & 0 & 0 & 0 & 0 & 0 & 0 & 0 & 0 \\ 0 & 0 & 0 & 0 & 0 & 0 & 0 & 0 & 0 \\ 0 & 0 & 0 & 0 & 0 & 0 & 0 & 0 & 0 \\ 33 & 25 & 8 & 18 & 7 & 7 & 0 & 24 & 9 \\ 0 & 0 & 0 & 0 & 0 & 0 & 0 & 0 & 0 \\ 28 & 18 & 10 & 5 & 6 & 8 & 6 & 14 & 14 \\ 57 & 52 & 5 & 26 & 12 & 17 & 1 & 37 & 20 \\ 42 & 30 & 12 & 18 & 14 & 8 & 1 & 31 & 11 \\ 0 & 0 & 0 & 0 & 0 & 0 & 0 & 0 & 0 \\ 51 & 35 & 16 & 21 & 20 & 9 & 0 & 40 & 11 \\ 0 & 0 & 0 & 0 & 0 & 0 & 0 & 0 & 0 \\ 4 & 3 & 0 & 4 & 0 & 0 & 0 & 4 & 0 \\ 1 & 2 & & & & & & & \end{array}$

Pr=Professor AoP=Associate Professor AsP=Asssistant Professor I=Instructor $\mathrm{T}=$ Tenured $\mathrm{NT}=$ Non-tenured

Number of missing observations for Gender: 2 for Rank: 16 
Faculty research productivity 205

General Demographic Sumnary of Study Group

Liberal Arts II Institutions

Variable

Number Males Females Pr AoP AsP I T NT

Totals

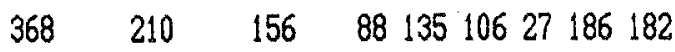

Agricul/Forest/Nat Res

Allied Heal th

Archit/Environ Design

Area/Ethnic Studies

Biological/Life Sci

Business/Management

Communications/Jour

Computer/Infor Scl

Economics

Education

Engineering

Fine Arts

Foreign Languages

Geography

Health Professions

Home Economics

Humanities

Industrial Arts

Law

Library Science

Math/Statistics

Military Sci/Tech

Physical//lealth Ed

$\begin{array}{rrrrrrrrr}1 & 0 & 1 & 0 & 0 & 0 & 1 & 0 & 1 \\ 1 & 1 & 0 & 0 & 0 & 0 & 1 & 0 & 1 \\ 1 & 0 & 1 & 0 & 0 & 1 & 0 & 0 & 1 \\ 0 & 0 & 0 & 0 & 0 & 0 & 0 & 0 & 0 \\ 22 & 19 & 3 & 8 & 10 & 4 & 0 & 16 & 6 \\ 24 & 18 & 6 & 4 & 12 & 5 & 2 & 7 & 17 \\ 9 & 6 & 3 & 4 & 1 & 3 & 1 & 3 & 6 \\ 5 & 4 & 1 & 0 & 1 & 3 & 1 & 1 & 4 \\ 3 & 2 & 1 & 0 & 1 & 2 & 0 & 2 & 1 \\ 36 & 11 & 24 & 7 & 16 & 12 & 1 & 18 & 18 \\ 0 & 0 & 0 & 0 & 0 & 0 & 0 & 0 & 0 \\ 54 & 31 & 23 & 7 & 19 & 17 & 5 & 27 & 27 \\ 16 & 5 & 11 & 3 & 7 & 4 & 2 & 7 & 9 \\ 2 & 2 & 0 & 0 & 1 & 1 & 0 & 1 & 1 \\ 16 & 0 & 16 & 0 & 7 & 6 & 3 & 4 & 12 \\ 7 & 0 & 7 & 2 & 2 & 3 & 0 & 2 & 5 \\ 69 & 50 & 19 & 25 & 28 & 12 & 1 & 46 & 23 \\ 0 & 0 & 0 & 0 & 0 & 0 & 0 & 0 & 0 \\ 0 & 0 & 0 & 0 & 0 & 0 & 0 & 0 & 0 \\ 2 & 0 & 2 & 1 & 0 & 1 & 0 & 1 & 1 \\ 20 & 13 & 7 & 4 & 6 & 8 & 2 & 6 & 14 \\ 0 & 0 & 0 & 0 & 0 & 0 & 0 & 0 & 0 \\ 15 & 11 & 4 & 1 & 3 & 9 & 1 & 9 & 6 \\ 23 & 14 & 9 & 7 & 9 & 5 & 2 & 12 & 11 \\ 20 & 12 & 7 & 8 & 6 & 6 & 0 & 13 & 7 \\ 0 & 0 & 0 & 0 & 0 & 0 & 0 & 0 & 0 \\ 18 & 10 & 8 & 7 & 6 & 4 & 1 & 11 & 7 \\ 0 & 0 & 0 & 0 & 0 & 0 & 0 & 0 & 0 \\ 4 & 1 & 3 & 0 & 0 & 0 & 3 & 0 & 4\end{array}$

$\mathrm{Pr}=$ Professor AoP=Associate Professor AsP=Àssistant Professor I=Instructor $T=$ Tenured NT=Non-tenured

Number of missing observations for Gender: 2 for Rank: 12 